NBER WORKING PAPER SERIES

\title{
INSTITUTIONAL CAUSES, MACROECONOMIC SYMPTOMS: VOLATILITY, CRISES AND GROWTH
}

\author{
Daron Acemoglu \\ Simon Johnson \\ James Robinson \\ Yunyong Thaicharoen \\ Working Paper 9124 \\ http://www.nber.org/papers/w9124
NATIONAL BUREAU OF ECONOMIC RESEARCH
1050 Massachusetts Avenue
Cambridge, MA 02138 \\ September 2002
}

We thank Alessandra Fogli, Sebastián Mazzuca, Ragnar Torvik and seminar participants at the CarnegieRochester conference, NYU and MIT for their suggestions. The views expressed herein are those of the authors and not necessarily those of the National Bureau of Economic Research.

(C) 2002 by Daron Acemoglu, Simon Johnson, James Robinson and Yunyong Thaicharoen. All rights reserved. Short sections of text, not to exceed two paragraphs, may be quoted without explicit permission provided that full credit, including $\odot$ notice, is given to the source. 
Institutional Causes, Macroeconomic Symptoms:

Volatility, Crises and Growth

Daron Acemoglu, Simon Johnson, James Robinson

and Yunyong Thaicharoen

NBER Working Paper No. 9124

September 2002

JEL No. O11, E30, N10

\section{$\underline{\text { ABSTRACT }}$}

Countries that have pursued distortionary macroeconomic policies, including high inflation, large budget deficits and misaligned exchange rates, appear to have suffered more macroeconomic volatility and also grown more slowly during the postwar period. Does this reflect the causal effect of these macroeconomic policies on economic outcomes? One reason to suspect that the answer may be no is that countries pursuing poor macroeconomic policies also have weak "institutions," including political institutions that do not constrain politicians and political elites, ineffective enforcement of property rights for investors, widespread corruption, and a high degree of political instability.

This paper documents that countries that inherited more "extractive" institutions from their colonial past were more likely to experience high volatility and economic crises during the postwar period. More specifically, societies where European colonists faced high mortality rates more than 100 years ago are much more volatile and prone to crises. Based on our previous work, we interpret this relationship as due to the causal effect of institutions on economic outcomes: Europeans did not settle and were more likely to set up extractive institutions in areas where they faced high mortality. Once we control for the effect of institutions, macroeconomic policies appear to have only a minor impact on volatility and crises. This suggests that distortionary macroeconomic policies are more likely to be symptoms of underlying institutional problems rather than the main causes of economic volatility, and also that the effects of institutional differences on volatility do not appear to be primarily mediated by any of the standard macroeconomic variables. Instead, it appears that weak institutions cause volatility through a number of microeconomic, as well as macroeconomic, channels.

Daron Acemoglu

Department of Economics

MIT, E52-380B

50 Memorial Drive

Cambridge, MA 02142

and NBER

daron@mit.edu

James Robinson

Department of Political Science and Economis

Berkeley

jamesar@socrates.berkeley.edu
Simon Johnson

Sloan School of Management

MIT

50 Memorial Drive

Cambridge, MA 02142

sjohnson@mit.edu

Yunyong Thaicharoen

Bank of Thailand

Thailand 


\section{INTRODUCTION}

The postwar experience of many societies in Africa, Central and South America and elsewhere has been marred by severe crises and substantial volatility. Why some societies suffer from large volatility and crises is one of the central questions facing macroeconomics. The Washington consensus highlighted a variety of factors as primary causes of bad macroeconomic performance and volatility, including poorly enforced property rights and corruption, but the emphasis was often placed on mismanaged macroeconomic policies. ${ }^{1}$ Policies often blamed for crises and poor macroeconomic performance include excessive government spending, high inflation, and overvalued exchange rates. Similarly, in most macroeconomic accounts of economic and financial crises, the blame is often laid on distortionary macroeconomic policies. A salient example would be the recent crisis in Argentina, where, according to many macroeconomists, an overvalued exchange rate was the cause of the macroeconomic problems. Another example is chronic volatility in Ghana, especially from independence until the early 1980s. Ghana had a relatively high inflation $(1970-98$ average $=39.1$ percent $)$ and one of the most overvalued exchange rates in our sample. It also experienced substantial crises and volatility (the standard deviation of the annual growth rate, 1970-97, was approximately 5, as compared to, for example, an average of 2.5 among West European countries). In Ghana, as in Argentina, it is easy to blame macroeconomic policies for macroeconomic problems.

Distortionary macroeconomic policies are not typically chosen because politicians believe that high inflation or overvalued exchange rates are good for economic performance. Instead, they reflect underlying institutional problems in these countries. For example, in his classic account of political economy in Africa, Robert Bates (1981) emphasized how overvalued exchange rates were in effect a way of transferring resources

\footnotetext{
${ }^{1}$ See for example Williamson (1990). This is also the line generally taken by the IMF and the World Bank. For example, Edwards (1989) analyzes the 34 IMF programs with high-conditionality between 1983 and 1985, and provides a breakdown of the conditions/policy requirements. Four of the five most common conditions required by the IMF are: control of credit to public sector, control of money aggregates, devaluation and control of public expenditures.
} 
from the large agricultural sector to urban interests, and developed the argument that this reflected the power of urban interests to influence the decisions of politicians in an "institutionally-weak" society. In fact, Ghana is a textbook case of highly distortionary redistribution, political instability, and politician after politician being captured by interest groups or pursuing distortionary policies in order to remain in power.

This perspective raises the possibility that the macroeconomic performance of many of these societies may reflect not only, or not even primarily, the effect of distortionary macroeconomic policies, but the deep institutional causes leading to these particular macroeconomic policies. In other words, one may suspect that in the Ghanaian example, even without the overvalued exchange rate, macroeconomic performance would have been volatile because with the institutions and the social structure Ghana inherited from the British colonists, there was no way of constraining politicians, ensuring adequate enforcement of contracts and property rights, and preventing various social groups from engaging in chronic political fights to take control of the society's resources. Through one channel or another, the major producers in Ghana, the cocoa farmers, were going to be expropriated by the politicians and urban interests. Overvalued exchange rates were simply one of the ways of expropriating the producers. Moreover, given the weak constraints on politicians and political elites, there were substantial gains to be had from political power, and these gains created considerable political and economic instability in Ghana, as different groups fought to achieve and retain power.

The main result of this paper is to document a strong and robust relationship between the historically-determined component of postwar institutions and volatility (as well as severity of economic crises and economic growth): countries that inherited worse ("extractive") institutions from European colonial powers are much more likely to experience high volatility and severe economic crises.

To document this relationship, we build on our previous work, Acemoglu, Johnson, and Robinson (2001), and develop an instrument for the historically-determined component of institutions in a cross-section of countries. More specifically, we exploit 
differences in mortality rates faced by European settlers during colonial times as a source of variation in the historical development of institutions among former colonies. Former European colonies provide an attractive sample to study the effect of institutions on economic outcomes; European colonization of a large part of the globe starting in the 15th century comes close to a "natural experiment" in creating different institutions, since the institutions in these countries were largely shaped by European colonization, and there were systematic differences in institutions that Europeans set up in various colonies. In places where colonists faced high mortality rates, they followed a different colonization strategy, with more extractive institutions, while they were more likely to set up institutions protecting private property and encouraging investments in areas where they settled. In Acemoglu, Johnson, and Robinson (2001), we illustrated and developed the argument that (potential) European settler mortality rates are a good instrument for the institutional development of these countries throughout the nineteenth and twentieth centuries, and via this channel, for their current institutions. We also showed a large effect of institutions on long-run economic development.

Figure 1 shows that there is also a strong relationship between settler mortality rates and postwar economic outcomes, especially volatility and crises. Former colonies with higher European mortality more than 100 years ago are today more likely to suffer high volatility (as measured by the standard deviation of growth rate), severe output collapses (as measured by the largest output drop in any year) and low growth. Our interpretation is that these relationships reflect the causal effect of institutions on volatility and other economic outcomes: in places where the Europeans did not settle, they set up more extractive institutions with power concentrated in the hands of a small elite, and these countries typically ended up with weaker (worse) institutions at the beginning of the postwar era. And institutionally-weak societies not only grow less slowly in the long run (Acemoglu, Johnson and Robinson, 2001, 2002a), but also experience greater volatility and other worse macroeconomic outcomes.

The relationships shown in Figure 1, especially those involving volatility and crises, 
are highly robust and account for a large fraction of differences in these economic outcomes across countries. ${ }^{2}$ Moreover, once we control for the effect of institutions on economic outcomes in this manner, standard macroeconomic variables, often blamed for economic crises and volatility, play a relatively minor role. This suggests that macroeconomic policies are not the major cause of crises, and are more likely symptoms of underlying institutional problems. Somewhat more surprisingly, these macroeconomic variables, with the possible exception of exchange rate misalignment, do not appear to be a major mediating channel through which institutions affect economic outcomes. Weak institutions appear to create macroeconomic problems via a variety of microeconomic as well as macroeconomic channels.

What are the institutions that matter? In our empirical exercise, we use an institutional variable for which we have data for a broad cross-section of countries at the beginning of the sample: constraints placed on the executive, as measured in the Polity IV data set based on the work of Robert Gurr. This variable is conceptually attractive since it measures institutional and other constraints that are placed on presidents and dictators (or monarchies). Theoretically, we expect a society where elites and politicians are effectively constrained to experience less infighting between various groups to take control of the state, and to pursue more sustainable policies. Nevertheless, "constraint on the executive" is only one measure of institutions, and it is quite possible that a country might have adequate constraints on their executives, but suffer from corruption or weak property rights for other reasons. More generally, the institutions we are interested in are a cluster of social arrangements that include constitutional and social limits on politicians' and elites' power, the rule of law, provisions for mediating social cleavages, strong property rights enforcement, a minimum amount of equal opportunity and relatively broad-based access to education, etc. This cluster determines whether agents with the investment opportunities will undertake these investments, whether there will be significant swings in the political and social environment leading to crises,

\footnotetext{
${ }^{2}$ Figure 1A excludes two outliers, Gabon and Rwanda, to show the pattern more clearly. Including these two countries slightly strengthens the relationship.
} 
and whether politicians will be induced to pursue unsustainable policies in order to remain in power in the face of deep social cleavages. Therefore, we prefer to be relatively loose on what the fundamental institutional problems are, and instead try to isolate the historically-determined component of these institutional differences.

How do we interpret these results? Our conclusion is that the large postwar crosscountry differences in volatility, crises and growth performance have institutional causes. Both poor macroeconomic performance and distortionary macroeconomic policies are symptoms rather than causes, and the macroeconomic policies often blamed for crises do not appear to be the major mediating channel for the impact of institutions on economic instability. This does not mean that macroeconomic policies do not matter for macroeconomic outcomes. Clearly, overvalued exchange rates or high inflation would discourage certain investments, and unsustainable policies will necessarily lead to some sort of crisis. ${ }^{3}$ Our main argument is that in institutionally-weak societies, elites and politicians will find various ways of expropriating different segments of the society, ranging from microeconomic to various macroeconomic policies. It is the presence of this type of expropriation and the power struggle to control the state to take advantage of the resulting rents that underlie bad macroeconomic outcomes and volatility. ${ }^{4} \mathrm{~A}$ logical implication of this view is a seesaw effect: if the elites are prevented from using one particular instrument, as long as institutional weaknesses remain, a likely outcome is

\footnotetext{
${ }^{3}$ Moreover, the cause of the decline in U.S. output volatility over the past two decades is unlikely to be institutional. Our focus here is not differences in output volatility between OECD countries, which all have relatively good institutions, but the large cross-country differences in volatility across societies with very different institutional structures.

${ }^{4}$ There are a variety of reasons why weak constraints on executives and other institutional problems might lead to volatility. For example, Acemoglu and Robinson (2001) show how "weak institutions" might encourage coups and revolutions, leading to political and economic instability. Alternatively, institutional failures may also make economic adjustment difficult. In an important paper, Rodrik (1999) suggests that countries with weak institutions are unable to deal with major economic shocks, and identifies the major shocks with those taking place during the 1970s. Rodrik suggests that this inability to deal with global economic changes underlies the disappointing growth performance of many less developed countries (LDCs) during the 1980s and 1990s (see also Easterly, 2001). Similarly, Johnson, Boone, Breach and Friedman (2000) show that among emerging markets open to capital flows, it was those with weaker political and financial institutions that experienced more severe crises during the late 1990s, suggesting an important interaction between global shocks and institutions (see also Eichengreen and Bordo 2002).
} 
that they will pursue their objectives using other instruments. And this, we believe, is the reason why none of the standard macroeconomic variables are the main mediating channel for the effect of institutions on volatility and crises.

To improve our understanding of the relationship between institutions and volatility, we also look at whether countries with weak institutions are unable to deal with global crises, world economic slowdowns or other global developments, such as the increase in the volume of international trade. Our results indicate that this is not an important channel via which weak institutions affect volatility and economic performance. We also find that there is a very similar relationship between institutions and volatility in every decade, and crises are spread across the various decades quite evenly.

These findings suggest that it is the inability of institutionally-weak societies to deal with their own economic and political shocks that is of first-order importance. Moreover, this inability appears to be somewhat linked to "state failures" (civil wars, revolutions or periods of severe infighting). If we consider these state failures as the tip of the iceberg, it is a reasonable conjecture that many economic crises and a great deal of volatility happen amidst political problems. At some level, this is not surprising. The problem of institutionally-weak societies is to constrain those controlling political power, and this lack of constraints on politicians and elites increases the willingness of various groups to fight in order to gain power, and enables them to exploit their position, sometimes with disastrous consequences, when they come to power. Nevertheless, that the greater instability faced by institutionally-weak societies is linked to frequent political crises is for now only a conjecture, backed only with some circumstantial evidence.

There is now a large literature on economic volatility. Much of it focuses on developed countries, and investigates why the business cycle has become less volatile in the U.S. and many OECD economies over the past 20 years (e.g., Blanchard and Simon, 2001; McConnell and Perez-Quiros, 2000; Stock and Watson, 2002). This literature emphasizes technological factors (e.g., improved inventory management) and improvements in policy (e.g., better and more credible monetary policy, inflation targeting etc.). Our results 
can be interpreted as showing that these factors are much less important in the very large cross-country differences in volatility than are institutional differences.

The literature on macroeconomic volatility among LDCs is also large, but focuses primarily on macroeconomic problems (e.g., Krugman, 1979, Dornbusch et al., 1995; Kaminsky and Reinhart, 1999) and financial factors (e.g., Caballero, 2001; Caballero and Krishnamurthy, 2000; Chang and Valesco, 2002; Denizer et al., 2001; Easterly, Islam and Stiglitz, 2000, Voth, 2002, Raddatz, 2002). We are unaware of any studies linking volatility to long-run institutional causes other than the paper by Rodrik (2000) which shows that democracies are less volatile than nondemocratic regimes. In addition, Acemoglu and Zilibotti (1997) show a strong relationship between initial income and volatility: richer countries are less volatile. They interpret this as resulting from the fact that richer countries are able to achieve a more balanced sectoral distribution of output. Ramey and Ramey (1995) document a cross-country relationship between volatility and growth, and interpret it as due to the adverse effects of volatility on growth. Finally, Kraay and Ventura (2000) develop a model where trade between rich and poor countries can increase volatility in poor countries, and provide some evidence consistent with this prediction.

In addition, our work relates to the large literature on the determinants of growth. Starting with the seminal work by Barro (1991), many economists have found a variety of important determinants of growth. While some of these determinants are outcomes of previous investments, such as education, others are contemporary policy variables, such as government consumption or inflation. Although economic growth is not our main focus, our paper is clearly related to this literature since we are trying to determine which of these macroeconomic policies matter for volatility and crises (and also for growth), when we take the importance of institutions into account.

Finally, this paper is most closely related to studies investigating the relationship between institutions and economic performance. Many economists and social scientists have argued that economic and political institutions are a major determinant of economic 
outcomes. Recent proponents of this view include, among others, Jones (1981), North and Thomas (1973), North (1981), and Olson (1981) - see also Acemoglu and Robinson (2000, 2002), Bardhan (1984), Benhabib and Rustichini (1996), Krusell and Rios-Rull (1996), Parente and Prescott (1999) and Tornell and Velasco (1992) for attempts to model some of these issues. Acemoglu, Johnson and Robinson (2001 2002), Besley (1995), Johnson, McMillan and Woodruff (2002), Hall and Jones (1999), La Porta, Lopez-de-Silanes, Shleifer and Vishny (1998) and Mauro (1995), among others, provide micro and macro evidence consistent with this notion. All of these studies focus on the effect of institutions on economic growth, investment or the level of development. The current paper can be viewed as extending this literature by showing a robust and strong effect of institutions on the volatility of economic activity.

The rest of the paper is organized as follows. In the next section, we document the correlation between a range of macroeconomic variables and volatility, which is consistent with the standard view that macroeconomic policies have a causal effect on volatility. In Section 3, we discuss why we expect a relationship between institutions and volatility, and present two case studies, Argentina and Ghana, where institutional weaknesses appear to have translated into macroeconomic problems. In Section 4, we explain our empirical strategy for distinguishing the effect of institutions on volatility, crises and growth from the effect of macroeconomic policies. In Section 5, we review the source of variation in institutions that we will exploit for this exercise. In Section 6, we document the relationship between institutions and macroeconomic performance, and show how once we control for the causal effect of institutions (or of the historically-determined component of institutions) on volatility and economic performance, macroeconomic policies do not appear to play a direct role. In Section 7, we investigate the robustness of the effect of institutions on volatility, crises and growth, and explore various mechanisms via which this effect might be working. Section 8 concludes. 


\section{Macroeconomic Policies and Economic Performance}

The standard macroeconomic view links economic volatility to bad macroeconomic policies. According to this view, large government sectors and budget deficits, high inflation, and misaligned exchange rates will result in macroeconomic crises. In line with this standard view, many macroeconomists see a causal relationship between the improved conduct of monetary policy of the past two decades and the increased stability of U.S. output. Are there grounds to suspect that there is also a relationship between cross-country differences in volatility and macroeconomic policies? Again, the standard view among macroeconomists seems to be that the answer is yes. For example, in its 1987 Development Report, the World Bank states that "high inflation increases uncertainty, discourages investment and technological change, distorts relative prices, and stands in the way of sustainable growth." In discussing crises in Mexico and Argentina, Dornbusch et al. (1995, p. 220) write: “...the real exchange it is a key relative price. When it becomes too high, it hurts growth, endangers financial stability, and ultimately comes crashing down... the real exchange is in many, though not all, instances a policy variable..."

To investigate the relationship between macroeconomic policies and volatility, we construct a simple measure of cross-country differences in volatility; the standard deviation of the growth rate of per capita output. Our baseline period is 1970-97, but we also look separately at different decades. We take 1970 as the first year because of data availability reasons, and also because when we look at institutions, we want to start from a point in time when all the countries in our sample are independent nations (not colonies). In addition to volatility, we want to look at a measure of "severe crises"; with this purpose, we also calculate the largest drop in output for every country for 1970-97 (or for subperiods) as a proxy for the severity of the most important crisis. Finally, we also look at average growth as a measure of overall economic performance. Appendix Table A2 gives means and standard deviations for these variables in various subsamples, as well as descriptive statistics for some of the other variables we use in this paper. 
We have experimented with many different measures of macroeconomic policies. In this section, we report results using three different measures that appear to work best (i.e., they have the most robust effect on our measures of economic performance and volatility). These are average size of government (measured by government consumption to GDP ratio), (log) average rate of inflation, and a measure of exchange rate overvaluation, all of these calculated over the relevant periods. Average size of government is used as a proxy for "irresponsible" fiscal policy (we chose this variable rather than a measure of budget deficits, since it appears to work better than budget deficits, so gives a better chance for this macro policy variable to matter against institutions). High inflation is often viewed as a prime cause of volatility and poor economic performance. Overvalued exchange rates are often unsustainable, and naturally lead to economic crises. ${ }^{5}$

Figures 2, 3 and 4 show the bivariate relationship between these macroeconomic variables, on the one hand, and economic volatility (standard deviation of growth), crises (worst output drop) and growth, on the other. In all cases, we see the expected relationship. Countries with large government sectors are more volatile and have more severe crises. They also grow, on average, more slowly. The same is true for countries with high inflation and overvalued exchange rates.

Do these correlations reflect the causal effect of bad macroeconomic policies on economic volatility and performance or are they capturing the effect of institutional factors on economic outcomes? This is the question we investigate in the next four sections.

\footnotetext{
${ }^{5}$ These variables refer to the following dates and are obtained from the following sources: government consumption, from 1970 to 1989, obtained from Barro and Lee (1993) data set; and average inflation for 1970-1998, from World Development Indicators, CD-ROM, 1999. Real exchange rate overvaluation is for 1960-98, from Easterly and Levine (2002) who extend Dollar's (1992) data. Appendix Table A1 gives further details on data sources. We have also experimented with other macroeconomic variables, including volatility of exchange rate, size of government budget deficit, black market premia, etc.. These variables have less robust effects on economic instability, and we obtain very similar results to those reported below when we use these variables as well.
} 


\section{Institutions and Economic Performance}

Figures 2, 3 and 4 show a correlation between macroeconomic policies and outcomes, but they do not establish causality. Countries that pursue distortionary macroeconomic policies are different in a number of dimensions; most importantly, they differ substantially in their "social organization". While some countries, such as the U.S., Australia or Canada, are democratic, relatively equal, suffer few radical social cleavages and have a variety of checks and balances on politicians' actions, others, such as Ghana, Nicaragua, or Nigeria, fluctuate between democracy and dictatorship, are highly unequal, and lack effective constraints on politicians and elites. We refer to this cluster of social arrangements as "institutions" and think of the latter group of countries as having "weak institutions".

It is quite reasonable to suspect that weak institutions will have a significant impact on economic performance. In previous research, we documented a large effect of this type of institutions on economic development (Acemoglu, Johnson and Robinson, 2001, 2002a; see also Knack and Keefer, 1995, Hall and Jones, 1999). There are also natural reasons for why institutionally-weak countries might suffer substantial volatility, which we discuss next.

\subsection{Institutions and Volatility: Some Theoretical Ideas}

Here we briefly discuss why we might expect greater economic instability in institutionallyweak societies. ${ }^{6}$

1. In institutionally-weak societies there are few constraints on rulers. Following a change in the balance of political power, groups that gain politically may then attempt to use their new power to redistribute assets and income to themselves, in the process creating economic turbulence. In contrast, this source of turbulence would be largely absent in societies where institutions prevent this type of

\footnotetext{
${ }^{6}$ See the previous version of the paper where we provide a simple dynamic model formalizing the first two ideas.
} 
redistribution.

2. Lack of effective constraints on politicians and politically powerful groups implies that there are greater gains from coming to power, and correspondingly, greater losses from not controlling political power-thus, overall greater "political stakes". Therefore, in institutionally-weak societies, there will be greater infighting between various groups to come to power and enjoy these greater gains, and hence, greater political and economic turbulence.

3. With weak institutions, economic cooperation may have to rely on "trust" or, more explicitly, on cooperation supported by repeated games strategies. Shocks may make it impossible to sustain cooperation, and lead to output collapses.

4. With weak institutions, contractual arrangements will be more imperfect, making certain economic relationships more susceptible to shocks.

5. In societies with institutional problems, politicians may be forced to pursue unsustainable policies in order to satisfy various groups and remain in power, and volatility may result when these policies are abandoned.

6. With weak institutions, entrepreneurs may choose sectors/activities from which they can withdraw their capital more quickly, thus contributing to potential economic instability.

Our empirical work will not be able to distinguish between these various channels linking institutions to economic instability, though we believe that gaining a deeper understanding of the relative importance of various channels would be a major contribution to our understanding. We leave this as a potential area for future research. 


\subsection{Sources of Volatility in Institutionally-Weak Societies: Two Case STUDIES}

In this subsection, we briefly discuss the experiences of two institutionally-weak societies with economic instability, Argentina and Ghana.

\subsubsection{Ghana}

Ghana was the first European colony in Africa to become independent in 1958 and at this time had roughly the same level of GDP per capita as South Korea. However, in 2000 GDP per capita had just about recovered to where it was in 1958 even after a decade and a half of relatively consistent of growth. The economic and political history of Ghana has been marred by severe instability with military coups in 1966, 1972, 1978, 1979 and 1982 and re-democratizations in 1969, 1979 and 1996.

The anti-colonial movement was organized in Ghana by Kwame Nkrumah and his Convention People's Party (CPP) (see Austin, 1964, and Apter, 1972). However, as soon as the promise of independence had been secured from the British the anti-colonial coalition in Ghana crumbled. Chazan and Pellow note (1986, p. 30) "by 1951, with the British agreement in principle to grant independence to the colony, this stage of decolonization gave way to a period of domestic struggles for power on the eve of independence. At this junction, the internal tensions that had been somewhat in check erupted into an open clash over the control of the colonial state." This left Nkrumah (who was from a minor Akan ethnic group — the Nzima) with a very precarious political base. To compensate for this Nkrumah engaged in a "divide and rule" strategy with respect to the Ashanti (whose chiefs were one of his strongest opponents) by attempting to set different factions of commoners against the chiefs. The chiefs and their National Liberation Movement (NLM) "met the nationalist appeal of the CPP with a rival nationalism

of its own, through an impassioned demand for recognition of the traditional unity of the Ashanti nation," Austin (1964, p. 250). This political strategy ensured Nkrumah's 
power at independence in 1957. After the departure of the British, he moved to suppress the opposition and altered the Constitution (in a fraudulent plebiscite) to strengthen his powers. Pellow and Chazan (1986, p. 41) argue that

"The 1960 constitutional referendum ... augmented the powers of the executive ... Nkrumah was elected president of the First Republic, and thus, for all intents and purposes, by 1960 Ghana had become a one-party state with Nkrumah as its leader. The authoritarian tendencies apparent during decolonization were officially entrenched in the centralized and personalized pattern of government that emerged at this juncture."

Despite the announced objectives of modernization, the need to stabilize political power seems to have been the key determinant of economic policies. Pellow and Chazan (1986, p. 45) argue that by 1964 the CPP had "reduced the role of the state to that of a dispenser of patronage. By advocating the construction of a ramified bureaucracy, Nkrumah established a new social stratum directly dependent on the state. By curtailing the freedom of movement of these state functionaries through the diversion of administrative tasks to political ends, the regime contributed directly to undermining their effective performance."

The disastrous economic impact of the CPP's policies have been well analyzed by Bates (1981) (see also Owusu, 1970, and Leith and Loftchie, 1993). He showed that the government used the state Cocoa marketing board and exchange rate policy to systematically expropriate the coca farmers who dominated the economy and exports. The CPP transferred these rents to the urban and ethnic interests which supported them. The fact that this redistribution took such an inefficient form was explained both by the inability of the central state to control or raise taxes in the countryside, and by the political rationality of redistributing in ways which could be selectively targeted. Bates (1981, p. 114) argues:

"Were the governments of Africa to confer a price rise on all rural producers, 
the political benefits would be low; for both supporters and dissidents would secure the benefits of such a measure, with the result that it would generate no incentives to support the government in power. The conferral of benefits in the form of public works projects, such as state farms, on the other hand, has the political advantage of allowing the benefits to be selectively apportioned. The schemes can be given to supporters and withheld from opponents."

Bates applied a similar argument to explain the overvaluation of the exchange rate. When the foreign exchange market does not clear, the government has to ration access to foreign exchange and can target allocations to supporters. In addition, and perhaps more important, overvalued exchange rates directly transfer resources from the rural sector to the urban sector, making it an attractive policy tool for the political elites.

These distortionary policies did not stop when Nkrumah was deposed in 1966; they were in fact intensified right up until Rawlings's policy changes of 1982 (see Herbst, 1993, on these changes and the more recent economic and political history).

Ghana therefore provides a clear example of how a range of distortionary policies, including overvalued exchange rates, were motivated by the desire to redistribute income. The bad effects were so severe and debilitating for the economy because the institutional environment inherited from Britain placed few, if any, constraints on what politicians could do. Nkrumah and the CPP were able to build a one-party state, use the bureaucracy and economic policies for patronage and engage in mass corruption. The high political stakes that resulted made it very attractive to be in power and induced intense political instability, as shown by the very frequent coups, and political instability translated into economic instability. Overall, it seems fairly clear that in the Ghanaian case, economic instability was caused mainly by institutional weaknesses, which was mediated by a range of different macro and micro policies. 


\subsubsection{Argentina}

In any discussion of crises and poor growth in developing countries Argentina tends to come near the top of anyone's list. Argentina is the most famous case of a country which ought to be relatively prosperous, and indeed was so until the 1920s. It is standard to blame poor economic performance and volatility in Argentina on bad economic policies. The usual candidate for low growth is inward-looking industrialization and irresponsible fiscal policy (Krueger, 1993, Taylor, 1998).

The traditional story for why Argentina pursued such policies is the adoption of misguided state-led development strategies as a result of the influence of economists such as Prebisch and the dependency theorists (Krueger, 1993). Yet Peronist policies predated Prebisch's seminal work in $1950,{ }^{7}$ and the reality is that Perón never followed a coherent industrialization policy. Gerchunoff (1989) sums up Peronist economic policy in the following way:

"there was no specific and unified Peronist economic policy, much less a long-term development strategy. In spite of official rhetoric about a plan, the objective - and at times exclusive - priority was ... an economic order capable of maintaining the new distributive model."

The first real statement of Prebisch's views was in his famous work of 1950, and he had no influence on policy in Argentina until 1955, when he was recalled from exile following Perón's fall from power.

A second view sees the great depression and the Second World War as leading to a phase of "natural import substitution," which then created an industrial interest group. This interest group was sufficiently strong that it could induce state subsidies and intervention (this view is developed in Frieden, 2002). Both this theory and the one emphasizing mistaken economic theories see bad industrial policies and state intervention leading also to unsustainable subsidization, fiscal insolvency, bankruptcy and hyperinflation.

\footnotetext{
${ }^{7}$ Perón came to power in 1943 and indeed Prebisch was hounded from Argentina and into exile in Chile by Perón.
} 
A third view, popular in political science, sees the cause of the form of both macroeconomic and microeconomic policy in the rise and persistence of "populism" and more specifically Peronism (Waisman, 1987, Collier and Collier, 1991, Roe, 1998). This view tends to see structural changes in the economy, such as urbanization and the rise of organized labor, as leading to particular sorts of political coalitions, favoring certain policies, and preventing economic development.

Although there are undoubtedly aspects of truth in these explanations, a more satisfactory account of poor economic policies in Argentina situates them in their institutional context. It seems that Perón's policies, and subsequent Argentinian policies, were not really a reflection of a "full-blown Peronist growth strategy" as argued by Shleifer (1997), or aimed at "the goal of rapid industrialization" and "the intent of building a domestic industrial base behind tariff rates," as argued by Sachs (1990, p. 148). Instead, these were policies intended to transfer resources from one segment of society to another, as well as a method of maintaining power by politicians with a weak social base in an institutionally-weak society (see, Gerchunoff, 1989, and Mazzuca, 2001). In line with this view, Diaz Alejandro (1970, p. 126) concludes that

"Peronist policies present a picture of a government interested not so much in industrialization as in a nationalistic and populist policy of increasing the real consumption, employment, and economic security of the masses - and of the new entrepreneurs. It chose these goals even at the expense of capital formation and of the economy's capacity to transform."

Where do the institutional weaknesses of the Argentine society come from? ${ }^{8}$ As a Spanish colony Argentina had low population density and was something of a backwater because of the focus on the mines of Peru and Bolivia. It thus avoided many of the worse colonial institutions, such as the encomienda and the mita. Nevertheless, after independence Argentina suffered from severe political instability as rival regional warlords

\footnotetext{
${ }^{8}$ Our account here builds on Mazzuca (2001).
} 
and Caudillos vied for control of Buenos Aires and the country. An effective national state emerged only in the 1860s under the Presidency of Mitre. In order to secure compliance, the constitutional settlement and institutions created then ceded large powers to the provinces. Crucially, the central state never imposed upon the regions the type of centralized institutions constructed historically in Europe. Mazzuca (2001) suggests, building on the work of Tilly (1990) and Herbst (2000), that this was because: (1) the Argentine regime did not face external threats to its sovereignty and was therefore never forced to modernize; (2) both the expanding world commodity and financial markets gave the central governments enough fiscal resources that they could use to avoid the costs of disciplining the provinces. ${ }^{9}$ Although this institutionalization of political power did not impede the boom in Argentina up until 1920s, it left a legacy of political institutions which has had a crucial impact on policy over the last century. Our argument is that in particular it has led to highly inefficient forms of redistribution away from the most productive parts of the country (Buenos Aires and the littoral) towards the economically marginal, but politically salient provinces. Politicians undertook this type of inefficient redistribution using a variety of tools, ranging from fiscal policy and exchange rate policy to microeconomic policies.

A tangible manifestation of this perverse institutionalization of political power can been seen from the malapportionment of the Argentine congress. Samuels and Snyder (2001, 2002) show that Argentina has the most malapportioned Senate in the world and that the degree of malapportionment of Congress is about 2.5 times the world average and $50 \%$ higher than the Latin America average. ${ }^{10}$ The four provinces of Buenos Aires, Santa Fe, Córdoba and Mendoza contain $78 \%$ of national industrial production and $70 \%$ of the total population, but control just 8 of the 48 seats in the senate, and $48 \%$ of the

\footnotetext{
${ }^{9}$ Rock (1987, p.125 ) notes "Mitre became adept in the dispensation of subsidies to the provinces."

${ }^{10}$ Measuring malapportionment by the proportion of seats that are not allocated on the basis of oneperson one vote, the Argentine Senate has a score of 0.49 and the Congress 0.14. The world and Latin American averages are, respectively, 0.27 and 0.19 for Upper Chambers and 0.09 and 0.06 for lower chambers. Note that while the U.S. Senate is malapportioned (score 0.36), the U.S. Congress is not malapportioned. Gibson, Calvo and Faletti (2001) provide evidence suggesting that it is malapportionment in the lower chamber that is the main determinant of fiscal redistribution.
} 
seats in Congress. Gibson (1997) refers to these four provinces as the 'core' and the other provinces as the 'periphery' and shows that political support from the periphery has been crucial in Argentine politics (see also Germani, 1962, Mora y Araujo and Llorente, 1980). In particular, the Peronists, despite the conventional wisdom that they are the party of labor and urban interests, have always relied heavily on this support.

Gibson, Calvo and Faletti (2001, p. 11) argue that the importance of "overrepresented peripheral region provinces in the national Peronist coalition has continued to the present day, and during President Menem's first term they provided a major base of support in the national legislature." The nature of this political coalition led Menem to insulate the periphery from most of his economic reforms. During his presidency, public sector employment and subsidies to the periphery increased despite rapid retrenchment and deregulation in Buenos Aires (Gibson, Calvo and Faletti, 2001, Table 6). This structure of political institutions is important because it leads the peripheral regions to be a crucial part of any political coalition and leads, as in Ghana, to the burden of redistribution falling squarely on the most productive region of the country.

Nevertheless, political institutions such as these, while they may have large effects on policy, are not determined randomly. Indeed, malapportionment was intensified by Perón in 1949 when he established a minimum of two deputies per province regardless of population (Sawers, 1996, p. 194). It was further increased by the military in 1972 and the early 1980s in an attempt to weaken the power of urban interests in democracy. This process was driven by the initial political equilibrium favoring the periphery and thus further intensified the inherent institutional distortions. ${ }^{11}$

\footnotetext{
${ }^{11}$ There are many ways in which malapportionment can affect the efficiency of economic policy. For example, imagine that to put together a coalition, a President must give politicians enough redistribution for them to be re-elected. In this case, it is cheaper to "buy" a politician from a peripheral province in Argentina since he needs fewer votes to win. This "price" can influence the form that payment takes (see the model by Lizerri and Persico, 2001, for a formalization of a related idea). For example, when the price is low it may be rational to buy politicians with private goods (income transfers), while when it is high (for instance in Buenos Aires) it is cheaper to use public goods. Malapportionment can then lead to the undersupply of public goods. Moreover, anticipating the cost of 'buying' power, a President may want to create malapportionment because he has to redistribute less in total and keeps more of the rents from power.
} 
This perspective suggests that the repetitive nature of unsustainable and bad macroeconomic policies in Argentina stems from an underlying set of weak institutions, which make massive redistribution of income feasible and even politically rational. This analysis is rather different from much current analysis.

The recent crisis in Argentina has been explained by the collapse of an unsustainable economic model which involved tying the peso to the US dollar. This resulted in overvaluation, domestic recession and a current account deficit that had to be funded by unsustainable international borrowing. The conventional wisdom is that the adoption of this particular set of policies was an attempt to obtain credibility with financial markets (e.g. Rodrik, 2002). Instead, our perspective suggests that, as in Bates's (1981) analysis of the political economy of Africa, bad economic policies should be understood as part of a package of often inefficient redistributive tools. The currency board adopted by Argentina also created clear winners and losers. The economically poor but politically pivotal periphery gained transfers and was unthreatened by the adverse effects of a crisis that had greater effects on the core and the middle classes (who are now being "expropriated" by a variety of methods). ${ }^{12}$ The persistent nature of crises and expropriation in Argentina, and the fact that the same set of macroeconomic policies continually recur and subsequently collapse (see della Paolera and Taylor, 2001) are consistent with our interpretation. ${ }^{13}$

Some recent analyses (e.g. Caballero and Dornbusch, 2002) recognize the existence of "political and social problems," but still maintain the view that bad policy in Argentina is either misguided or incompetent, and argue that the policy failures in Argentina can now only be solved by an international takeover of fiscal and monetary policies. Our analysis here suggests that this solution to instability and poor economic performance in Argentina may not be successful. If at root the problems are weak institutions leading to

\footnotetext{
${ }^{12}$ Undoubtedly the form of the monetary policy helped to bring down inflation, but this does not imply that the main objective of the set of policies adopted was to promote development and stability.

${ }^{13}$ A significant example of absence of constraints on the executive in Argentina is the ability of Menem to re-write the Constitution in 1995 so that he could run for the presidency again.
} 
political conflict, highly inefficient redistribution and outright predation, then, without institutional change, distributional conflict is bound to resurface even if international bankers are in control of monetary policy. There are always other instruments.

\section{Empirical Strategy}

The discussion so far illustrates how we might expect both institutional differences and differences in macroeconomic policies to cause differences in macroeconomic performance, especially in volatility and crises. We now discuss a simple empirical strategy to make progress in distinguishing between these two sources of differences in volatility and crises.

Ignoring nonlinearities, the economic relationship we are interested in identifying is:

$$
X_{c, t-1, t}=Q_{c, t-1, t}^{\prime} \cdot \alpha+\beta \cdot I_{c, t=0}+Z_{c, t-1, t}^{\prime} \cdot \gamma+\theta \cdot \ln y_{c, t-1}+\varepsilon_{c, t-1, t}
$$

where $X_{c, t-1, t}$ is the macroeconomic outcome of interest for country $c$ between times $t$ and $t-1$. The three outcomes that we will look at are overall volatility (standard deviation of GDP per capita growth), severity of crises (worst output drop) and average per capita growth. In our baseline regressions, the basic time period will be from 1970 to 1997 (this choice is dictated by data availability and our desire to start the analysis at a point in time where the countries for which we have data are all independent nation states). $Q_{c, t-1, t}^{\prime}$ is a vector of macroeconomic policies for country $c$ between times $t$ and $t-1$. The three measures of macroeconomic policies we will look at are the ones shown in Section 2: average size of government consumption, inflation, and real exchange rate overvaluation.

$I_{c, t=0}$ is our measure of institutions at the beginning of the sample. We will use the constraint on the executive variable from the Polity IV dataset, which measures the extent of constitutional limits on the exercise of arbitrary power by the executive. The Polity dataset reports a qualitative score, between 1 and 7, for every independent country. In previous work (e.g., Acemoglu, Johnson and Robinson, 2001 and 2002a), 
we showed that this measure is correlated with other measures of institutional quality and with economic development. As our baseline measure, we use the average value for this constraint from the Polity IV dataset for 1950, 1960 and 1970, assigning the lowest score to countries that are not yet independent (and therefore not in the Polity IV dataset). ${ }^{14}$ This is reasonable since in a country still under colonial control there are typically few real constraints on the power of the rulers. Appendix Tables A3, A4 and A5 provide results using constraint on the executive in 1970 as an alternative measure of institutions, with qualitatively and quantitatively very similar results.

In addition, in equation (1), $Z_{c, t-1, t}$ is a set of other controls, and $\ln y_{c, t-1}$ is the log of initial income per capita, which we include in some of the regressions. Following Barro (1991) this variable is included in most growth regressions to control for convergence effects. It is also useful to include it in regressions of volatility or crises, since as shown in Acemoglu and Zilibotti (1997), poorer countries suffer substantially more volatility.

The parameters that we are interested in identifying are $\alpha$ and $\beta$, the effect of macroeconomic policy variables and institutions. ${ }^{15}$ The simplest strategy is to estimate the model in equation (1) using ordinary least squares (OLS) regression. There are two distinct problems with this strategy:

1. Both institutions and macro policy variables are endogenous, so we may be capturing reverse causality, or the effect of some omitted characteristics (geography, culture, or other variables) on both policy (or institutions) and economic outcomes.

2. Both institutions and policy variables are measured with error, or in the case

\footnotetext{
${ }^{14}$ We take these averages of 1950, 1960 and 1970 as our baseline measure, rather than simply use the 1970 value of the index, since we are interested in the long-run component of these constraints (not in the year-to-year fluctuations) and also because the Polity dataset gives high scores to a number of former colonies in 1970 that subsequently drop by a large amount. This reflects the fact that many of these countries adopted the constitution of their former colonial powers, but did not really implement the constitution or introduce effective checks.

${ }^{15} \mathrm{In}$ addition it is interesting to look at whether there is an interaction between institutions and macro policy variables. We can add the interaction term $Q_{c, t-1, t}^{\prime} \cdot I_{c, t-1}$, and investigate whether there is a non-monotonic relationship between institutions and volatility, i.e., add higher order terms $I_{c, t-1}$ to the regression equation (1). In our empirical work, such interaction and higher order terms are never significant, so we do not report them in the paper.
} 
of institutions, available measures correspond only poorly to the desired concept (more explicitly, while the institutions we have in mind are multi-dimensional, "constraint on the executive" only measure one of these dimensions, and that quite imperfectly).

Both of these concerns imply that OLS regressions will give results that do not correspond to the causal effect of institutions and policy variables on economic outcomes. So we would like to estimate equation (1) using Two-Stage Least Squares (2SLS) with distinct and plausible instruments for both macro policy variables and institutions. These instruments should be correlated with the endogenous regressors, and they should be orthogonal to any other omitted characteristics and not correlated with the outcomes of interest through any other channel than their effect via the endogenous regressors.

In this paper, we pursue the strategy of instrumenting for institutions using the historically-determined component of institutions, arising from the colonial experience of former colonies. The instrument will be discussed in detail in the next section. To the extent that the instrument is valid, it will solve the endogeneity, the omitted variables bias and the measurement error problems. In particular, if the instrument is valid, we can estimate the effect of institutions on economic outcomes, the $\beta$ parameters, consistently in models that exclude the macro policy variables.

When the macro policy variables are also included, the simplest strategy is to treat them as exogenous. Ignoring the measurement error problem, the coefficients on these policy variables, the $\alpha$ parameters, will be typically biased upwards. The Appendix of Acemoglu, Johnson and Robinson (2001) shows that in this case there may also be a downward bias in $\beta$, the effect of institutions on outcomes. Therefore, our simplest strategy of instrumenting for institutions and treating macro policy variables as exogenous is "conservative", in the sense that it stacks the cards against finding a substantial role for institutions and in favor of finding an important role for macro policy variables (unless measurement error in these policy variables is a major problem). Moreover, equation (1) shows that we are using contemporary averages of the macro variables, while using 
lagged values of institutions. This is again in the spirit of stacking the cards in favor of finding a significant role for macro variables. As it turns out almost all of our regressions will show a major role for institutions, and more limited and less robust influence from the macro variables. So our conservative strategy makes the interpretation of these results simpler.

A caveat for the above discussion is that if the measurement error in macro variables is significant, their coefficients might be biased downward due to attenuation bias. Since we are taking thirty-year averages of these variables, the measurement error problem should not be too severe. ${ }^{16}$ As an alternative strategy for dealing both with attenuation bias and endogeneity of the macro variables, we also report regressions where we instrument for the macro variables with their lagged values when available. We will see that these specifications give similar results to those where these policy variables are treated as exogenous.

Another possible concern is that distortionary policy may matter for macroeconomic variables, but we may be unable to detect this because we are taking averages over thirty-year periods. This would be the case if, for example, some of the countries go through a period of about 5 to 10 years of high inflation or an overvalued exchange rate, causing major crises, but during other periods they have offsetting low inflation and undervalued exchange rates, making their average policies similar to those in other countries. To deal with this problem, we estimate a variation on our basic regression using a panel of 5-year averages for each country between 1970 and 1997 (or shorter periods for some of the macro variables), with the following structure:

$$
X_{c, t-1, t}=Q_{c, t-1, t}^{\prime} \cdot \alpha+\beta \cdot I_{c, t=0}+Z_{c, t-1, t}^{\prime} \cdot \gamma+\theta \cdot \ln y_{c, t-1}+\delta_{t-1, t}+\varepsilon_{c, t-1, t},
$$

where all the variables are defined similarly to equation (1), except that we now have a full set of time effects for every five-year episode, the $\delta_{t-1, t}$ terms. In addition, we still

\footnotetext{
${ }^{16}$ Unless there is again attenuation bias caused by the variables in question not corresponding to the conceptually appropriate policy variables. We believe this possibility is unlikely in the case of the policy variables, since these are the variables emphasized in the policy discussions and the relevant literature, and we have experimented with many other variables.
} 
use the institutions at the beginning of the sample, $I_{c, t=0}$. Recall that our interest is in the historically-determined component of institutions (that is more clearly exogenous), hence not in the variations in institutions from year-to-year. As a result, this regression does not (cannot) control for a full set of country dummies. Since we have more than one observation per country, but one of our key regressors only varies by country, we cluster the standard errors by country (using the Stata robust standard errors). If some countries have volatile macroeconomic policies that matter only when they reach very extreme values, this specification should show a greater role for policy variables than the cross-sectional regression (1). In practice, estimates of the impact of policy variables on volatility, crises and growth from equations (1) and (2) are quite similar.

\section{Sources of VARiation in Institutions}

The empirical strategy outlined in Section 4 relies on a valid instrument for institutions. Our idea is to exploit the historically-determined component of institutions, or in other words, instrument for institutions with historical variables. This clearly solves the simple "reverse causality" problem, and to the extent that the instrument is plausibly orthogonal to other omitted determinants of economic outcomes, such as volatility, crises and growth, it also avoids the omitted variable bias. Also, the instrumentation strategy removes the attenuation bias (as long as the "measurement error" or the conceptual discrepancy between our measure and the true concept can be approximated by classical measurement error).

\subsection{Historical Determinants of Institutions Among Former European COLONIES}

The set of former European colonies provides an attractive sample for isolating the historically-determined component of institutions, since the institutions in almost all of the former colonies have been heavily influenced by their colonial experience (see Acemoglu, Johnson and Robinson, 2001, for a more detailed discussion on this point). 
In Acemoglu, Johnson and Robinson (2001, 2002a), we contrasted institutions of private property, which protect the property rights of a broad segment of society, and extractive institutions, which lack constraints on elites and politicians. We argued that institutions of private property, which correspond to effective constraints on elites and rulers, were more likely to arise when Europeans settled in large numbers, and set up institutions protecting their own rights. The "Neo-Europes," the U.S., Canada, Australia and New Zealand, are perhaps the best examples of the high European settlement associated with the development of good institutions. In contrast, extractive institutions emerged when Europeans pursued a strategy of extracting resources from the colonies without settling and without developing participatory institutions. While there are many determinants of the exact colonization strategy pursued by European powers, an important determinant is naturally whether Europeans could settle or not, since where they could not settle, the extractive strategy was much more likely. ${ }^{17}$ Therefore, in places where the disease environment was not favorable to European health and settlement, we expect the formation of extractive states, and today the presence of weak institutions, as these extractive institutions persist. This reasoning suggests that proxies for mortality rates expected by the first European settlers in the colonies could be an instrument for current institutions in these countries. Schematically, the reasoning underlying this instrumentation strategy is:

$$
\begin{gathered}
\text { (potential) settler } \\
\text { mortality }
\end{gathered} \Rightarrow \text { settlements } \Rightarrow \begin{gathered}
\text { early } \\
\text { institutions }
\end{gathered} \Rightarrow \underset{\text { current }}{\text { institutions }} \Rightarrow \underset{\text { current }}{\text { performance }}
$$

Based on this reasoning, we use data on the mortality rates of soldiers, bishops, and sailors stationed in the colonies between the 17th and 19th centuries (Curtin, 1989, and 1998, and Gutierrez, 1986). These give a good indication of the mortality rates faced by settlers. Europeans were well informed about these mortality rates at the time, even though they did not know how to control the diseases that caused these high mortality

\footnotetext{
${ }^{17}$ Another important determinant appears to be population density. Europeans were less likely to settle in already densely-settled areas, and more likely to pursue extractive strategies given the level of settlement (Acemoglu, Johnson and Robinson, 2002a). We obtain similar results to those reported below if we use population density in 1500 as an additional instrument.
} 
rates, especially yellow fever and malaria (see the discussion in Acemoglu, Johnson and Robinson, 2001).

A major concern is the validity of the exclusion restriction presumed by this instrumentation strategy - i.e., whether the mortality rates faced by the settlers between the 17th and 19th centuries could actually have an effect on current outcomes through another channel. Probably the most important threat to the validity of our instrument comes from the correlation between European mortality rates over 100 years ago and the health of the current population or climate, and the effect of current health and climate on current economic outcomes. We believe that this concern does not invalidate our approach and that our exclusion restriction is plausible. The majority of European deaths in the colonies were caused by malaria and yellow fever. Although these diseases were fatal to Europeans who had no immunity, they had much more limited effects on indigenous adults who, over the centuries, had developed various types of immunities. These diseases are therefore unlikely to be the reason why many countries in Africa and Asia are very poor today. This notion is supported by the mortality rates of local people in high-settler mortality areas, which were comparable to the mortality rates of British troops serving in Britain or in healthier colonies (see for example Curtin, 1998, Table 2). To substantiate the validity of our instrumentation approach, in Acemoglu, Johnson and Robinson (2001) we showed that the results are robust to controlling for climate, humidity, other geographic variables, and current health conditions, and that we obtain very similar results exploiting only differences in European mortality due to yellow fever, which is an attractive source of variation, since yellow fever has been mostly eradicated. On the basis of these findings, we take mortality rates of European settlers between the 17th and 19th centuries as an instrument for current institutions in the former colonies. ${ }^{18}$

Figure 5 shows the first-stage relationship between our constraint on the executive variable (an average for 1950, 1960 and 1970) and the log of European settler mortality in annualized deaths per thousand mean strength. This measure reports the death

\footnotetext{
${ }^{18} \mathrm{We}$ also show in Acemoglu, Johnson and Robinson (2001) that these mortality rates were a firstorder determinant of early institutions, and these institutional differences have persisted to the present.
} 
rate among 1,000 soldiers where each death is replaced with a new soldier and was the standard measure in army records, where much of the information comes from. We use logs rather than levels, since otherwise some of the African observations are extreme outliers. The figure shows a strong relationship between the measure of institutions used in this paper and settler mortality more than 100 years ago. Our interpretation is that this reflects the causal effect of colonial policies on current institutions, and hence it can serve as a useful source of variation for identifying the effect of institutions on macroeconomic outcomes.

\subsection{Institutions And Economic Outcomes: A First Look}

We now briefly look at the relationship between the historically-determined component of institutions and current economic outcomes. The first column in Table 1 replicates our main regression from Acemoglu, Johnson and Robinson (2001), which looks at the effect of institutional differences on (log) income per capita today. The lower part of the panel shows the first-stage relationship. In Acemoglu, Johnson and Robinson (2001), we used average protection against expropriation risk between 1985 and 1995 as our measure of institutions. Here, we prefer a measure that refers to the beginning of our sample (i.e., 1970), and protection against expropriation is not available for the 1960s and 1970s. Column 4 replicates the same regression using the constraint on the executive variable used in this paper. The first-stage relationship for this regression is shown in Figure 5 .

Columns 7 and 10 turn to a regression of the average growth rate between 1970 and 1997 on an average of constraint on the executive in 1950, 1960 and 1970, again instrumented by log settler mortality (with or without controlling for initial income). Throughout the paper, we express all growth rates in percentage points (e.g., 2 percent rather than 0.02) to save on decimal points; see Appendix Table A2 for summary statistics. Column 7 shows a statistically significant relationship, indicating faster growth in the postwar era among countries with better historically-determined institutions. For 
example, the coefficient of 0.75 implies that a country like the U.S., with a value of constraint on the executive of 7 , is predicted to grow about 3 percent a year faster than a country like Nigeria, with a score of 3 . The coefficient estimate of the effect of initial "constraint on the executive" on growth becomes larger when we control for initial income in column 10, but also the standard error more than triples (though the coefficient is still statistically significant at the 5 percent level). This is a pattern we see throughout the paper; regressions with economic growth as the dependent variable are less robust than regressions for volatility or largest output drop, especially when we control for initial income. At some level, it is not surprising that the relationship between the historically-determined component of institutions and postwar growth becomes substantially weaker when we control for initial income: initial income is determined largely by institutions, so our measure of institutions and initial income are highly correlated. In fact, much of the divergence among former colonies took place between 1750 and 1950, when countries with good institutions took advantage of industrialization and modernization opportunities, and those with extractive institutions failed to do so (see Acemoglu, Johnson and Robinson, 2002a). So our measure of institutions may be a much better determinant of the level of income in 1970 than subsequent growth.

It is useful to know whether the relationship between the historically-determined component of institutions and economic outcomes is driven mainly by the contrast between rich and poor nations. Columns 2, 5, 8 and 11 report similar regressions for countries above the median world per capita income in 1970 (using the Summers-Heston income per capita data for that year, from the Barro and Lee dataset). In these regressions, and all those in subseqent tables that use this subsample, we drop Gabon, which is an outlier with high volatility (including Gabon in this subsample does not change the results). In Table 1, the estimates for this subsample are similar to, but slightly lower than, those for the sample of all excolonies. They continue to be highly significant in income level regressions (columns 2 and 5), but are only significant at the 10 percent level in the growth regressions (columns 8 and 11). 
Finally, columns 3, 6, 9 and 12 report regressions for excolonies without Africa, to show that the effect of the historically-determined component of institutions on income level and growth is not driven by a contrast between African and non-African nations. In this smaller sample, the 2SLS estimate of the effect of institutions on economics outcome is again slightly lower than that for all excolonies. Nevertheless, this estimate is still significant at the 5 percent level in the income level regressions, and significiant at the 10 percent in the growth regressions. In the subsequent analysis, we find that the results without Africa are similar to those that just use countries above median world per capita income, so we just report the latter.

\section{Institutions, Macroeconomic Policies, Macroeconomic Outcomes}

In this section we look at the effect of institutions and macroeconomic policies on volatility, and also on the severity of crises and growth. We start with the relationship between institutions and macro variables, and then investigate their relative influences on volatility more carefully. In the next section, we investigate the robustness of the relationship between institutions and volatility in more detail, and look for potential mechanisms.

\subsection{The Effect of Institutions on Policies and Volatility}

Table 2 shows the relationship between institutions, on the one hand, and the three macroeconomic variables discussed above and our measures of volatility and crises, on the other. More specifically, we run regressions of the form

$$
\begin{aligned}
& Q_{c, t-1, t}=\beta^{q} \cdot I_{c, t=0}+\varepsilon_{c, t-1, t}^{q}, \text { and } \\
& X_{c, t-1, t}=\beta^{x} \cdot I_{c, t=0}+\varepsilon_{c, t-1, t}^{x},
\end{aligned}
$$

where $Q$ denotes the macro policy variables, $X$ denotes our measures of volatility and crises, and $I_{c, t=0}$ is the measure of constraint on the executive at the beginning of the sample (average constraint on the executive in 1950, 1960 and 1970).

In Panel A, we first report OLS estimates of equation (3). These regressions show 
that weaker institutions are associated with larger government sectors, higher inflation rates, more overvalued exchange rates, greater volatility, and more severe crises (though the associations between institutions and macroeconomic policy variables are not statistically significant in the sample of former colonies above median world income).

Our interest is not in statistical associations, but in uncovering the causal effect of institutions on macroeconomic distortions and volatility. For this reason, Panel B reports 2SLS estimates of equation (3). In these estimates, the institutions variable is instrumented with log settler mortality. The first-stage relationships for institutions are identical to those shown in Table 1 (since there are no other covariates here).

The results are similar to the OLS estimates, but somewhat stronger. For example, the coefficient on $I_{c, t=0}$ in the government consumption regression changes from -0.012 to -0.018 . This indicates that the attenuation bias caused by our use of imperfect measures of institutions is probably more serious than the endogeneity bias (see Acemoglu, Johnson and Robinson, 2001, for a discussion on this issue). To the extent that our instrument is valid, this corresponds to the causal effect of institutions on macroeconomic policies. We can therefore conclude that some societies pursue distortionary macroeconomic policies, in particular, in the form of high inflation, larger government sectors, overvalued exchange rates and other distortionary macroeconomic prices because they have (or have had) weak institutions. This raises the question of whether the correlation between the distortionary policies and macroeconomic volatility (and other bad macroeconomic outcomes) shown in Figures 2, 3 and 4 reflects the effect of macroeconomic policies or the direct effect of institutional problems working through other potentially non-macroeconomic channels.

The bottom panel of Table 2 also shows the relationship between institutions and volatility (columns 7 through 10) and severity of crises (columns 11 through 14). Countries with institutional problems suffer substantially more volatility. For example, the estimate of -0.83 in column 9 (bottom panel) implies that a 1 point higher score in the institutional index translates into about a 0.83 decline in the standard deviation 
of growth. So on the basis of this estimate, we should expect a country like the U.S., which has an institutional score of 7 , to have a standard deviation 3.32 lower than a country like Nigeria which has an institutional score of 3. This gap is approximately two-thirds of the actual gap in standard deviation between the U.S. (2.16) and Nigeria (7.37) in the data, which is 5.21. When we also control for initial income, the coefficient is -1.56 , and correspondingly, the predicted volatility difference between the U.S. and Nigeria is now 6.24, which is a little larger than the actual gap. Notice however that in this specification including initial income, the standard error on the institutions variable is substantially larger (0.58 instead of 0.20$)$. This is not surprising since, as noted above, the historically-determined component of institutions is a very good predictor for income in 1970, making our institutions variable and log in GDP per capita 1970 highly colinear. Nevertheless, our institutions variable is significant at the 1 percent level, while the initial income variable is not significant at the 5 percent level. This is a pattern we will see repeatedly below, and suggests that institutions have a first-order effect above and beyond the influence of initial income on volatility emphasized in Acemoglu and Zilibotti (1997). ${ }^{19}$

Recall that to the extent that our instrument for institutional differences is valid, what we are estimating in this bottom panel of Table 2 is the causal effect of institutional differences on volatility. So the key questions are whether this causal effect is being mediated by macroeconomic variables such as inflation, fiscal policy and exchange rate policy, and whether differences in these macroeconomic policies unrelated to institutions have a first-order effect on volatility and macroeconomic outcomes. We turn to these issues next.

\footnotetext{
${ }^{19}$ It also suggests that the relationship between initial income and volatility, which Acemoglu and Zilibotti (1997) interpreted as due to lack of sectoral diversification in relatively poor countries, may be related to institutional factors.
} 


\subsection{Institutions Versus Macroeconomic Policies: Interpretation}

How can we interpret the results from regressions as in equations (1) and (2), which include both institutions and macroeconomic variables? Imagine that we are estimating these regressions with volatility as the dependent variable. We know from Table 2 that institutions have an effect on volatility, which we can interpret as causal as long as we trust the validity of our instruments. So now imagine adding the macro variables, $Q$, to regressions of measures of volatility and crises on institutions. Consider the following alternative scenarios:

1. If we find institutions are insignificant, while macroeconomic policies are significant, the most likely interpretation, in light of the results of Table 2 that show that a large "causal" effect of institutions on volatility, is that institutions have an effect on volatility, but these specific macroeconomic policies are the main (primary) mediating channel for this effect. (This naturally does not rule out that macroeconomic policies may have an independent effect, unrelated to the importance of institutions.) Since macroeconomic policies are the main mediating channel, these results would suggest that getting macroeconomic policies right, as prescribed by the Washington consensus, is likely to be an important policy priority.

2. If, on the other hand, both institutions, $I$, and macroeconomic policies, $Q$, are found to be robustly significant, it would appear that both have independent effects on volatility, and part of the effect of institutions may be mediated through macroeconomic policies, while some part of it is not. We can determine approximately how much of the effect of institutions is mediated by macroeconomic policy variables by looking at the change in the coefficient on institutions between the specifications with and without the macro variables. If this coefficient changes only little, it would appear that these specific macroeconomic policies are not the main mediating channel for the effect of institutions on volatility (or other economic outcomes). 
3. Finally, if we find that institutions, $I$, are significant and macroeconomic policies, $Q$, are not, the most likely interpretation is that the causal effect of institutions on volatility is not mediated mainly through macroeconomic policies, but through a range of other, probably microeconomic, policies. Macroeconomic policies in this case might still have an effect in individual cases; but they are not the systematic channel via which institutions impact on volatility. In this case, the effect of institutions on volatility is likely to be working not through a particular mechanisms, but via a variety of microeconomic, as well as macroeconomic, channels (thus potentially leading to the "seesaw effects" mentioned in the introduction).

\subsection{Institutions Versus Macroeconomic Policies: Volatility}

We now estimate models as in equations (1) and (2), with volatility as the dependent variable. The results presented in Tables 3,4 , and 5 show a robust effect of institutions, and no effects from government consumption or inflation. ${ }^{20}$ Overvaluation is, on the other hand, significant in some specifications, but has a relatively small effect on the coefficient of the institutions variable. These results therefore favor an interpretation in which standard macroeconomic variables play a minor role relative to institutional causes that create economic instability through a variety of channels, though overvaluation of the exchange rate appears one of the channels linking weak institutions to greater instability, even if not the primary channel.

In Table 3, we report regressions with volatility as the dependent variable, and average ratio of government consumption to GDP (a measure of average government size) as the macro variable. We chose this variable as it appears to be a better predictor of macroeconomic outcomes during this period than measures of the budget deficit. The first three columns in the top panel document a strong relationship between the size of government and volatility, without controlling for institutions, as already shown

\footnotetext{
${ }^{20}$ These baseline results use the average constraint on the executive in 1950, 1960 and 1970. See Appendix Table A3 for results using constraint on the executive in 1970.
} 
in Figure 2. The second panel shows that a similar but weaker relationship applies when we control for initial income. Greater government size is associated with greater instability. The rest of the table shows that adding institutions reduces the importance of the government size variable, which is never found to be significant. ${ }^{21}$

In columns 4 and 5, we start with OLS regressions, where institutions are treated as exogenous. These regressions show a negative relationship between constraint on the executive and volatility, both in the full excolonies sample and in the smaller sample of excolonies above median world income. The correlation between government consumption and volatility is no longer significant. The results are similar when we control for initial income in Panel B: institutions continue to be significant and government size is not.

In columns 6 and 7, we instrument for institutions using (potential) European settler mortality, as in previous tables, and treat government size as exogenous. The effect of institutions on volatility is now stronger, and there is also no effect of government consumption (the coefficient is now almost zero down from 8.09).

Average size of government over the sample period may be correlated with other determinants of volatility, and may also be measured with error. To deal with these endogeneity and attenuation issues, columns 8 and 9 instrument for government size using past government size. Now the government size variable has the opposite sign to those in columns 1, 2 and 3 and is far from being significant. This is despite the fact that there is a good first-stage relationship for government size (the t-statistic on past government consumption is over 10 , and the $\mathrm{R}^{2}$ of the first-stage regression is 0.69 ). Therefore, the cross-sectional regressions in Panels A and B suggest that differences in government size are not a major determinant of the volatility over the thirty-year period we are looking at.

It is also worth noting that the (instrumented) effect of initial institutions on volatility

\footnotetext{
${ }^{21}$ To save space we do not report the first-stage relationship for institutions, which is very similar to the regressions reported in Table 2 (though not identical since other variables are now also included in the first stage).
} 
we estimate in these two panels are very similar to the estimates in Table 2. For example, in Table 2, the effect of initial constraint on the executive on volatility is around -0.8 in models that do not control for initial income, and around -1.6 in models that control for initial income. When we also control for government size as in Table 3, the effect of initial institutions on volatility is very similar: the coefficient is now -0.82 without initial income and -1.56 with initial income.

The models reported in Panels A and B are based on the estimation of equation (1), which looks at the relationship between volatility and government size over the thirtyyear period (1970-97). As discussed above, some countries may experience short periods of large government spending, causing major crises, while during other periods they may have offsetting low spending, thus resulting in average government size similar to that in other countries. To investigate this possibility, in Panels $\mathrm{C}$ and $\mathrm{D}$, we estimate the panel regression equation (2). The first three columns show the effect of government size without controlling for institutions. When we add institutions, the government size variable is again found not to be a key determinant of volatility. Instead, there is a robust relationship between initial institutions and subsequent volatility between 1970 and 1997.

Table 4 repeats the same exercise as Table 3, but using log inflation rather than government consumption. We use the log of average inflation rather than the level of inflation, since the relationship between volatility and inflation is stronger when we use the log specification and less affected by outliers. Panels A and B estimate equation (1), with and without initial income. The basic patterns are the same. Throughout, there is a robust effect of institutions on volatility, with very similar coefficients to those found in Table 2 (in instrumented regressions using the full sample, the coefficient is -0.83 without initial income and -1.57 with initial income). There is no evidence that inflation matters for volatility in the full sample of former colonies, either in the cross-section or in the 5-year panel, although it is significant in some specifications for the sample of former colonies above median world income. 
Table 5 turns to exchange rate overvaluation, and uses the index of exchange rate overvaluation constructed by David Dollar (1992) and updated by Easterly and Levine (2002). ${ }^{22}$ The first three columns show a strong relationship between real exchange rate overvaluation when the importance of institutions is not taken into account. When the next column includes institutions in the regression, the effect of overvaluation remains significant. Initial institutions also continue to have a large and statistically-significant effect on volatility, with a coefficient about $1 / 4$ less than the corresponding estimate without controlling for exchange rate overvaluation. ${ }^{23}$ When we also control for initial income per capita in Panel B, the effect of overvaluation is still significant, and initial constraint on the executive is also highly significant, but with a smaller coefficient than our baseline estimates. These results suggest that misaligned exchange rates are a mediating channel for the effect of institutions on volatility, but probably not the primary mediating channel.

Overall, the results presented in this subsection suggest that the historically-determined component of institutions has a first-order effect on volatility, and neither inflation nor government consumption (nor the other standard macro variables we examined) seem to be the main mediating channel, though exchange rate overvaluation is typically correlated with volatility. Our interpretation of these results is that a fundamental determinant of thirty-year volatility differences is institutional differences across countries, and that institutional differences create economic instability through a variety of microeconomic channels as well as the often-emphasized macroeconomic channels.

\footnotetext{
${ }^{22}$ Due to data availability, we use the average value of this overvaluation index from 1960 to 1998 , generously provided by Bill Easterly and Ross Levine. Because we only have an average value for the entire period, we cannot instrument using lagged values as in Tables 3 and 4 . We have also checked the results using the variability of overvaluation from Dollar (1992), but as this does not change our results we omit it here from the discussion.

${ }^{23}$ The coefficient on institutions in Table 3 is -0.83 , but once we limit the sample to the former colonies for which we have data on real exchange rate overvaluation, the coefficient on institutions drops to -0.69. The coefficient in Table $5-0.49$.
} 


\subsection{Institutions Versus Macroeconomic Policies: Crises}

Table 6 presents a number of specifications that look at the impact of macro variables and institutions on the severity of crises, measured by the largest output drop during the sample. Each of the three different panels refers to one of the three macro variables we considered so far. In all cases, our measure of institutions, average constraint on the executive in 1950, 1960 and 1970, is instrumented by settler mortality (See Appendix Table A4 for results using constraint on the executive in 1970).

The picture that emerges from this table is similar to that from Tables 3, 4 and 5 . In most specifications there is a substantial effect of initial constraint on the executive on severity of crises, and this effect remains statistically significant at the conventional levels even when we control for initial income. In most specifications, the effect of initial institutions is again comparable to the baseline results in Table 2 (in Table 2, the coefficient on institutions in the 2SLS regression on worst output performance is around -2.5 when we do not control for initial income, and around -5 when we control for initial income; the range of estimates in this table are tightly around these values). We also find that government consumption and log average inflation do not appear to have an effect on the severity of crises when we take the influence of institutions into account. In contrast to our results with volatility, the extent of overvaluation of the real exchange rate is also insignificant, and only slightly reduces the effect of institutions on the severity of crises.

These results confirm the conclusion of the previous section that there appears to be a close a link between institutions and economic instability, most likely not mediated primarily through the standard macroeconomic variables.

\subsection{Institutions Versus Macroeconomic Policies: Economic Growth}

Table 7 looks at the relationship between macroeconomic variables and institutions, on the one hand, and economic growth, on the other. As in Table 6, the three panels 
of the table refer to three different macro variables, and in all cases we also include institutions, average constraint on the executive in 1950, 1960 and 1970, instrumented by our historical instruments (See Appendix Table A5 for results using constraint on the executive in 1970).

In the full sample of excolonies (odd-numbered columns), we find a significant effect of initial institutions on growth, no effects from government consumption, some effects from inflation, and stronger effects from overvaluation. When we limit the sample to excolonies above median world income, and especially when we also control for initial income, the effect of institutions on growth is weaker. Our interpretation is the same as the one we offered above: much of the divergence in income happened between 1750 and 1950, when countries with good institutions grew rapidly, and those with extractive institutions failed to do so (Acemoglu, Johnson and Robinson, 2002a). By 1970, much of this process of adjustment was complete, and the effect of institutions on further growth is correspondingly weaker. Moreover, the sample of former colonies above median world income is relatively small, and exhibits limited variation in growth. In this light, these weaker results may not be so surprising.

\section{Institutions and Volatility: Robustness and Mechanisms}

The previous section documented a strong relationship between institutions and economic volatility, and presented evidence suggesting that this relationship was not mediated through any of the standard macroeconomic variables. In this section, we investigate the relationship between institutions and volatility further, and show that it is robust to controlling for a variety of other potential determinants of economic instability. We then investigate the empirical validity of some potential mechanisms via which institutions might be affecting volatility. 


\subsection{Robustness}

Table 8 reports regressions of volatility on institutions, while also controlling for a number of potential determinants of volatility. In particular, in various columns, we control for all the macro variables together, the initial level of education, the importance of financial intermediation, the variability of terms of trade times the share of exports, and we also estimate models excluding outliers.

In columns 1 and 2 of Panel A of Table 8, we add all the macro variables together, with or without initial income. Initial constraint on the executive has a negative effect on volatility. Without controlling for initial income, this effect is significant, but somewhat smaller than in Table 2. When we also control for initial income, the standard error increases but the coefficient on institutions remains very similar in size to the coefficients reported in Table 2. The effect of initial income is not significant. Jointly, the macro variables are insignificant as shown by the p-value. In Panel B, we run the same regressions, but this time in a manner similar to the panel regression in equation (2), with each observation corresponding to a 5-year period. Now the effects of the macro variables are even weaker, and the constraint on the executive is consistently significant, with very similar coefficients to before (again the standard errors in this lower panel are clustered by country).

In columns 3 and 4 we control for years of schooling in 1970 (from Barro and Lee, 1993). This is a useful specification, since, as we argue in Acemoglu, Johnson and Robinson (2001), historical institutions determined various components of investments, including investments in human capital, so we expect education levels in 1970 to be correlated with the historically-determined component of institutions. It is then important to know whether the effect of institutions on volatility is working primarily through some educational mechanism. When we include human capital, constraint on the executive continues to have a negative effect, similar in magnitude to our previous results, but it is no longer significant. This is because human capital and constraint on the executive are highly correlated. But, the years of schooling variable is very far from being significant, 
and in fact, it has the wrong sign. In the lower panel where we run regressions for the 5-year panel, the human capital variable continues to be insignificant, but now the initial constraint on the executive is significant at the 10 percent level, with a similar coefficient to that found in Table 2. These results suggest that the effect of initial constraint is not working through an educational channel.

In columns 5 and 6 we add (log of) the ratio of real M2 to GDP as a measure of the importance of financial intermediation (see Easterly, Islam and Stiglitz, 2000, for the use of this variable in this context). Many macroeconomists emphasize weak financial intermediation as a primary cause of economic volatility. Again we find no strong evidence supporting this claim. The financial intermediation variables are not significant, and initial constraint on the executive is significant in most specifications. ${ }^{24}$

In columns 7 and 8, we control for other determinants of variability, including terms of trade variability, the export share of the GDP, and the interaction between these two variables. In columns 9 and 10 we also exclude some outliers. The results are very similar to our baseline results, showing that the effect of the historically-determined component of institutions on volatility is robust, and is not simply driven by some other sources of output variability correlated with institutions. ${ }^{25}$

Table 9 further checks the robustness of our results in two ways: with additional control variables and by restricting the sample. Panel A adds additional control variables. La Porta et al. (1998) have argued for the importance of investor protection, and Johnson et al. (2000) found that investor protection measures were significantly correlated with exchange rate depreciations and stock market declines across emerging markets in 1997-98. In columns 1 and 2, we add the measure of de jure shareholders'

\footnotetext{
${ }^{24}$ This is consistent with the results in Johnson, McMillan and Woodruff (2002), who, in a different context, also find that property rights appear to matter more than the availability of external finance.

${ }^{25}$ We have also run the regressions as in Table 8 using a different measure of institutions, average protection against expropriation risk, which was our main variable in Acemoglu, Johnson and Robinson (2001). This variable refers to a later period and hence is not ideal for our purposes here. However, as we are instrumenting for institutions with historical variables, this may not matter too much. In any case, the results in with this alternative specification are very similar to those in Table 8 , and show a robust effect of institutions on volatility.
} 
rights from La Porta et al. (1998). ${ }^{26}$ These de jure measures do not appear to be related to volatility (although the sample size is now quite small), while the coefficient on initial constraint on the executive is essentially the same as in Table 2. Columns 3 and 4 show similar results for de jure creditors' rights. The results are similar, but now when we also include log initial GDP per capita (column 4), the cofficient on initial constraint on the executive is no longer significant at the 5 percent level. Clearly investor protection and creditors' rights are closely linked to overall property rights enforcement and constraint on the executive. Nevertheless, they capture only one dimension of "institutional" differences, which we believe are much broader, and include various other aspects of the organization of society. These results therefore suggest that what is important for volatility (and more generally, for economic performance) is not simply de jure investor or creditor protection, but a broader range of institutions, including property rights protection for a broader cross-section of society, constraints on politicians and elites, arrangements to manage social divisions and ensure political stability, and the "rule of law", which determine whether these de jure rights are enforced. ${ }^{27}$

Columns 5 and 6 add the share of primary exports in GDP, a basic measure of openness and exposure to shocks, from Sachs and Warner (1997). This variable also has little effect on our main results. Similarly, including latitude, as a common proxy for geographic influences on economic outcomes, has little impact on initial constraint on the executive, and latitude itself is insignificant (see columns 7 and 8).

Panel B further checks our results by limiting the sample of countries under consideration. Columns 9 and 10 report regressions using only Common Law countries, i.e., those that inherited or adopted a legal system based on British common law (see La Porta et al., 1998). Columns 11 and 12 run the regressions just for former colonies, and

\footnotetext{
${ }^{26}$ We refer to these as "de jure" measures, since these measures do not take into account how well these legislated rights are enforced. Note also that these measures are only available for countries that are relatively open to capital flows. For example, we do not have this information for many African countries.

${ }^{27}$ La Porta et al (1998) also suggest that effective investor protection must be enforced through courts or regulation, and Johnson et al (2000) find significant effects for the rule of law both directly and in interaction with de jure investor protection measures.
} 
drop the "Neo-Europes" (USA, Canada, Australia and New Zealand). The results for these various subsamples are similar to our baseline results.

One concern with our basic results is whether they simply reflect very large crises and volatility in African or other poor nations which also have weak institutions. If this were the case, one might think that institutions matter for differences in volatility between poor (African) and rich (non-African) nations, but have less effect on volatility among richer (non-African) nations. The results so far show that there is a strong relationship between the historically-determined component of institutions and volatility even among nations above median world income (see Tables 1 through 7). Moreover, Table 1 showed that even excluding Africa, there is a statistical relationship between the historicallydetermined component of institutions and the level of income or economic growth. To investigate this issue further in the context of volatility, columns 13 and 14 drop all the African countries. The coefficient on initial constraint on the executive remains significant and similar in size to our baseline result in Table 3. This, together with the results reported so far, suggests that our results are not driven simply by the contrast between poor and rich nations, and institutional differences even among relatively rich nations matter for volatility. Finally, columns 15 and 16 report results just for countries below the median world per capita income level, where we find a similar relationship, suggesting that the link between institutions and volatility is there both among relatively poor and relatively rich nations.

Another dimension of robustness is whether the relationship between institutions and instability is being driven by events in some specific decades. To investigate this issue, Table 10 looks at the relationship between our measure of institutions (which refers to the average constraint on the executive in 1950, 1960 and 1970), and the three macro outcomes of interest, in each of the decades of the 1970s, 1980s and 1990s. The three panels refer to the three decades, while pairs of columns look at different outcomes, and columns are paired with and without initial income. The results show a significant relationship between institutions and volatility, and also between institutions 
and crises in the 1970s and 1980s. These relationships are weaker in the 1990s. In contrast, the relationship between institutions and growth is stronger and significant in the 1990s (as well as in the 1980s, but not in the 1970s). A possible interpretation is that during the $1990 \mathrm{~s}$, countries with weak institutions did not experience much growth, and therefore had no significant volatility. ${ }^{28}$ This interpretation highlights that countries with weak institutions may go through extended periods (as long as a decade) of reasonably high growth, but this growth experience is often associated with high volatility. These countries may also experience long episodes of very low growth (and by implication, little volatility) as seems to have been the case during the 1990s.

\subsection{Proximate Mechanisms: Global Shocks, Institutions and Volatility}

What is the link between institutions and volatility? There are many levels at which we can try to answer this question. At the simplest level, we can investigate whether the relationship occurs because countries with weaker institutions suffer much more in the face of economic shocks.

More specifically, we can imagine each country going through output fluctuations due to "fundamental reasons". We may then conjecture that when output is low in an institutionally-weak society, there will be increased conflict and significant forces reducing output further. Therefore, output may drop by much more than it would have done due to the underlying fundamental reasons. Unfortunately, we cannot directly test for this possibility, since we do not observe the "fundamental" output fluctuations.

However, we can investigate whether institutionally-weak societies suffer more volatility and larger output drops during periods of world economic slowdown and recession. This link between world output shocks and economic problems and institutionally-weak societies is very similar to Rodrik's (1999) interpretation of why growth slowed down more in some countries.

\footnotetext{
${ }^{28}$ Note, however, that our data on volatility are only through 1997 , so our results do not include the "Asian financial crisis" of 1997-98.
} 
The results already presented in Table 10 suggest that the link between global shocks and instability may not be very strong. The early 1990s were a period of disappointing output growth, but the relationship between institutions and volatility is weak in the 1990s.

To investigate this issue more carefully, in Table 11, we estimate models of the following form:

$$
X_{c, t-1, t}=Q_{c, t-1, t}^{\prime} \cdot \alpha+\beta \cdot I_{c, t=0}+\eta \cdot g_{t, t-1} \cdot I_{c, t=0}+\theta \cdot \ln y_{c, t-1}+\delta_{t-1, t}+\varepsilon_{c, t-1, t},
$$

where all the variables are defined as before, and in particular, $X_{c, t-1, t}$ refers to macro outcomes between time $t-1$ and $t$, and here time periods are taken to be five-year periods. The $\delta_{t-1, t}$ terms denote time effects, and $I_{c, t=0}$ is our measure of initial institutions.

The variable of interest here is the interaction term between the world growth rate, $g_{t, t-1}$, and country institutions. A significant effect from these interaction terms would indicate that institutionally-weak societies have a greater propensity to experience macroeconomic problems (high volatility or low growth) during periods of slow world growth. As before we instrument for institutions, $I_{c, t=0}$, using our historical instruments, and now we also instrument for the interaction between institutions and world aggregates, the $g_{t, t-1} \cdot I_{c, t=0}$ terms, using interactions between world aggregates and our instruments. The variables are de-meaned, so the main effect of institutions in this regression is evaluated at the mean value of the sample. We also cluster the standard errors by country.

As an alternative specification we estimate:

$$
X_{c, t-1, t}=Q_{c, t-1, t}^{\prime} \cdot \alpha+\eta \cdot g_{t, t-1} \cdot I_{c, t=0}+\theta \cdot \ln y_{c, t-1}+d_{c}+\delta_{t-1, t}+\varepsilon_{c, t-1, t},
$$

which replaces the main effect of institutions by a full set of country dummies.

Table 11 focuses on two global variables: the growth rate of world output and of world trade. The results show no evidence that there is a significant interaction term indicating greater propensity of institutionally-weak societies to run into crises during periods of world economic slowdown (or expansion) or greater growth of world trade. 
The interaction terms are usually insignificant when the dependent variable is volatility

of output. In contrast, in columns 5 and 6 where the dependent variable is country growth, we find significant interactions between world growth and initial institutions. This suggests that when the world economy slows down, institutionally-weak societies slow down more than others. But these growth effects do not translate into greater volatility for these institutionally-weak societies during periods of world economic slowdown (columns 1, 2, 3 and 4).

We conclude that the proximate mechanism for the relationship between institutions and volatility is not primarily the propensity of institutionally-weak societies to run into crises during periods of world recession or other major global events. Instead it is likely that it is the inability of institutionally-weak societies to deal with their own idiosyncratic economic and most likely political problems that underlies their economic instability. In the next subsection, we briefly look at a potential mechanism along these lines.

\subsection{State Failures and Volatility}

This subsection provides a preliminary investigation of whether political crises could be a mediating mechanism for the impact of weak institutions on economic volatility, as suggested by some of the theoretical ideas in subsection 3.1. We believe that the link between political crises (state failures) and economic instability is important to understand the relationship between institutions and volatility. A more in-depth study, using more detailed measures of political crises, is necessary, but beyond the scope of the current paper. We leave this for future research.

Here we simply use the dataset of the State Failure Task Force (1998) to code periods of "state failures", that is, major political crises, such as civil wars, revolutions, violent infighting, etc., between different factions. In Panel A of Table 12, we first look at the relationship between state failures (in various periods) and initial constraint on the executive, instrumented by our historical variables. Countries with weak institutions at 
the beginning of the sample were more likely to suffer state failures, though, somewhat surprisingly, this effect is not always statistically significant.

We next turn to the relationship between state failures and volatility or growth. More specifically, we estimate models similar to equations (1) and (2), with the only difference that instead of the macroeconomic variables, $Q$, we include a dummy for state failure during the period, $S$.

The results from this exercise are reported in Panels $\mathrm{B}$ and $\mathrm{C}$ of Table 12 . In the cross-section, state failures have the right sign, but are not significant determinants of volatility and growth (but they are almost significant for the severity of crises, i.e., worst output drop). We conjecture that this may be because a dummy for state failure is too crude to capture the severity of various political problems, while also leaving out some important political crises that may matter for economic instability.

In any case, when we look at the 5-year observations in Panel C, we find that state failures are now typically significant determinants of macroeconomic problems and volatility. Although state failures are significant, the coefficient on initial institutions is reduced only a little. This suggests that the major state failures identified in this dataset are not the main channel leading to volatility. One possibility is that these state failures may be "the tip of a much larger iceberg", and there may be other less violent or less notable political crises that lead to episodes of volatility and low growth. Future work using more detailed measures of political crises is necessary to further investigate whether more general political crises could be a major mediating channel for the effect of institutions on economic volatility.

\section{Conclusion}

Why have many LDCs suffered very high volatility and severe crises over the postwar period? The standard answer is that they have followed unsustainable and distortionary macroeconomic policies. In this paper, we developed the argument that the fundamental cause of post-war instability is institutional. Using the historically-determined 
component of institutions, we documented a strong relationship between institutions and volatility (as well as a link between institutions and crises or growth). Once we take the effect of institutions on volatility into account, there seems to be little major role for the standard macroeconomic variables emphasized in the literature and by the Washington consensus. The only "macro" variable which appears to play an important mediating role is overvaluation of the real exchange rate, which is consistent with our discussion of the Ghanaian case, where real overvaluation was used as a method of expropropriation or redistribution.

Overall, we interpret our findings as suggesting that the major causes of the large cross-country differences in volatility are institutional, and none of the standard macroeconomic variables appear to be the primary mediating channels through which institutional causes lead to economic instability. These macroeconomic problems, just like the volatility and the disappointing macroeconomic performance suffered by these countries, are symptoms of deeper institutional causes.

This perspective does not suggest that macroeconomic policies do not matter. The point we believe and want to emphasize is that there are deeper institutional causes leading to economic instability, and these institutional causes lead to bad macroeconomic outcomes via a variety of mediating channels. Distortionary macroeconomic policies are part of these channels, or in other words, they are part of the "tools" that groups in power use in order to enrich themselves and to remain in power. But they are only one of many possible tools, and a variety of complex factors, which we do not currently understand, determine which of these tools get used in various circumstances. An interesting possibility implied by this perspective is a seesaw effect: preventing the use of a specific macro distortion will not necessarily cure the economic instability problems, since underlying institutional problems may manifest themselves in the use of some other tools by politicians and elites to achieve their objectives.

Our results also did not specifically pinpoint the exact mechanism via which institutional weaknesses translate into economic instability. They are consistent with the 
notion that political crises ("state failures") may be important, but our evidence here is more circumstantial. More research on these issues is clearly necessary. 


\section{REFERENCES}

Acemoglu, Daron, Simon Johnson and James A. Robinson (2001) "Colonial Origins of Comparative Development: An Empirical Investigation," American Economic Review, 91, 1369-1401.

Acemoglu, Daron, Simon Johnson and James A. Robinson (2002a) "Reversal of Fortune: Geography and Institutions in the Making of the Modern World Income Distribution," forthcoming Quarterly Journal of Economics.

Acemoglu, Daron, Simon Johnson and James A. Robinson (2002b) "The Rise of Europe: Atlantic Trade, Institutional Change and Economic Growth," Unpublished.

Acemoglu, Daron and James A. Robinson (2000) "Political Losers as a Barrier to Economic Development," American Economic Review, 90, 126-130.

Acemoglu, Daron and James A. Robinson (2001) "A Theory of Political Transitions," American Economic Review, 91, 938-963.

Acemoglu, Daron and James A. Robinson (2002) "Economic Backwardness in Political Perspective," NBER Working Paper No. 8831.

Acemoglu, Daron and Fabrizio Zilibotti (1997) "Was Prometheus Unbound by Chance? Risk, Diversification and Growth," Journal of Political Economy, 105, 1167-1200.

Apter, David E. (1972) Ghana in Transition, Princeton; Princeton University Press.

Austin, Dennis (1964) Politics in Ghana, 1947-1960, Oxford UK; Oxford University Press.

Bardhan, Pranab (1984) The Political Economy of Development in India, Basil Blackwell, Oxford.

Benhabib, Jess and Aldo Rustichini (1996) "Social Conflict and Growth" Journal of Economic Growth, 1, 125-142.

Barro, Robert J. (1991) "Economic Growth in a Cross Section of Countries," 
Quarterly Journal of Economics, 106, 407-433.

Barro, Robert J. and Lee, Jong-Wha (1993) "International Comparisons of Educational Attainment," Journal of Monetary Economics, 32, 363-394.

Bates, Robert H. (1981) Markets and States in Tropical Africa, Berkeley; University of California Press.

Besley, Timothy (1995) "Property Rights and Investment Incentives: Theory and Evidence from Ghana," Journal of Political Economy, 103, 903-937.

Blanchard, Olivier J. and John Simon (2002) "The Long and Large Decline in US Output Volatility," forthcoming in the Brookings Papers on Economics Activity.

Cabellero, Ricardo J. (2001) Macroeconomic Volatility in Reformed Latin America: Diagnosis and Policy Proposals, Washington; Inter-American Development Bank.

Caballero, Ricardo J. and Rudiger Dornbusch (2002) "A Plan for Argentina," http://web.mit.edu/caball/www/ARGENTINA22802.pdf.

Caballero, Ricardo J. and A. Krishnamurthy (2000) "Emerging Market Crises; An Asset Markets Perspective," Unpublished, Department of Economics, MIT.

Chang, Roberto and Andres Velasco (2002) "A Model of Financial Crisis in Emerging Markets,." forthcoming Quarterly Journal of Economics.

Collier, David and Ruth Berins Collier (1991) Shaping the Political Arena: Critical Junctures, the Labor Movement, and Regime Dynamics in Latin America, Princeton; Princeton University Press.

Crosby, Alfred (1986) Ecological Imperialism: The Biological Expansion of Europe, New York; Cambridge University Press.

Curtin, Philip D. (1989) Death by Migration: Europe's Encounter with the Tropical World in the 19th Century, New York; Cambridge University Press.

Curtin, Philip D. (1998) Disease and Empire: The Health of European Troops in the Conquest of Africa, New York; Cambridge University Press.

Curtin Philip D. (2000) The World and the West: the European Challenge and Overseas Response in the Age of Empire, Cambridge University Press, Cambridge. 
Denizer, Cevzet, Murat Iyigun and Ann Owen. (2001) "Finance and Macroeconomic Volatility," World Bank Discussion Paper.

Díaz Alejandro, Carlos F. (1970) Essays on the Economic History of the Argentine Republic, Yale University Press, New Haven CT.

Dollar, David (1992) "Outward Oriented Developing Economies Really do Grow More Rapidly," Economic Development and Cultural Change, 40, 523-544.

Dornbusch, Rudiger, Ilan Goldfajn, and Rodrigo Valdes (1995) "Currency Crises and Collapses" Brookings Papers on Economic Activities, pp. 219-294.

Easterly, William (2001) "The Lost Decades: The Developing Countries Stagnation in Spite of Policy Reform," Journal of Economic Growth, 9, 135-157.

Easterly, William, Roumeen Islam, and Joseph Stiglitz, (2000), "Shaken and Stirred, Explaining Growth Volatility," Annual Bank Conference on Development Economics, The World Bank, April.

Edwards, Sebastián (1989) "The International Monetary Fund and the Developing Countries: A Critical Evaluation," Karl Brunner and Allan H. Meltzer eds. IMF Policy Advice, Market Volatility, Commodity Price Rules and Other Essays, Amsterdam; North-Holland.

Eichengreen, Barry and Michael D. Bordo (2002) "Crises Then and Now: What Lessons from the Last Era of Financial Globalization?" NBER Working Paper 8716, January.

Frieden, Jeffry (2001) The Modern World Economy, 1870-2000, Unpublished Book manuscript, Department of Government, Harvard University.

Gerchunoff, Pablo (1989) "Peronist Economic Policies, 1946-1955," in Rudiger Dornbusch and Guido di Tella eds. The Political Economy of Argentina, 1946-1983, University of Pittsburg Press, Pittsburg PA.

Germani, Gino (1962) Politica y Sociedad en una Epoca de Transicion, de la Sociedad Tradicional a la Sociedad de Masas, Buenos Aires; Editorial Paidos.

Gibson, Edward L. (1997) "The Populist Road to Market Reform: Policy and 
Electoral Coalitions in Mexico and Argentina," World Politics, 59,

Gibson, Edward L., Ernesto F. Calvo and Tulia G. Falleti (2001) "Reallocative Federalism: Overrepresentation and Public Spending in the Western Hemisphere," Unpublished, Department of Political Science, Northwestern University.

Gutierrez, Hector (1986) "La Mortalite des Eveques Latino-Americains aux XVIIe et XVIII Siecles," Annales de Demographie Historique, 29-39.

Hall, Robert E. and Charles I. Jones (1999) "Why Do Some Countries Produce so Much More Output per Worker than Others?" Quarterly Journal of Economics, 114, 83-116.

Herbst, Jeffrey I. (1993) The Politics of Reform in Ghana, 1982-1991, Berkeley; University of California Press.

Herbst, Jeffrey I. (2000) States and Power in Africa: Comparative lessons in Authority and Control, Princeton; Princeton University Press.

Johnson, Simon, Peter Boone, Alasdair Breach, and Eric Friedman (2000) "Corporate Governance in the Asian Financial Crisis," Journal of Financial Economics, Volume 58, Nos. 1-2, October/November, 141-186.

Johnson, Simon, John McMillan, and Christopher Woodruff (2002) "Property Rights and Finance," American Economic Review, forthcoming.

Jones, Eric L. (1981) The European Miracle: Environments, Economies and Geopolitics in the History of Europe and Asia, Cambridge University Press, Cambridge UK.

Leith, J. Clark and Michael F. Lofchie (1993) "The Political Economy of Structural Adjustment in Ghana," in Robert H. Bates and Anne O. Krueger eds. Political and Economic Interactions in Economics Policy Reform: Evidence from Eight Countries, Cambridge MA; Basil Blackwell.

Lizzeri, Alessandro and Nicola Persico (2001) "The Provision of Public Goods Under Alternative Electoral Incentives," American Economic Review, 91, 225-245.

Kaminsky, Graciela L. and Carmen M. Reinhart (1999) "The Twin Crises: 
The Causes of Banking and Balance of Payments Problems," American Economic Review, 89, 473-500.

Knack, Stephen and Philip Keefer (1995) "Institutions and Economic Performance: Cross-Country Tests using alternative measures," Economics and Politics, 7, 207-227.

Kraay, Art and Jaume Ventura (2000) "Comparative Advantage and the CrossSection of Business Cycles," Unpublished, Department of Economics, MIT.

Krueger, Anne O. (1993) Political Economy of Policy Reform in Developing Countries, Cambridge; MIT Press.

Krugman, Paul (1979) "A Model of Balance of Payments Crises," Journal of Money Credit and Banking, 11, 311-325.

Krusell, Per and José-Victor Ríos-Rull (1996) "Vested Interests in a Theory of Growth and Stagnation," Review of Economic Studies, 63, 301-329.

La Porta, Rafael, Florencio Lopez-de-Silanes, Andrei Shleifer and Robert W. Vishny (1998) "Law and Finance," Journal of Political Economy, 106, 1113-1155.

Maddison, Angus (2001) The World Economy: A Millenial Perspective, OECD, Paris.

Mauro, Paulo (1995) "Corruption and Growth," Quarterly Journal of Economics, CX, 681-712.

Mazzuca, Sebastián (2001) "Southern Cone Leviathans. State Formation in Argentina, Brazil, Chile, and Uruguay," Unpublished PhD Dissertation, Department of Political Science, Berkeley.

McConnell, Margaret M. and Gabriel Perez-Quiros (2000) "Output Fluctuations in the United States: What has Changed since the Early 1980's"' American Economic Review, 90, 1464-1476.

Mora y Araujo, Manuel and Ignacio Llorente (1980) El Voto Peronista, Buenos Aires; Editorial Sudamericana.

North, Douglas C. (1981) Structure and Change in Economic History, W.W. 
Norton \& Co., New York.

North, Douglass C. and Richard P. Thomas (1973) The Rise of the Western World: A New Economic History, Cambridge University Press, Cambridge UK.

Olson, Mancur C. (1982) The Rise and Decline of Nations, Yale University Press, New Haven, CT.

Owusu, Maxwell (1970) Use and Abuses of Power: A Case Study of Continuity and Change in the Politics of Ghana, University of Chicago Press, Chicago IL.

della Paolera, Gerardo and Alan M. Taylor (2001) Straining at the Anchor: The Argentine Currency Board and the Search for Macroeconomic Stability 1880-1935, Chicago; University of Chicago Press.

Parente, Stephen L. and Edward C. Prescott (1999) "Monopoly Rights: A Barrier to Riches," American Economic Review, 89, 1216-1233.

Pellow, Deborah and Naomi Chazan (1986) Ghana: Coping with Uncertainty, Boulder CO; Westview Press.

Raddatz, Claudio (2002) "Liquidity Needs and Vulnerability to Financial Underdevelopment," Unpublished, Department of Economics, MIT.

Ramey, Gary and Valerie Ramey (1995) "Cross-Country Evidence on the Links Between Volatility and Growth," American Economic Review, 85, 1138-1151.

Rock, David J. (1987) Argentina 1516-1987: From Spanish Colonization to Alfonsin, Berkeley; University of California Press.

Rodrik, Dani (1997) "Democracy and Economic Performance,"

http://ksghome.harvard.edu/ .drodrik.academic.ksg/demoecon.PDF.

Rodrik, Dani (1999) "Where Did All the Growth Go? External Shocks, Social Conflict and Growth Collapses," Journal of Economic Growth,

Rodrik, Dani (2002) "Reform in Argentina, Take Two: Trade Rout," The New Republic.

Roe, Mark J. (1998) "Essays: Backlash," Columbia Law Review, 98, 217-241.

Sachs, Jeffrey D. (1990) "Social Conflict and Populist Policies in Latin America," 
in R. Brunetta and C. Dell'Aringa eds. Labor Relations and Economic Performance, NYU Press, New York.

Sachs, Jeffrey D. and Andrew Warner (1997). "Fundamental Sources of LongRun Growth," American Economic Review, Papers and Proceedings, May.

Samuels, David and Richard Snyder (2001) "The Value of a Vote: Malapportionment in Comparative Perspective," British Journal of Political Science, Volume 31, Issue 4, October, 651-671.

Samuels, David and Richard Snyder (2002) "Legislative Malapportionment in Latin America: Historical and Comparative Perspectives," Unpublished.

Sawers, Larry (1996) The Other Argentina: The Interior and National Development, Boulder; Westview Press.

Shleifer, Andrei (1997) "Government in Transition," European Economic Review, 41, 385-410.

State Failure Task Force (1998) "State Failure Task Force Report: Phase II Findings," prepared by Daniel C. Esty, Jack A. Goldstone, Ted Robert Gurr, Barbara Huff, Marc Levy, Geoffrey D. Dabelko, Pamelo T, Surko, and Alan N. Unger, 31 July.

Stock, James and Mark Watson (2002) "Has the Business Cycle Changed and Why?" forthcoming in the NBER Macroeconomic Annual.

Taylor, Alan M. (1998) "On the Costs of Inward Looking Development: Price Distortions, Growth and Divergence in Latin America," Journal of Economic History, $57,147-184$.

Tommasi, Mariano, Sebastián Saiegh and Pablo Sanguinetti (2001) "Fiscal Federalism in Argentina: Policies, Politics and Institutional Reforms," Economía, 1, 157-211.

Tornell, Aaron and Andres Velasco (1992) "The Tragedy of the Commons and Economic Growth: Why Does Capital Flow from Poor to Rich Countries?" Journal of Political Economy,100, 1208-31.

Voth, Hans-Joachim (2002) "Why was Stock Market Volatility so High During 
the Great Depression? Evidence from 10 Countries During the Interwar Period." CEPR Discussion Paper, DP3254.

Weisman, Carlos (1987) The Reversal of Development in Argentina, Princeton; Princeton University Press.

Williamson, John (1990) Latin American Adjustment: How Much Has Happened? Washington DC; Institute for International Economics. 


\section{Table 1}

Income, Growth and Institutions

\begin{tabular}{cccccccc}
\hline \hline & Excolonies & \multicolumn{3}{c}{ Excolonies } \\
Excolonies & above median & Excolonies & Excolonies & above median & Excolonies \\
Sample & world income & without Africa & Sample & world income & without Africa \\
& $(1)$ & $(2)$ & $(3)$ & $(4)$ & $(5)$ & $(6)$ & $(5)$ \\
\hline
\end{tabular}

Panel A: Dependent variable is log GDP per capita in 1995

$\begin{array}{cccc} & & \text { Two-St } \\ \text { Average Protection Against } & 0.96 & 0.50 & 0.56 \\ \text { Expropriation, 1985-95 } & (0.17) & (0.08) & (0.10)\end{array}$

Initial Constraint on Executive

$\begin{array}{ccc}0.62 & 0.46 & 0.57 \\ (0.11) & (0.16) & (0.18)\end{array}$

First Stage for Measure of Institutions

Log settler mortality

$-0.58$

$(0.13)$

$-1.10$

$(0.26)$

$-1.21$

$-0.91$

$-1.15$

$(0.36)$

$-1.25$

$(0.24)$

$(0.16)$

0.41

0.34

0.33

0.29

R-Squared

Number of Observations

0.24
64
$\begin{gathered}\text { Excolonies } \\ \text { Sample }\end{gathered}$

(7)

0.44

37

68

23

35

Excolonies above median world income

Excolonies without Africa

(8)

(9)

Excolonies
Sample

Excolonies

above median world income

Excolonies without Africa

Panel B: Dependent variable is average annual growth of GDP per capita, 1970-97

Two-Stage Least Squares

Initial Constraint on Executive

0.75

$(0.22)$

0.50

$(0.32)$

0.50

1.57

0.98

1.05

$(0.31)$

$(0.71)$

$(0.60)$

$(0.58)$

Log GDP per capita in 1970

$-1.58$

$-2.04$

$-1.42$

(1.00)

(2.46)

First Stage for Measure of Institutions

Log settler mortality

$$
-0.95
$$

(0.16)

$-1.35$

$-1.31$

$-0.54$

$-0.97$

$(0.20)$

$(0.35)$

$-0.98$

$(0.32)$

(0.35)

0.84

$(0.27)$

1.21

$(0.40)$

Log GDP per capita in 1970

0.37

0.44

0.30

0.45

$(0.56)$

0.63

$(0.39)$

R-Squared

63

25

35

61

0.53

0.35

Standard errors are in parentheses. All regressions are cross-sectional with one observation per country. In Panel A the dependent variable is the level of log GDP per capita in 1995 and in Panel B it is the average annual growth rate of GDP per capita from 1970 to 1997; both are from the World Bank. The independent variable in columns 1,2 and 3 of Panel A is average protection against expropriation risk, 1985-95, from Political Risk Services, as used in Acemoglu, Johnson and Robinson (2001); a higher score indicates more protection. In all other columns the independent variable, Initial Constraint on Executive, is average constraint on executive in 1950, 1960 and 1970, which is an average of the Polity score in each year; countries that are still colonies in a particular year are assigned a score of 1 . In both panels the measure of institutions is instrumented using log settler mortality before 1850 (where mortality is per 1000 per annum with replacement).

The Excolonies Sample includes all former colonies of European Powers for which Acemoglu, Johnson and Robinson (2001) report data. Alternative samples are excolonies above median world per capita income in 1970, as measured by Summers-Heston and reported in Barro and Lee (1993), and without Gabon, and excolonies without any African countries. For more detailed data definitions and sources see Appendix Table 1. 
Table 2

Institutions, Macroeconomic Policies and Outcomes

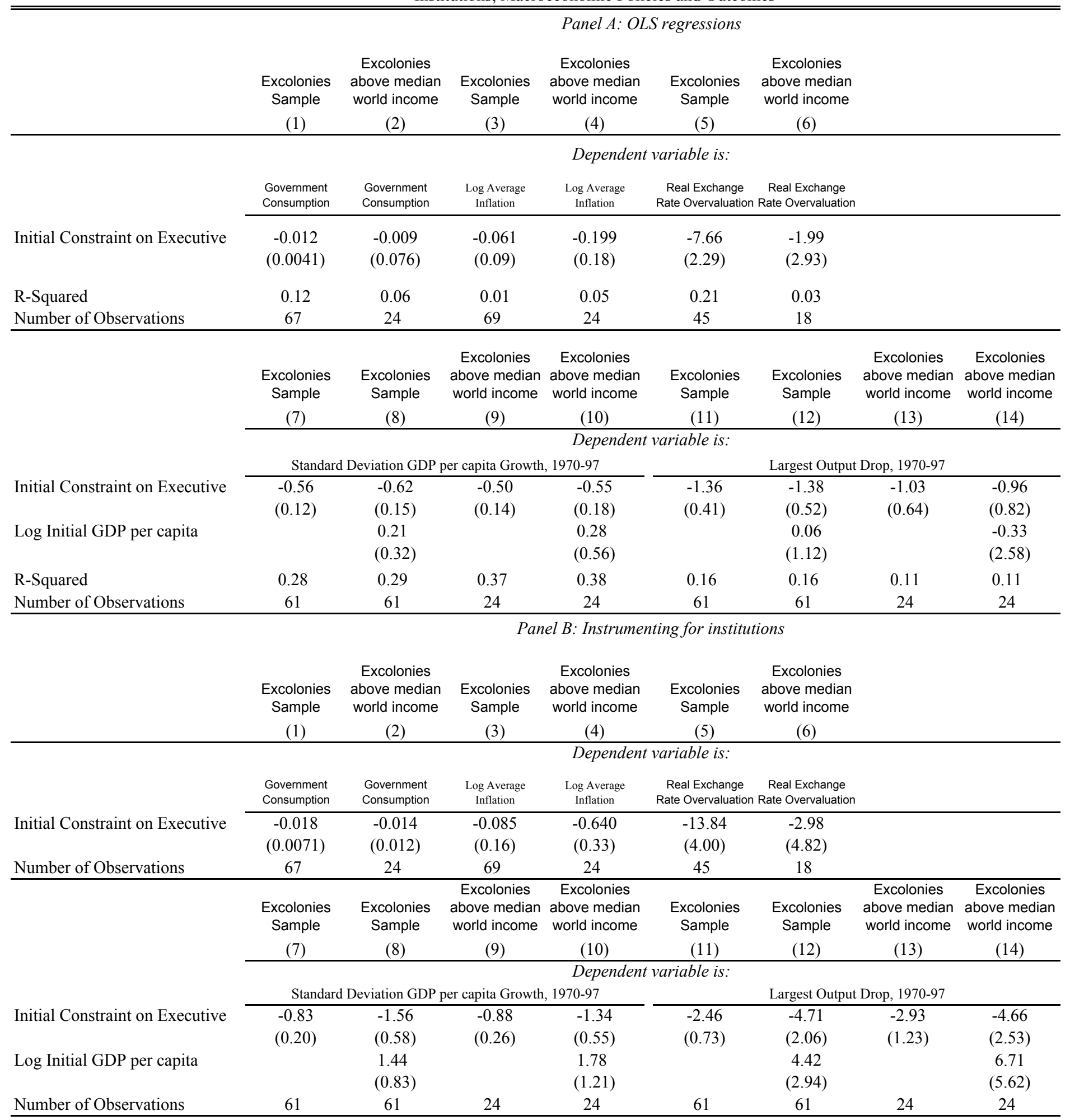

Standard errors are in parentheses. All regressions are cross-sectional regressions with one observation per country. In the first part of each panel the dependent variables are measures of macroeconomic policy. Log average inflation is the log of average annual inflation in the Consumer Price Index from 1970 to 1997, from the World Bank. Government Consumption is the average of the ratio of real government "consumption" expenditure to real GDP from 1970 to 1989, from Barro and Lee (1993). Real Exchange Rate Overvaluation is an index of real overvaluation of the official exchange rate during 1960-98, constructed by Easterly and Levine (2002) using the methodology of Dollar (1992). In the second part of both panels, the dependent variables are the standard deviation of the average annual growth rate of GDP from 1970 to 1997, and the lowest annual growth rate of GDP per capita from 1970 to 1997 (with the sign changed so that an output fall is a positive number); both are from the World Bank.

"Initial Constraint on the Executive" is average constraint on executive in 1950, 1960 and 1970, which is an average of the Polity score in each year; countries that are still colonies in a particular year are assigned a score of 1 . In both panels we instrument for institutions using log settler mortality (where mortality is per 1000 with replacement). The Excolonies Sample includes all former colonies of European Powers for which Acemoglu, Johnson and Robinson (2001) report data. The alternative sample is excolonies above median world per capita income in 1970, using the SummersHeston estimates from Barro and Lee (1993), and without Gabon. For more detailed data definitions and sources see Appendix Table 1. 
Table 3

Volatility and Government Consumption

Dependent Variable is standard deviation of Growth Rate of real GDP per capita between 1970 and 1997

\begin{tabular}{|c|c|c|c|c|c|c|c|c|c|}
\hline & $\begin{array}{l}\text { Whole World } \\
\text { (1) }\end{array}$ & $\begin{array}{c}\text { Excolonies } \\
\text { Sample } \\
(2) \\
\end{array}$ & $\begin{array}{c}\text { Excolonies } \\
\text { above median } \\
\text { world income } \\
\text { (3) }\end{array}$ & $\begin{array}{c}\text { Excolonies } \\
\text { Sample } \\
(4)\end{array}$ & $\begin{array}{c}\text { Excolonies } \\
\text { above median } \\
\text { world income } \\
(5) \\
\end{array}$ & $\begin{array}{c}\text { Excolonies } \\
\text { Sample } \\
(6) \\
\end{array}$ & $\begin{array}{c}\text { Excolonies } \\
\text { above median } \\
\text { world income } \\
(7)\end{array}$ & $\begin{array}{c}\text { Excolonies } \\
\text { Sample } \\
(8) \\
\end{array}$ & $\begin{array}{l}\text { Excolonies } \\
\text { above } \\
\text { median world } \\
\text { income } \\
\text { (9) }\end{array}$ \\
\hline & \multicolumn{3}{|c|}{ Just macro variables } & \multicolumn{2}{|c|}{$\begin{array}{c}\text { Macro and Institutions; not } \\
\text { instrumenting for institutions }\end{array}$} & \multicolumn{2}{|c|}{$\begin{array}{l}\text { Macro and Institutions; } \\
\text { instrumenting for institutions }\end{array}$} & \multicolumn{2}{|c|}{$\begin{array}{l}\text { Macro and Institutions; } \\
\text { instrumenting for both }\end{array}$} \\
\hline & & Panel & 1: 1970-1997, v & ithout contro & Iling for initial & come & & & \\
\hline Government Consumption & $\begin{array}{c}8.09 \\
(2.83)\end{array}$ & $\begin{array}{c}8.09 \\
(3.81)\end{array}$ & $\begin{array}{c}4.90 \\
(6.89)\end{array}$ & $\begin{array}{c}3.30 \\
(3.54)\end{array}$ & $\begin{array}{c}4.18 \\
(3.92)\end{array}$ & $\begin{array}{c}0.63 \\
(4.11)\end{array}$ & $\begin{array}{c}1.52 \\
(4.84)\end{array}$ & $\begin{array}{l}-5.13 \\
(5.19)\end{array}$ & $\begin{array}{l}-3.81 \\
(6.23)\end{array}$ \\
\hline Initial Constraint on the Executive & & & & $\begin{array}{l}-0.52 \\
(0.12)\end{array}$ & $\begin{array}{l}-0.46 \\
(0.14)\end{array}$ & $\begin{array}{l}-0.82 \\
(0.23)\end{array}$ & $\begin{array}{l}-0.86 \\
(0.28)\end{array}$ & $\begin{array}{l}-0.92 \\
(0.25)\end{array}$ & $\begin{array}{l}-0.94 \\
(0.32)\end{array}$ \\
\hline R-Squared & 0.08 & 0.07 & 0.02 & 0.29 & 0.40 & & & & \\
\hline Number of Observations & 96 & 61 & 25 & 61 & 24 & 61 & 24 & 60 & 24 \\
\hline \multicolumn{10}{|c|}{ Panel B: 1970-1997, controlling for initial income } \\
\hline Government Consumption & $\begin{array}{c}2.89 \\
(2.94)\end{array}$ & $\begin{array}{c}5.57 \\
(4.25)\end{array}$ & $\begin{array}{c}1.48 \\
(7.31)\end{array}$ & $\begin{array}{c}4.70 \\
(3.77)\end{array}$ & $\begin{array}{c}5.30 \\
(4.15)\end{array}$ & $\begin{array}{c}3.35 \\
(5.01)\end{array}$ & $\begin{array}{c}5.03 \\
(5.81)\end{array}$ & $\begin{array}{l}-1.29 \\
(6.48)\end{array}$ & $\begin{array}{l}-1.92 \\
(7.28)\end{array}$ \\
\hline Log Initial GDP per capita & $\begin{array}{l}-0.82 \\
(0.21)\end{array}$ & $\begin{array}{l}-0.41 \\
(0.32)\end{array}$ & $\begin{array}{l}-1.06 \\
(0.84)\end{array}$ & $\begin{array}{c}0.36 \\
(0.34)\end{array}$ & $\begin{array}{c}0.51 \\
(0.58)\end{array}$ & $\begin{array}{c}1.56 \\
(0.83)\end{array}$ & $\begin{array}{c}1.95 \\
(1.22)\end{array}$ & $\begin{array}{l}1.46 \\
(0.87)\end{array}$ & $\begin{array}{c}1.72 \\
(1.26)\end{array}$ \\
\hline Initial Constraint on the Executive & & & & $\begin{array}{l}-0.61 \\
(0.15)\end{array}$ & $\begin{array}{l}-0.55 \\
(0.18)\end{array}$ & $\begin{array}{l}-1.56 \\
(0.83)\end{array}$ & $\begin{array}{l}-1.31 \\
(0.54)\end{array}$ & $\begin{array}{l}-1.59 \\
(0.59)\end{array}$ & $\begin{array}{l}-1.35 \\
(0.58)\end{array}$ \\
\hline R-Squared & 0.21 & 0.10 & 0.08 & & & & & & \\
\hline Number of Observations & 96 & 61 & 25 & 61 & 24 & 61 & 24 & 60 & 24 \\
\hline \multicolumn{10}{|c|}{ Panel C: 5-year panels, 1970-1997, without controlling for initial income } \\
\hline Government Consumption & $\begin{array}{c}4.53 \\
(2.31)\end{array}$ & $\begin{array}{c}5.27 \\
(3.48)\end{array}$ & $\begin{array}{c}1.39 \\
(2.76)\end{array}$ & $\begin{array}{c}2.22 \\
(3.82)\end{array}$ & $\begin{array}{c}0.13 \\
(3.24)\end{array}$ & $\begin{array}{l}-1.82 \\
(4.19)\end{array}$ & $\begin{array}{l}-1.78 \\
(4.71)\end{array}$ & & \\
\hline Initial Constraint on the Executive & & & & $\begin{array}{l}-0.39 \\
(0.14)\end{array}$ & $\begin{array}{l}-0.23 \\
(0.12)\end{array}$ & $\begin{array}{l}-0.91 \\
(0.27)\end{array}$ & $\begin{array}{l}-0.57 \\
(0.32)\end{array}$ & & \\
\hline R-Squared & 0.03 & 0.02 & 0.02 & 0.08 & 0.06 & & & & \\
\hline Number of Countries & 95 & 61 & 24 & 61 & 24 & 61 & 24 & & \\
\hline \multicolumn{10}{|c|}{ Panel D: 5-year panels, 1970-1997, controlling for initial income } \\
\hline Government Consumption & $\begin{array}{l}-2.07 \\
(2.61)\end{array}$ & $\begin{array}{l}-2.58 \\
(3.49)\end{array}$ & $\begin{array}{l}-2.87 \\
(5.29)\end{array}$ & $\begin{array}{c}2.04 \\
(3.48)\end{array}$ & $\begin{array}{c}-2.76 \\
(5.48)\end{array}$ & $\begin{array}{c}0.74 \\
(4.41)\end{array}$ & $\begin{array}{l}-1.86 \\
(6.20)\end{array}$ & & \\
\hline Lagged Log GNP per capita & $\begin{array}{l}-0.68 \\
(0.13)\end{array}$ & $\begin{array}{l}-0.35 \\
(0.23)\end{array}$ & $\begin{array}{l}-0.73 \\
(0.45)\end{array}$ & $\begin{array}{l}-0.04 \\
(0.33)\end{array}$ & $\begin{array}{l}-0.65 \\
(0.58)\end{array}$ & $\begin{array}{c}0.71 \\
(0.58)\end{array}$ & $\begin{array}{l}-0.03 \\
(0.79)\end{array}$ & & \\
\hline Initial Constraint on the Executive & & & & $\begin{array}{l}-0.40 \\
(0.20)\end{array}$ & $\begin{array}{l}-0.06 \\
(0.15)\end{array}$ & $\begin{array}{l}-1.35 \\
(0.56)\end{array}$ & $\begin{array}{l}-0.56 \\
(0.48)\end{array}$ & & \\
\hline R-Squared & 0.13 & 0.10 & 0.09 & 0.08 & 0.09 & & & & \\
\hline Number of Countries & 94 & 60 & 24 & 60 & 24 & 60 & 24 & & \\
\hline
\end{tabular}

Standard errors are in parentheses. Panels A and B are cross-sectional regressions with one observation per country; Panels C and D are "5-year" unbalanced panels (1970-75, 1976-80, 1981-85, 1986-90, 1991-95, 1996-1997) with up to 6 observations per country. Panels C and D include time dummies but not country dummies we cluster the errors by country. In all Panels the dependent variable is standard deviation of GDP per capita growth rate over either the whole period (Panels A and B) or the relevant "5-year" subperiod (Panels C and D). Government Consumption is the average of the ratio of real government "consumption" expenditure to real GDP from 1970 to 1989, from Barro and Lee (1993). For Panels A and B, in columns 8 and 9, government consumption is instrumented using its lagged value (i.e, government consumption 1960-69 for government consumption 1970-89). In Panel B log initial GDP per capita is the Summers-Heston estimate for 1970, from Barro and Lee (1993). In Panel D lagged log GNP per capita is at the start of each "5-year" period (1970 for 1970-75, etc); using GNP rather than GDP increases our sample size.

"Initial Constraint on the Executive" is average constraint on executive in 1950, 1960 and 1970, which is an average of the Polity score in each year; countries that are still colonies in a particular year are assigned a score of 1 . In all panels we instrument for institutions using log settler mortality (where mortality is per 1000 with replacement). Whole World is the set of countries for which we have data on the outcome and the macroeconomic variable. The Excolonies Sample includes all former colonies of European Powers for which Acemoglu, Johnson and Robinson (2001) report data. The alternative sample is excolonies above median world income (and without Gabon) in 1970, using the Summers-Heston estimates from Barro and Lee (1993). For more detailed data definitions and sources see Appendix Table 1. 
Table 4

Volatility and Inflation

\begin{tabular}{|c|c|c|c|c|c|c|c|c|c|}
\hline & \multicolumn{9}{|c|}{ Dependent Variable is standard deviation of Growth Rate of real GDP per capita, 1970-1997 } \\
\hline & $\begin{array}{l}\text { Whole World } \\
\text { (1) }\end{array}$ & $\begin{array}{c}\text { Excolonies } \\
\text { Sample } \\
(2)\end{array}$ & $\begin{array}{c}\text { Excolonies } \\
\text { above median } \\
\text { world income } \\
\text { (3) }\end{array}$ & $\begin{array}{c}\text { Excolonies } \\
\text { Sample } \\
(4)\end{array}$ & $\begin{array}{c}\text { Excolonies } \\
\text { above median } \\
\text { world income } \\
(5)\end{array}$ & $\begin{array}{c}\text { Excolonies } \\
\text { Sample } \\
(6)\end{array}$ & $\begin{array}{c}\text { Excolonies } \\
\text { above median } \\
\text { world income } \\
(7)\end{array}$ & $\begin{array}{c}\text { Excolonies } \\
\text { Sample } \\
(8)\end{array}$ & $\begin{array}{c}\text { Excolonies } \\
\text { above } \\
\text { median world } \\
\text { income } \\
(9)\end{array}$ \\
\hline & \multicolumn{3}{|c|}{ Just macro variables } & \multicolumn{2}{|c|}{$\begin{array}{l}\text { Macro and Institutions; not } \\
\text { instrumenting for institutions }\end{array}$} & \multicolumn{2}{|c|}{$\begin{array}{c}\text { Macro and Institutions; } \\
\text { instrumenting for institutions }\end{array}$} & \multicolumn{2}{|c|}{$\begin{array}{l}\text { Macro and Institutions; } \\
\text { instrumenting for both }\end{array}$} \\
\hline & \multicolumn{9}{|c|}{ Panel A: 1970-1997, without controlling for initial income } \\
\hline \multirow[t]{2}{*}{ Log Average Inflation } & 0.30 & 0.12 & 0.51 & 0.11 & 0.41 & 0.10 & 0.34 & -0.14 & 0.42 \\
\hline & $(0.17)$ & $(0.19)$ & $(0.17)$ & $(0.16)$ & $(0.14)$ & $(0.17)$ & $(0.16)$ & $(0.42)$ & $(0.35)$ \\
\hline \multirow[t]{2}{*}{ Initial Constraint on the Executive } & & & & -0.56 & -0.42 & -0.83 & -0.66 & -0.86 & -0.62 \\
\hline & & & & $(0.12)$ & $(0.12)$ & $(0.21)$ & $(0.23)$ & $(0.22)$ & $(0.34)$ \\
\hline R-Squared & 0.03 & 0.01 & 0.30 & 0.29 & 0.55 & & & & \\
\hline & \multicolumn{9}{|c|}{ Panel B: 1970-1997, controlling for initial income } \\
\hline \multirow[t]{2}{*}{ Log Average Inflation } & 0.21 & 0.17 & 0.48 & 0.09 & 0.41 & -0.04 & 0.33 & -0.07 & 0.25 \\
\hline & $(0.16)$ & $(0.19)$ & $(0.17)$ & $(0.17)$ & $(0.14)$ & $(0.23)$ & $(0.19)$ & $(0.48)$ & $(0.48)$ \\
\hline \multirow[t]{2}{*}{ Log Initial GDP per capita } & -0.88 & -0.63 & -0.55 & 0.19 & 0.33 & 1.47 & 1.29 & 1.25 & 1.35 \\
\hline & $(0.19)$ & $(0.29)$ & $(0.46)$ & $(0.32)$ & $(0.48)$ & $(0.88)$ & $(0.96)$ & $(0.74)$ & $(1.01)$ \\
\hline \multirow[t]{2}{*}{ Initial Constraint on the Executive } & & & & -0.62 & -0.48 & -1.57 & -1.00 & -1.45 & -1.06 \\
\hline & & & & $(0.15)$ & $(0.16)$ & $(0.61)$ & $(0.45)$ & $(0.51)$ & $(0.63)$ \\
\hline R-Squared & 0.22 & 0.08 & 0.35 & 0.29 & 0.56 & & & & \\
\hline \multirow[t]{2}{*}{ Number of Observations } & 96 & 61 & 24 & 61 & 24 & 61 & 24 & 48 & 19 \\
\hline & \multicolumn{9}{|c|}{ Panel C: 5-year panels, 1970-1997, without controlling for initial income } \\
\hline \multirow[t]{2}{*}{ Log Average Inflation } & 0.33 & 0.16 & 0.33 & 0.13 & 0.27 & 0.11 & 0.22 & & \\
\hline & $(0.10)$ & $(0.12)$ & $(0.16)$ & $(0.12)$ & $(0.15)$ & $(0.12)$ & $(0.16)$ & & \\
\hline \multirow[t]{2}{*}{ Initial Constraint on the Executive } & & & & -0.40 & -0.27 & -0.64 & -0.47 & & \\
\hline & & & & $(0.09)$ & $(0.07)$ & $(0.15)$ & $(0.16)$ & & \\
\hline \multirow[t]{2}{*}{ Number of Countries } & 96 & 61 & 24 & 61 & 24 & 61 & 24 & & \\
\hline & \multicolumn{9}{|c|}{ Panel D: 5-year panels, 1970-1997, controlling for initial income } \\
\hline \multirow[t]{2}{*}{ Log Average Inflation } & 0.16 & 0.17 & 0.28 & 0.057 & 0.27 & 0.19 & 0.25 & & \\
\hline & $(0.11)$ & $(0.12)$ & $(0.18)$ & $(0.20)$ & $(0.17)$ & $(0.13)$ & $(0.17)$ & & \\
\hline \multirow[t]{2}{*}{ Lagged Log GNP per capita } & -0.48 & -0.30 & -0.28 & 0.18 & -0.01 & 0.54 & 0.52 & & \\
\hline & $(0.09)$ & $(0.16)$ & $(0.20)$ & $(0.11)$ & $(0.19)$ & $(0.40)$ & $(0.45)$ & & \\
\hline \multirow[t]{2}{*}{ Initial Constraint on the Executive } & & & & -0.43 & -0.26 & -1.04 & -0.78 & & \\
\hline & & & & $(0.13)$ & $(0.072)$ & $(0.40)$ & $(0.37)$ & & \\
\hline R-Squared & 0.17 & 0.14 & 0.20 & 0.19 & 0.23 & & & & \\
\hline Number of Countries & 96 & 61 & 24 & 61 & 24 & 61 & 24 & & \\
\hline
\end{tabular}

Standard errors are in parentheses. Panels A and B are cross-sectional regressions with one observation per country; Panels C and D are "5-year" unbalanced panels (1970-75, 1976-80, 1981-85, 1986-90, 1991-95, 1996-1997) with up to 6 observations per country. Panels C and D include time dummies but not country dummies; we cluster the errors by country. In all Panels the dependent variable is standard deviation of GDP per capita growth rate over either the whole period (Panels A and B) or the relevant "5-year" subperiod (Panels C and D). In Panels A and B log average inflation is the log of average annual inflation in the Consumer Price Index from 1970 to 1997, from the World Bank; in Panels B and C we use the "5-year" subperiod values of the same variable. In Panels A and B, columns 8 and 9, log average inflation is instrumented using its lagged value (i.e., log average inflation over 1960-69). In Panel B log initial GDP per capita is the Summers-Heston estimate for 1970, from Barro and Lee (1993). In Panel D lagged log GNP per capita is at the start of each "5-year" period (1970 for 1970-75, etc); using GNP rather than GDP increases our sample size.

"Initial Constraint on the Executive" is average constraint on executive in 1950, 1960 and 1970, which is an average of the Polity score in each year; countries that are still colonies in a particular year are assigned a score of 1 . In all panels we instrument for institutions using log settler mortality (where mortality is per 1000 with replacement). Whole World is the set of countries for which we have data on the outcome and the macroeconomic variable. The Excolonies Sample includes all former colonies of European Powers for which Acemoglu, Johnson and Robinson (2001) report data. The alternative sample is excolonies above median world per capita income in 1970, using the Summers-Heston estimates from Barro and Lee (1993), and without Gabon. For more detailed data definitions and sources see Appendix Table 1. 
Table 5

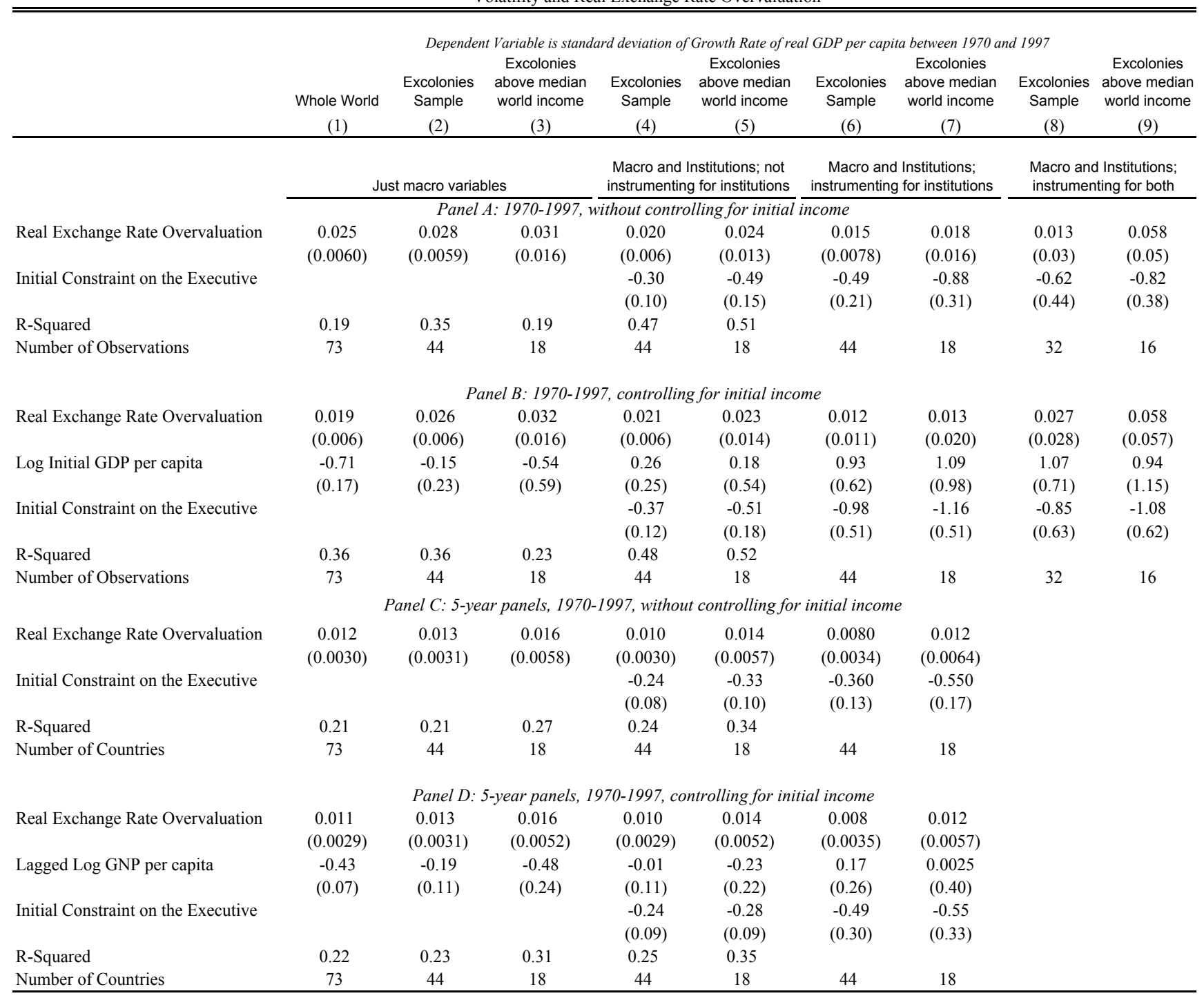

Standard errors are in parentheses. Panels A and B are cross-sectional regressions with one observation per country. Panels C and D are "5-year" unbalanced panels (1970-75, 1976-80, 1981-85, 1986-90, 1991-95, 1996-1997) with up to 6 observations per country. Panels C and D include time dummies but not country dummies; we cluster the errors by country. In all Panels the dependent variable is standard deviation of GDP per capita growth rate over either the whole period (Panels A and B) or the relevant "5-year" subperiod (Panels C and D). In Panels A and B, Real Exchange Rate Overvaluation is an index of real overvaluation of the official exchange rate, 1970-98, constructed by Easterly and Levine (2002) applying the methodology of Dollar (1992); in Panels C and D we use the "5-year" period values of the same variable. In columns 8 and 9 of Panels A and B we instrument overvaluation 1970-98 using its lagged value 1960-69. In Panel B log initial GDP per capita is the Summers-Heston estimate for 1970, from Barro and Lee (1993). In Panel D lagged log GNP per capita is at the start of each "5-year" period (1970 for 1970-75, etc); using GNP rather than GDP increases our sample size.

"Initial Constraint on the Executive" is average constraint on executive in 1950, 1960 and 1970, which is an average of the Polity score in each year; countries that are still colonies in a particular year are assigned a score of 1 . In all panels we instrument for institutions using log settler mortality (where mortality is per 1000 with replacement). Whole World is the set of countries for which we have data on the outcome and the macroeconomic variable. The Excolonies Sample includes all former colonies of European Powers for which Acemoglu, Johnson and Robinson (2001) report data. The alternative sample is excolonies above median world income in 1970, using the Summers-Heston estimates from Barro and Lee (1993), and without Gabon. For more detailed data definitions and sources see Appendix Table 1. 
Table 6

Worst Output Performance and the Three Macroeconomic Variables

Dependent Variable is largest annual drop in real GDP per capita between 1970 and 1997

\begin{tabular}{|c|c|c|c|c|c|c|c|}
\hline $\begin{array}{l}\text { Excolonies } \\
\text { Sample }\end{array}$ & $\begin{array}{l}\text { Excolonies } \\
\text { above median } \\
\text { world income }\end{array}$ & $\begin{array}{c}\text { Excolonies } \\
\text { Sample }\end{array}$ & $\begin{array}{l}\text { Excolonies } \\
\text { above median } \\
\text { world income }\end{array}$ & $\begin{array}{c}\text { Excolonies } \\
\text { Sample }\end{array}$ & $\begin{array}{l}\text { Excolonies } \\
\text { above } \\
\text { median world } \\
\text { income }\end{array}$ & $\begin{array}{c}\text { Excolonies } \\
\text { Sample }\end{array}$ & $\begin{array}{l}\text { Excolonies } \\
\text { above median } \\
\text { world income }\end{array}$ \\
\hline (1) & (2) & (3) & (4) & (5) & (6) & $(7)$ & (8) \\
\hline
\end{tabular}

Cross-section, 1970-1997, without controlling for initial

income

Cross-section, 1970-1997, controlling for initial income

\begin{tabular}{|c|c|c|c|c|c|c|c|}
\hline \multicolumn{2}{|c|}{$\begin{array}{l}\text { Macro and Institutions; } \\
\text { instrumenting for institutions }\end{array}$} & \multicolumn{2}{|c|}{$\begin{array}{l}\text { Macro and Institutions; } \\
\text { instrumenting for both }\end{array}$} & \multicolumn{2}{|c|}{$\begin{array}{c}\text { Macro and Institutions; } \\
\text { instrumenting for institutions }\end{array}$} & \multicolumn{2}{|c|}{$\begin{array}{l}\text { Macro and Institutions; } \\
\text { instrumenting for both }\end{array}$} \\
\hline \multicolumn{8}{|c|}{ Panel A: Macroeconomic Variable is Government Consumption } \\
\hline 2.29 & 8.75 & -16.60 & -23.99 & 10.67 & 22.17 & -6.04 & -17.26 \\
\hline \multirow[t]{3}{*}{$(14.67)$} & $(22.54)$ & $(18.51)$ & $(30.13)$ & $(17.74)$ & $(27.06)$ & $(22.30)$ & $(34.60)$ \\
\hline & & & & 4.78 & 7.46 & 4.00 & 6.12 \\
\hline & & & & $(2.93)$ & $(5.67)$ & $(2.99)$ & $(5.96)$ \\
\hline-2.42 & -2.81 & -2.74 & -3.27 & -4.71 & -4.54 & -4.58 & -4.76 \\
\hline$(0.83)$ & $(1.32)$ & $(0.88)$ & $(1.54)$ & $(2.08)$ & $(2.51)$ & $(2.03)$ & $(2.75)$ \\
\hline 61 & 24 & 60 & 24 & 61 & 24 & 60 & 24 \\
\hline
\end{tabular}

Number of Observations

Panel B: Macroeconomic Variable is Log Average Inflation

Log Average Inflation

$0.75 \quad 1.35$

(0.60) (0.78)
$-0.78$

(1.37)

Log Initial GDP per capita

Initial Constraint on the Executive

Number of Observations

$\begin{array}{cc}-2.45 & -2.07 \\ (0.73) & (1.11) \\ 61 & 24\end{array}$

-2.71
$(0.70)$
49

-0.45
$(1.38)$

(1.38)

(0.80)

4.21

(3.06)

\section{$-2.34$}

$-4.59$

(1.34)

(2.12)

20

61

Panel C: Macroeconomic Variable is Overvaluation of Real Exchange Rate

Real Exchange Rate Overvaluation

0.0056

(0.032)

0.056
$(0.06)$

0.028

(0.10)

0.22
$(0.18)$

$-0.011$

(0.053)

5.04

(3.11)

$-1.98$

$-2.68$

(0.86)

(1.16)

(1.59)

$-2.51$

(1.32)

$-4.86$

(2.56)

16

44

32

1.31

(0.92)

4.78

(4.69)

$-3.32$

(2.20)

24
$-0.62$

(1.70)

4.30

(2.61)

$-4.84$

(1.80)

48

0.036
$(0.077)$
3.87
$(3.77)$
-3.68
$(1.96)$

0.22

(0.21)

3.46

(4.13)

$-3.47$

(2.23)

16

Standard errors are in parentheses. All Panels are cross-sectional regressions with one observation per country. In all Panels the dependent variable is the lowest annual growth rate of GDP per capita from 1970 to 1997 (with the sign changed so that an output fall is a positive number), from the World Bank. Log average inflation (in Panel A) is the log of average annual inflation in the Consumer Price Index from 1970 to 1997 , from the World Bank. In columns 3, 4, 7 and 8, log average inflation is instrumented using its lagged value (i.e., log average inflation over 1960-69).

Government Consumption (Panel B) is the average of the ratio of real government "consumption" expenditure to real GDP from 1970 to 1989 , from Barro-Lee. In columns 3, 4, 7, and 8, government consumption is instrumented using its lagged value (i.e., government consumption 1960-69 for government consumption 1970-89). Real Exchange Rate Overvaluation (Panel C) is an index of real overvaluation of the official exchange rate during 1960-98, constructed by Easterly and Levine (2002) using the methodology of Dollar (1992). In columns 3, 4, 7, and 8, the real exchange rate overvaluation measure is instrumented using its lagged value (i.e., real overvaluation 1960-69 for real overvaluation 1970-98). Log initial GDP per capita is the Summers Heston estimate for 1970, from Barro and Lee (1993).

"Initial Constraint on the Executive" is average constraint on executive in 1950, 1960 and 1970, which is an average of the Polity score in each year; countries that are still colonies in a particular year are assigned a score of 1 . In all panels we instrument for institutions using log settler mortality (where mortality is per 1000 with replacement). The Excolonies Sample includes all former colonies of European Powers for which Acemoglu, Johnson and Robinson (2001) report data. The alternative sample is excolonies above median world income in 1970, using the Summers-Heston estimates from Barro and Lee (1993), and without Gabon. For more detailed data definitions and sources see Appendix Table 1. 
Table 7

Growth and the Three Macroeconomic Variables

\begin{tabular}{|c|c|c|c|c|c|c|c|c|}
\hline & \multicolumn{8}{|c|}{ Dependent Variable is Average Annual Growth Rate of Real GDP per capita, 1970-97 } \\
\hline & $\begin{array}{c}\text { Excolonies } \\
\text { Sample } \\
(1) \\
\end{array}$ & $\begin{array}{c}\text { Excolonies } \\
\text { above median } \\
\text { world income } \\
(2)\end{array}$ & $\begin{array}{c}\text { Excolonies } \\
\text { Sample } \\
(3) \\
\end{array}$ & $\begin{array}{l}\text { Excolonies above } \\
\text { median world } \\
\text { income } \\
(4) \\
\end{array}$ & $\begin{array}{c}\text { Excolonies } \\
\text { Sample } \\
(5)\end{array}$ & $\begin{array}{c}\text { Excolonies } \\
\text { above median } \\
\text { world income } \\
(6)\end{array}$ & $\begin{array}{c}\text { Excolonies } \\
\text { Sample } \\
(7)\end{array}$ & $\begin{array}{c}\text { Excolonies } \\
\text { above median } \\
\text { world income } \\
(8)\end{array}$ \\
\hline & \multicolumn{4}{|c|}{$\begin{array}{l}\text { Cross-section, 1970-1997, without controlling for initial } \\
\text { income }\end{array}$} & \multicolumn{4}{|c|}{ Cross-section, 1970-1997, controlling for initial income } \\
\hline & \multicolumn{2}{|c|}{$\begin{array}{c}\text { Macro and Institutions; } \\
\text { instrumenting for institutions }\end{array}$} & \multicolumn{2}{|c|}{$\begin{array}{l}\text { Macro and Institutions; } \\
\text { instrumenting for both }\end{array}$} & \multicolumn{2}{|c|}{$\begin{array}{c}\text { Macro and Institutions; } \\
\text { instrumenting for institutions }\end{array}$} & \multicolumn{2}{|c|}{$\begin{array}{l}\text { Macro and Institutions; } \\
\text { instrumenting for both }\end{array}$} \\
\hline & \multicolumn{8}{|c|}{ Panel A: Macroeconomic Variable is Government Consumption } \\
\hline Government Consumption & $\begin{array}{l}-0.23 \\
(4.58)\end{array}$ & $\begin{array}{l}-2.11 \\
(7.03)\end{array}$ & $\begin{array}{l}0.038 \\
(5.51)\end{array}$ & $\begin{array}{c}3.64 \\
(8.86)\end{array}$ & $\begin{array}{l}-3.19 \\
(6.07)\end{array}$ & $\begin{array}{l}-6.90 \\
(8.57)\end{array}$ & $\begin{array}{l}-4.31 \\
(7.55)\end{array}$ & $\begin{array}{c}1.00 \\
(10.56)\end{array}$ \\
\hline Log Initial GDP per capita & & & & & $\begin{array}{l}-1.68 \\
(1.00)\end{array}$ & $\begin{array}{l}-2.67 \\
(1.80)\end{array}$ & $\begin{array}{l}-1.65 \\
(1.01)\end{array}$ & $\begin{array}{l}-2.40 \\
(1.82)\end{array}$ \\
\hline Initial Constraint on the Executive & $\begin{array}{l}0.76 \\
(0.26)\end{array}$ & $\begin{array}{l}0.58 \\
(0.41)\end{array}$ & $\begin{array}{l}0.76 \\
(0.26)\end{array}$ & $\begin{array}{l}0.66 \\
(0.45)\end{array}$ & $\begin{array}{c}1.57 \\
(0.71)\end{array}$ & $\begin{array}{c}1.20 \\
(0.80)\end{array}$ & $\begin{array}{c}1.53 \\
(0.69)\end{array}$ & $\begin{array}{c}1.24 \\
(0.84)\end{array}$ \\
\hline Number of Observations & 61 & 24 & 60 & 24 & 61 & 24 & 60 & 24 \\
\hline & \multicolumn{8}{|c|}{ Panel B: Macroeconomic Variable is Log Average Inflation } \\
\hline Log Average Inflation & $\begin{array}{l}-0.36 \\
(0.18)\end{array}$ & $\begin{array}{l}-0.34 \\
(0.23)\end{array}$ & $\begin{array}{c}0.21 \\
(0.47)\end{array}$ & $\begin{array}{l}-0.09 \\
(0.56)\end{array}$ & $\begin{array}{l}-0.23 \\
(0.27)\end{array}$ & $\begin{array}{l}-0.30 \\
(0.31)\end{array}$ & $\begin{array}{c}0.15 \\
(0.57)\end{array}$ & $\begin{array}{c}0.20 \\
(0.86)\end{array}$ \\
\hline Log Initial GDP per capita & & & & & $\begin{array}{l}-1.45 \\
(1.02)\end{array}$ & $\begin{array}{l}-1.99 \\
(1.59)\end{array}$ & $\begin{array}{l}-1.24 \\
(0.87)\end{array}$ & $\begin{array}{l}-2.18 \\
(1.83)\end{array}$ \\
\hline Initial Constraint on the Executive & $\begin{array}{l}0.76 \\
(0.22)\end{array}$ & $\begin{array}{l}0.34 \\
(0.29)\end{array}$ & $\begin{array}{l}0.73 \\
(0.24)\end{array}$ & $\begin{array}{l}0.46 \\
(0.54)\end{array}$ & $\begin{array}{l}1.50 \\
(0.71)\end{array}$ & $\begin{array}{c}0.93 \\
(0.75)\end{array}$ & $\begin{array}{c}1.32 \\
(0.60)\end{array}$ & $\begin{array}{l}1.17 \\
(1.14)\end{array}$ \\
\hline Number of Observations & 61 & 25 & 49 & 49 & 61 & 24 & 48 & 19 \\
\hline & \multicolumn{8}{|c|}{ Panel C: Macroeconomic Variable is Overvaluaton of Real Exchange Rate } \\
\hline Real Exchange Rate Overvaluation & $\begin{array}{l}-0.049 \\
(0.012)\end{array}$ & $\begin{array}{l}-0.018 \\
(0.025)\end{array}$ & $\begin{array}{l}0.013 \\
(0.041)\end{array}$ & $\begin{array}{l}0.0072 \\
(0.082)\end{array}$ & $\begin{array}{l}0.0010 \\
(0.020)\end{array}$ & $\begin{array}{l}-0.007 \\
(0.033)\end{array}$ & $\begin{array}{r}-0.0052 \\
(0.038)\end{array}$ & $\begin{array}{l}0.0094 \\
(0.105)\end{array}$ \\
\hline Log Initial GDP per capita & & & & & $\begin{array}{l}-1.79 \\
(1.17)\end{array}$ & $\begin{array}{l}-2.09 \\
(1.62)\end{array}$ & $\begin{array}{l}-1.38 \\
(0.96)\end{array}$ & $\begin{array}{l}-2.49 \\
(2.10)\end{array}$ \\
\hline Initial Constraint on the Executive & $\begin{array}{c}0.64 \\
(0.33)\end{array}$ & $\begin{array}{c}0.46 \\
(0.49)\end{array}$ & $\begin{array}{c}0.66 \\
(0.66)\end{array}$ & $\begin{array}{c}0.56 \\
(0.61)\end{array}$ & $\begin{array}{c}1.60 \\
(0.96)\end{array}$ & $\begin{array}{c}1.00 \\
(0.84)\end{array}$ & $\begin{array}{c}0.96 \\
(0.85)\end{array}$ & $\begin{array}{c}1.25 \\
(1.13)\end{array}$ \\
\hline Number of Observations & 44 & 18 & 32 & 16 & 44 & 18 & 32 & 16 \\
\hline
\end{tabular}

Standard errors are in parentheses. All Panels are cross-sectional regressions with one observation per country. In all Panels the dependent variable is the average annual GDP per capita growth rate over 1970-97. Log average inflation (in Panel A) is the log of average annual inflation in the Consumer Price Index from 1970 to 1997, from the World Bank. In columns 3, 4, 7 and 8, log average inflation is instrumented using its lagged value (i.e., log average inflation over 1960-69).

Government Consumption (Panel B) is the average of the ratio of real government "consumption" expenditure to real GDP from 1970 to 1989 , from Barro-Lee. In columns 3, 4, 7, and 8, government consumption is instrumented using its lagged value (i.e., government consumption 1960-69 for government consumption 197089). Real Exchange Rate Overvaluation (Panel C) is an index of real overvaluation of the official exchange rate during 1960-97, constructed by Easterly and Levine (2002) using the methodology of Dollar (1992). In columns 3, 4, 7, and 8, real overvaluation is instrumented using its lagged value (i.e., real overvaluation 1960-69 for real overvaluation 1970-98). Log initial GDP per capita is the Summers Heston estimate for 1970, from Barro-Lee.

"Initial Constraint on the Executive" is average constraint on executive in 1950, 1960 and 1970, which is an average of the Polity score in each year; countries that are still colonies in a particular year are assigned a score of 1 . In all regressions we instrument for institutions using log settler mortality (where mortality is per 1000 with replacement). The Excolonies Sample includes all former colonies of European Powers for which Acemoglu, Johnson and Robinson (2001) report data. The alternative sample is excolonies above median world income in 1970, using the Summers-Heston estimates from Barro and Lee (1993), and without Gabon. For more detailed data definitions and sources see Appendix Table 1. 
Table 8

Institutions and Volatility: Other Controls

Dependent Variable is standard deviation of Growth Rate of real GDP per capita

\begin{tabular}{|c|c|c|c|c|c|c|c|c|c|c|}
\hline & $\begin{array}{c}\text { All macro } \\
\text { variables } \\
(1)\end{array}$ & $\begin{array}{c}\text { All macro } \\
\text { variables } \\
(2)\end{array}$ & $\begin{array}{c}\text { Average Years } \\
\text { of Schooling } \\
\text { (3) }\end{array}$ & $\begin{array}{c}\text { Average Years } \\
\text { of Schooling } \\
(4)\end{array}$ & $\begin{array}{l}\text { Money/GDP } \\
(5)\end{array}$ & $\begin{array}{c}\text { Money/GDP } \\
(6)\end{array}$ & $\begin{array}{c}\text { Standard } \\
\text { deviation } \\
\text { terms of trade } \\
\times \text { export share } \\
(7) \\
\end{array}$ & $\begin{array}{c}\text { Standard } \\
\text { deviation terms } \\
\text { of trade } x \\
\text { export share } \\
(8) \\
\end{array}$ & $\begin{array}{c}\text { Without } \\
\text { Outliers } \\
\text { (9) }\end{array}$ & $\begin{array}{c}\text { Without } \\
\text { Outliers } \\
(10)\end{array}$ \\
\hline & \multicolumn{10}{|c|}{ Panel A: Cross-Section, 1970-97; instrumenting for institutions } \\
\hline Initial Constraint on the Executive & $\begin{array}{l}-0.48 \\
(0.21)\end{array}$ & $\begin{array}{l}-1.29 \\
(0.84)\end{array}$ & $\begin{array}{l}-1.54 \\
(1.24)\end{array}$ & $\begin{array}{l}-1.94 \\
(1.57)\end{array}$ & $\begin{array}{l}-0.77 \\
(0.33)\end{array}$ & $\begin{array}{l}-1.59 \\
(0.88)\end{array}$ & $\begin{array}{c}-0.74 \\
(0.22)\end{array}$ & $\begin{array}{l}-1.30 \\
(0.63)\end{array}$ & $\begin{array}{l}-0.71 \\
(0.17)\end{array}$ & $\begin{array}{l}-1.41 \\
(0.57)\end{array}$ \\
\hline Log Initial GDP per capita & & $\begin{array}{l}-1.63 \\
(1.25)\end{array}$ & & $\begin{array}{l}0.94 \\
(0.77)\end{array}$ & & $\begin{array}{l}0.08 \\
(1.19)\end{array}$ & & $\begin{array}{c}1.04 \\
(0.85)\end{array}$ & & $\begin{array}{l}1.35 \\
(0.82)\end{array}$ \\
\hline $\mathrm{p}$-value for macro variables & {$[0.25]$} & {$[0.17]$} & & & & & & & & \\
\hline Average Years of Schooling in 1970 & & & $\begin{array}{c}0.60 \\
(0.72)\end{array}$ & $\begin{array}{c}0.55 \\
(0.87)\end{array}$ & & & & & & \\
\hline Log Average Money/GDP Ratio & & & & & $\begin{array}{c}-0.21 \\
(0.84)\end{array}$ & $\begin{array}{c}1.46 \\
(0.99)\end{array}$ & & & & \\
\hline $\mathrm{p}$-value for terms of trade variables & & & & & & & {$[0.006]$} & {$[0.18]$} & & \\
\hline \multirow[t]{2}{*}{ Number of Observations } & 44 & 44 & 47 & 47 & 61 & 61 & 60 & 60 & 59 & 59 \\
\hline & \multicolumn{10}{|c|}{ Panel B: 5-year panels, 1970-97; instrumenting for institutions } \\
\hline Initial Constraint on the Executive & $\begin{array}{l}-0.88 \\
(0.30)\end{array}$ & $\begin{array}{l}-1.26 \\
(0.55)\end{array}$ & $\begin{array}{l}-1.54 \\
(1.09)\end{array}$ & $\begin{array}{l}-1.38 \\
(0.86)\end{array}$ & $\begin{array}{l}-0.65 \\
(0.20)\end{array}$ & $\begin{array}{l}-1.04 \\
(0.48)\end{array}$ & $\begin{array}{l}-0.87 \\
(0.22)\end{array}$ & $\begin{array}{l}-1.24 \\
(0.50)\end{array}$ & $\begin{array}{l}-0.58 \\
(0.13)\end{array}$ & $\begin{array}{l}-0.86 \\
(0.43)\end{array}$ \\
\hline Lagged log GNP per capita & & $\begin{array}{l}0.71 \\
(0.58)\end{array}$ & & $\begin{array}{l}-0.22 \\
(0.44)\end{array}$ & & $\begin{array}{l}0.54 \\
(0.41)\end{array}$ & & $\begin{array}{c}0.55 \\
(0.50)\end{array}$ & & $\begin{array}{c}0.28 \\
(0.25)\end{array}$ \\
\hline $\mathrm{p}$-value for macro variables & [0.99] & {$[0.69]$} & & & & & & & & \\
\hline Average Years of Schooling & & & $\begin{array}{c}0.61 \\
(0.57)\end{array}$ & $\begin{array}{c}0.61 \\
(0.54)\end{array}$ & & & & & & \\
\hline Log Average Money/GDP Ratio & & & & & $\begin{array}{l}-0.07 \\
(0.44)\end{array}$ & $\begin{array}{l}-0.11 \\
(0.51)\end{array}$ & & & & \\
\hline $\begin{array}{l}\text { Terms of trade shock } \\
\text { x export/GDP share }\end{array}$ & & & & & & & $\begin{array}{l}28.88 \\
(25.07)\end{array}$ & $\begin{array}{l}19.08 \\
(21.96)\end{array}$ & & \\
\hline Number of Countries & 58 & 58 & 47 & 47 & 61 & 61 & 60 & 60 & 59 & 59 \\
\hline
\end{tabular}

Standard errors are in parentheses. Panel A reports cross-sectional regressions with one observation per country; Panel B reports "5-year" unbalanced panels (1970-75, 1976-80, 1981-85, 1986-90, 1991-95, 1996-1997) with up to 6 observations per country. Panel B includes time dummies but not country dummies; we cluster the errors by country. In all Panels the dependent variable is standard deviation of real GDP per capita growth rate over either the whole period (Panel A) or the relevant "5-year" subperiod (Panel B). In Panel B log initial GDP per capita is the Summers-Heston estimate for 1970, from Barro and Lee (1993). In Panel B lagged log GNP per capita is at the start of each "5-year" period (1970 for 1970-75, etc); using GNP rather than GDP increases our sample size.

Columns 1 and 2 include: log average inflation, which is the log of average annual inflation in the Consumer Price Index from 1970 to 1997 (Panel A) and the log of average annual CPI inflation in each "5-year" period (Panel B), from the World Bank; and Government Consumption, which is the average of the ratio of real government "consumption" expenditure to real GDP from 1970 to 1989 (Panel A) and the average in each "5-year" period for which it is available (Panel B), from Barro and Lee (1993); and Real Exchange Rate Overvaluation (Panel A only), which is an index of real overvaluation of the official exchange rate during 1970-98, constructed by Easterly and Levine (2002) using the methodology of Dollar (1992). Columns 3 and 4 include average schooling years in the total population over age 25 for 1970 (Panel A) and each "5-year" period for which it is available (Panel B), from Barro and Lee (1993).

Columns 5 and 6 include the log of average money-GDP ratio for 1970-97 (Panel A) and for each "5-year" period (Panel B), from the World Bank. Columns 7 and 8 include the interactio of standard deviation of terms of trade shocks in 1970-89 times export-GDP ratio in 1970 (Panel A) and the standard deviation of terms of trade shocks times export-GDP ratio in each "5year" period (Panel B), from Barro and Lee (1993). The main effects are included in the regressions but not reported to save space. Columns 9 and 10 drop Rwanda and Gabon.

"Initial Constraint on the Executive" is average constraint on executive in 1950, 1960 and 1970, which is an average of the Polity score in each year; countries that are still colonies in a particular year are assigned a score of 1 . In both panels we instrument for institutions using log settler mortality (where mortality is per 1000 with replacement). All regressions use our Excolonies Sample which includes all former colonies of European Powers for which Acemoglu, Johnson and Robinson (2001) report data. For more detailed data definitions and sources see Appendix Table 1. 
Table 9

Institutions and Volatility: Other Controls and Samples

\begin{tabular}{|c|c|c|c|c|c|c|c|c|}
\hline & $\begin{array}{l}\text { Shareholders' } \\
\text { Rights } \\
\text { (1) } \\
\end{array}$ & $\begin{array}{c}\text { Shareholders' } \\
\text { Rights } \\
(2) \\
\end{array}$ & $\begin{array}{l}\text { Creditors' Rights } \\
\text { (3) }\end{array}$ & $\begin{array}{c}\text { Creditors' Rights } \\
(4)\end{array}$ & $\begin{array}{c}\text { Share of } \\
\text { primary exports } \\
\text { in GDP } \\
(5) \\
\end{array}$ & $\begin{array}{c}\text { Share of } \\
\text { primary exports } \\
\text { in GDP } \\
(6) \\
\end{array}$ & $\begin{array}{l}\text { Latitude } \\
\text { (7) }\end{array}$ & $\begin{array}{l}\text { Latitude } \\
\qquad(8)\end{array}$ \\
\hline Initial Constraint on the Executive & $\begin{array}{l}-1.18 \\
(0.49)\end{array}$ & $\begin{array}{l}-2.18 \\
(1.33)\end{array}$ & $\begin{array}{l}-0.92 \\
(0.33)\end{array}$ & $\begin{array}{l}-1.79 \\
(0.95)\end{array}$ & $\begin{array}{l}-0.82 \\
(0.21)\end{array}$ & $\begin{array}{l}-1.65 \\
(0.67)\end{array}$ & $\begin{array}{l}-0.77 \\
(0.25)\end{array}$ & $\begin{array}{l}-1.48 \\
(0.62)\end{array}$ \\
\hline Log Initial GDP per capita & & $\begin{array}{c}1.41 \\
(1.18)\end{array}$ & & $\begin{array}{c}1.81 \\
(1.41)\end{array}$ & & $\begin{array}{l}1.58 \\
(0.96)\end{array}$ & & $\begin{array}{l}1.42 \\
(0.81)\end{array}$ \\
\hline Creditors' Rights & & & $\begin{array}{l}-0.13 \\
(0.23)\end{array}$ & $\begin{array}{l}0.42 \\
(0.56)\end{array}$ & & & & \\
\hline $\begin{array}{l}\text { Share of exports of primary products } \\
\text { in GNP in } 1970\end{array}$ & & & & & $\begin{array}{l}1.65 \\
(2.40)\end{array}$ & $\begin{array}{l}(0.09) \\
(3.36)\end{array}$ & & \\
\hline Latitude & & & & & & & $\begin{array}{l}1.08 \\
(2.19)\end{array}$ & $\begin{array}{l}-1.43 \\
(2.63)\end{array}$ \\
\hline Initial Constraint on the Executive & $\begin{array}{l}-0.76 \\
(0.24)\end{array}$ & $\begin{array}{l}-1.34 \\
(0.83)\end{array}$ & $\begin{array}{l}-0.99 \\
(0.36)\end{array}$ & $\begin{array}{l}-1.77 \\
(0.83)\end{array}$ & $\begin{array}{l}-0.70 \\
(0.24)\end{array}$ & $\begin{array}{l}-1.24 \\
(0.47)\end{array}$ & $\begin{array}{l}-1.46 \\
(0.77)\end{array}$ & $\begin{array}{l}-1.03 \\
(0.77)\end{array}$ \\
\hline Log Initial GDP per capita & & $\begin{array}{c}1.11 \\
(1.18)\end{array}$ & & $\begin{array}{l}1.40 \\
(0.89)\end{array}$ & & $\begin{array}{l}1.41 \\
(0.64)\end{array}$ & & $\begin{array}{l}-1.04 \\
(0.81)\end{array}$ \\
\hline Number of Observations & 20 & 20 & 57 & 57 & 34 & 34 & 36 & 36 \\
\hline
\end{tabular}

Standard errors are in parentheses. Cross-sectional regressions with one observation per country. The dependent variable is standard deviation of real GDP per capita growth rate over 1970-97. Log initial GDP per capita is the Summers Heston estimate for 1970, from Barro-Lee.

Columns 1 and 2 include the measure of "anti-director rights" (i.e., shareholders' rights relative to directors) from La Porta, Lopez-de-Silanes, Shleifer, and Vishny (1998), where a higher score indicates stronger rights for shareholders. Columns 3 and 4 include a measure of creditor rights, in which a higher score indicates stronger rights for creditors, from La Porta et al (1998). Columns 5 and 6 include the share of primary exports in GDP in 1970 from Sachs and Warner (1997). Columns 7 and 8 include the absolute normalized value of distance from the equator (i.e., a standardized measure of latitude), in which a higher value indicates that a country's capital is further from the equator.

Columns 9 and 10 include just Common Law countries (British legal origin), from La Porta et al (1998). Columns 11 and 12 include just former European colonies, but drop the USA, Canada, Australia and New Zealand. Columns 13 and 14 drop all countries in Africa. Columns 15 and 16 include just countries below the median world per capita income level in 1970, using the Summers-Heston measure from Barro and Lee (1993).

"Initial Constraint on the Executive" is average constraint on executive in 1950, 1960 and 1970, which is an average of the Polity score in each year; countries that are still colonies in a particular year are assigned a score of 1 . In all regressions we instrument for institutions using log settler mortality (where mortality is per 1000 with replacement). All regressions use our Excolonies Sample which includes all former colonies of European Powers for which Acemoglu, Johnson and Robinson (2001) report data. For more detailed data definitions and sources see Appendix Table 1. 
Table 10

Institutions and Economic Stability: Results by Decade

\begin{tabular}{|c|c|c|c|c|c|c|}
\hline & \multicolumn{6}{|c|}{ Dependent Variable is } \\
\hline & \multicolumn{2}{|c|}{$\begin{array}{l}\text { Standard deviation of Growth } \\
\text { Rate of real GDP per capita }\end{array}$} & \multicolumn{2}{|c|}{$\begin{array}{l}\text { Worst Drop Output (GDP per } \\
\text { capita) }\end{array}$} & \multicolumn{2}{|c|}{$\begin{array}{c}\text { Growth of Real GDP per } \\
\text { capita }\end{array}$} \\
\hline & $(1)$ & $(2)$ & $(3)$ & $(4)$ & $(5)$ & $(6)$ \\
\hline & \multicolumn{6}{|c|}{ Panel A: Cross-Section for 1970s } \\
\hline Initial Constraint on the Executive & $\begin{array}{l}-1.06 \\
(0.37)\end{array}$ & $\begin{array}{l}-1.92 \\
(0.96)\end{array}$ & $\begin{array}{c}-1.94 \\
(0.86)\end{array}$ & $\begin{array}{l}-3.45 \\
(2.14)\end{array}$ & $\begin{array}{c}0.30 \\
(0.30)\end{array}$ & $\begin{array}{c}0.43 \\
(0.66)\end{array}$ \\
\hline Log Initial GDP per capita & & $\begin{array}{l}1.72 \\
(1.35)\end{array}$ & & $\begin{array}{l}2.99 \\
(3.02)\end{array}$ & & $\begin{array}{l}-0.25 \\
(0.93)\end{array}$ \\
\hline Number of Observations & 54 & 54 & 54 & 54 & 54 & 54 \\
\hline Initial Constraint on the Executive & $\begin{array}{l}-0.70 \\
(0.26)\end{array}$ & $\begin{array}{l}-1.90 \\
(0.78)\end{array}$ & $\begin{array}{c}\text { nel B: Cros } \\
-2.01 \\
(0.71)\end{array}$ & $\begin{array}{l}\text { on for } 198 \\
-5.30 \\
(2.21)\end{array}$ & $\begin{array}{c}0.86 \\
(0.30)\end{array}$ & $\begin{array}{c}1.68 \\
(0.77)\end{array}$ \\
\hline Log Initial GDP per capita & & $\begin{array}{l}2.30 \\
(1.07)\end{array}$ & & $\begin{array}{c}6.30 \\
(3.04)\end{array}$ & & $\begin{array}{l}-1.57 \\
(1.06)\end{array}$ \\
\hline \multirow[t]{2}{*}{ Number of Observations } & 54 & 54 & 54 & 54 & 54 & 54 \\
\hline & \multicolumn{6}{|c|}{ Panel C: Cross-Section for 1990s } \\
\hline Initial Constraint on the Executive & $\begin{array}{l}-0.46 \\
(0.25)\end{array}$ & $\begin{array}{l}-0.85 \\
(0.70)\end{array}$ & $\begin{array}{c}-1.46 \\
(0.57)\end{array}$ & $\begin{array}{l}-3.13 \\
(1.90)\end{array}$ & $\begin{array}{c}0.81 \\
(0.32)\end{array}$ & $\begin{array}{c}1.63 \\
(1.07)\end{array}$ \\
\hline Log Initial GDP per capita & & $\begin{array}{l}0.71 \\
(0.97)\end{array}$ & & $\begin{array}{l}2.97 \\
(2.66)\end{array}$ & & $\begin{array}{l}-1.47 \\
(1.50)\end{array}$ \\
\hline Number of Observations & 47 & 47 & 47 & 47 & 47 & 47 \\
\hline
\end{tabular}

Standard errors are in parentheses. All regressions are cross-sectional regressions with one observation per country. In columns 1 and 2 the dependent variable is standard deviation of GDP per capita growth rate, from the World Bank. In columns 3 and 4 the dependent variable is the lowest annual growth rate of GDP per capita (with the sign changed so that an output fall is a positive number), from the World Bank. In columns 5 and 6 the dependent variable is the average annual GDP per capita growth rate. In Panel A we use outcomes for 1970-79, in Panel B we use outcomes for 1980-89, and in Panel C we use outcomes for 1990-97. Log initial GDP per capita is the Summers-Heston estimate for 1970 (Panel A), 1980 (Panel B), and 1990 (Panel C), from Barro and Lee (1993).

"Initial Constraint on the Executive" is average constraint on executive in 1950, 1960 and 1970, which is an average of the Polity score in each year; countries that are still colonies in a particular year are assigned a score of 1 . In all panels we instrument for institutions using log settler mortality (where mortality is per 1000 with replacement). All regressions use our Excolonies Sample, including all former colonies of European Powers for which Acemoglu, Johnson and Robinson (2001) report data. For more detailed data definitions and sources see Appendix Table 1. 
Table 11

Global Shocks and Institutions: Panel Results

\begin{tabular}{|c|c|c|c|c|c|c|c|c|}
\hline & $\begin{array}{l}\text { No Fixed Effects } \\
\text { (1) }\end{array}$ & $\begin{array}{l}\text { Fixed Effects } \\
\text { (2) }\end{array}$ & $\begin{array}{l}\text { No Fixed Effects } \\
\text { (3) }\end{array}$ & $\begin{array}{l}\text { Fixed Effects } \\
\text { (4) }\end{array}$ & $\begin{array}{c}\text { No Fixed Effects } \\
\text { (5) }\end{array}$ & $\begin{array}{l}\text { Fixed Effects } \\
\text { (6) }\end{array}$ & $\begin{array}{l}\text { No Fixed Effects } \\
\text { (7) }\end{array}$ & $\begin{array}{l}\text { Fixed Effects } \\
\text { (8) }\end{array}$ \\
\hline & \multicolumn{8}{|c|}{ Dependent Variable is: } \\
\hline & \multicolumn{4}{|c|}{ Standard deviation of Growth Rate of real GDP per capita } & \multicolumn{4}{|c|}{ Growth of Real GDP per capita } \\
\hline \multirow[b]{2}{*}{ Initial Constraint on the Executive } & \multicolumn{2}{|c|}{$\begin{array}{l}\text { Using World Growth as World } \\
\text { Economy varaible }\end{array}$} & \multicolumn{2}{|c|}{$\begin{array}{c}\text { Using World Trade as World } \\
\text { Economy variable }\end{array}$} & \multicolumn{2}{|c|}{$\begin{array}{l}\text { Using World Growth as } \\
\text { World Economy varaible }\end{array}$} & \multicolumn{2}{|c|}{$\begin{array}{l}\text { Using World Trade as } \\
\text { World Economy variable }\end{array}$} \\
\hline & $\begin{array}{l}-0.59 \\
(0.13)\end{array}$ & & $\begin{array}{l}-0.60 \\
(0.14)\end{array}$ & & $\begin{array}{l}0.74 \\
(0.23)\end{array}$ & & $\begin{array}{c}0.73 \\
(0.23)\end{array}$ & \\
\hline $\begin{array}{l}\text { Initial Constraint on the Executive } \\
\mathrm{x} \text { world economy variable }\end{array}$ & $\begin{array}{l}-15.67 \\
(19.86)\end{array}$ & $\begin{array}{l}-11.11 \\
(18.63)\end{array}$ & $\begin{array}{l}0.021 \\
(0.067)\end{array}$ & $\begin{array}{c}0.012 \\
(0.092)\end{array}$ & $\begin{array}{l}-38.66 \\
(17.34)\end{array}$ & $\begin{array}{l}-40.19 \\
(18.79)\end{array}$ & $\begin{array}{l}-0.01 \\
(0.10)\end{array}$ & $\begin{array}{c}-6.36 \\
(47.51)\end{array}$ \\
\hline Number of Countries & 71 & 71 & 71 & 71 & 71 & 71 & 71 & 71 \\
\hline
\end{tabular}

Standard errors are in parentheses. Dependent Variable is standard deviation of GDP per capita growth rate in "5-year" periods (1970-75, 1976-80, 1981-85, 1986-90, 1991-95, 1996-97) in columns 1 through 4 and growth rates of GDP per capita in "5-year" periods in columns 5 through 8 , both from the World Bank. World growth is annual change in gross domestic product, market exchange rate weighted, from the IMF website. World trade growth is trade volume of goods and services, from the IMF. Both world growth and world trade growth are annual growth rates averaged over the relevant "5-year" period. All regressions include period dummies. Odd numbered columns do not use fixed effects and cluster the errors by country. Even numbered columns use fixed effects.

Initial Constraint on the Executive is average constraint on executive in 1950, 1960 and 1970, which is an average of the Polity score in each year; countries that are still colonies in a particular year are assigned a score of 1 . In all regressions we instrument for institutions using log settler mortality (where mortality is deaths per annum per 1000 with replacement). All regressions use our Excolonies Sample, which includes all former colonies of European Powers for which Acemoglu, Johnson and Robinson (2001) report data. For more detailed data definitions and sources see Appendix Table 1. 
Table 12

Institutions, State Failures and Volatility

\begin{tabular}{|c|c|c|c|c|c|c|c|c|}
\hline & (1) & (2) & (3) & (4) & (5) & (6) & (7) & (8) \\
\hline \multicolumn{9}{|c|}{ Panel A: Dependent Variable is State Failure Dummy } \\
\hline & \multicolumn{2}{|c|}{ State Failure in 1970-98 } & \multicolumn{2}{|c|}{ State Failure in 1970-79 } & \multicolumn{2}{|c|}{ State Failure in $1980-89$} & \multicolumn{2}{|c|}{ State Failure in $1990-97$} \\
\hline Initial Constraint on the Executive & $\begin{array}{c}0.11 \\
(0.054)\end{array}$ & $\begin{array}{l}-0.058 \\
(0.12)\end{array}$ & $\begin{array}{l}-0.019 \\
(0.050)\end{array}$ & $\begin{array}{l}0.047 \\
(0.12)\end{array}$ & $\begin{array}{l}-0.060 \\
(0.039)\end{array}$ & $\begin{array}{l}-0.032 \\
(0.086)\end{array}$ & $\begin{array}{l}-0.072 \\
(0.039)\end{array}$ & $\begin{array}{l}-0.031 \\
(0.11)\end{array}$ \\
\hline Log Initial GDP per capita & & $\begin{array}{l}-0.11 \\
(0.17)\end{array}$ & & $\begin{array}{l}-0.13 \\
(0.17)\end{array}$ & & $\begin{array}{l}-0.050 \\
(0.12)\end{array}$ & & $\begin{array}{r}-0.068 \\
(0.15)\end{array}$ \\
\hline \multirow[t]{3}{*}{ Number of Observations } & 61 & 61 & 61 & 61 & 61 & 61 & 53 & 53 \\
\hline & \multicolumn{6}{|c|}{ Panel B: Cross-Section for 1970-97, dependent variable: } & & \\
\hline & \multicolumn{2}{|c|}{$\begin{array}{l}\text { Standard deviation of Growth } \\
\text { Rate of real GNP per capita }\end{array}$} & \multicolumn{2}{|c|}{$\begin{array}{l}\text { Worst Drop Output (GNP per } \\
\text { capita) }\end{array}$} & \multicolumn{2}{|c|}{$\begin{array}{c}\text { Growth of Real GNP per } \\
\text { capita }\end{array}$} & & \\
\hline Initial Constraint on the Executive & $\begin{array}{l}-0.83 \\
(0.23)\end{array}$ & $\begin{array}{l}-1.56 \\
(0.60)\end{array}$ & $\begin{array}{l}-2.19 \\
(0.78)\end{array}$ & $\begin{array}{l}-4.56 \\
(2.06)\end{array}$ & $\begin{array}{c}0.73 \\
(0.25)\end{array}$ & $\begin{array}{c}1.54 \\
(0.72)\end{array}$ & & \\
\hline State Failure Dummy & $\begin{array}{l}0.003 \\
(0.54)\end{array}$ & $\begin{array}{l}0.07 \\
(0.67)\end{array}$ & $\begin{array}{l}2.36 \\
(1.87)\end{array}$ & $\begin{array}{l}2.58 \\
(2.31)\end{array}$ & $\begin{array}{l}-0.33 \\
(0.59)\end{array}$ & $\begin{array}{l}-0.40 \\
(0.81)\end{array}$ & & \\
\hline Log Initial GDP per capita & & $\begin{array}{c}1.45 \\
(0.82)\end{array}$ & & $\begin{array}{l}4.71 \\
(2.83)\end{array}$ & & $\begin{array}{l}-1.62 \\
(0.98)\end{array}$ & & \\
\hline \multirow[t]{3}{*}{ Number of Observations } & 61 & 61 & 61 & 61 & 61 & 61 & & \\
\hline & \multicolumn{6}{|c|}{ Panel C: 5-year Panels for 1970-97, dependent variable: } & & \\
\hline & $\begin{array}{l}\text { Standard d } \\
\text { Rate of re } \\
\end{array}$ & $\begin{array}{l}n \text { of Growth } \\
\text { per capita }\end{array}$ & Worst Drop & it (GNP per & Growth & GNP per & & \\
\hline Initial Constraint on the Executive & $\begin{array}{l}-0.60 \\
(0.14)\end{array}$ & $\begin{array}{l}-1.06 \\
(0.41)\end{array}$ & $\begin{array}{l}-1.27 \\
(0.34)\end{array}$ & $\begin{array}{l}-2.32 \\
(0.81)\end{array}$ & $\begin{array}{c}0.66 \\
(0.23)\end{array}$ & $\begin{array}{l}1.05 \\
(0.41)\end{array}$ & & \\
\hline State Failure Dummy & $\begin{array}{l}1.24 \\
(0.70)\end{array}$ & $\begin{array}{l}1.25 \\
(0.73)\end{array}$ & $\begin{array}{c}3.88 \\
(1.20)\end{array}$ & $\begin{array}{c}3.89 \\
(1.33)\end{array}$ & $\begin{array}{l}-2.28 \\
(0.63)\end{array}$ & $\begin{array}{l}-2.28 \\
(0.67)\end{array}$ & & \\
\hline Lagged log GNP per capita & & $\begin{array}{c}0.60 \\
(0.40)\end{array}$ & & $\begin{array}{c}1.38 \\
(0.78)\end{array}$ & & $\begin{array}{c}-0.51 \\
(0.40)\end{array}$ & & \\
\hline Number of Countries & 61 & 61 & 61 & 61 & 61 & 61 & & \\
\hline
\end{tabular}

Standard errors are in parentheses. Panels A and B are cross-sectional regressions with one observation per country. Panel C is "5-year" unbalanced panels (1970-75, 1976-80, 1981-85, 1986-90, 1991-95, 1996-1997) with up to 6 observations per country. Panel C includes time dummies but not country

dummies; we cluster the errors by country. In Panel A the dependent variable is a dummy variable equal to one if the country experience a "State Failure", i.e., a civil war, breakdown of social order, major ethnic conflict or major regime transition as defined by the State Failure Project. For Panel A, the dummy equals one if there was a State Failure in 1970-98 (columns 1 and 2), in 1970-79 (columns 3 and 4), in 1980-89 (columns 5 and 6), and in 1990-97 (columns 7 and 8).

In Panels B and C, columns 1 and 2, the dependent variable is standard deviation of GDP per capita growth rate in 1970-97 (Panel B) and in each "5-year" period (Panel C), from the World Bank. In Panels B and C, columns 3 and 4, the dependent variable is the lowest annual growth rate of GDP per capita (with the sign changed so that an output fall is a positive number) in 1970-97 (Panel B) and each "5-year" period (Panel C), from the World Bank. In

Panels B and C, columns 5 and 6, the dependent variable is the average annual GDP per capita growth rate in 1970-97 (Panel B) and each "5-year" period (Panel C).

Log initial GDP per capita is the Summers-Heston estimate for 1970 (Panels A and B), from Barro and Lee (1993). In Panel C lagged log GNP per capita is at the start of each "5-year" period (1970 for 1970-75, etc); using GNP rather than GDP increases our sample size. "Initial Constraint on the Executive" is average constraint on executive in 1950, 1960 and 1970, which is an average of the Polity score in each year; countries that are still colonies in a particular year are assigned a score of 1 . In both panels we instrument for institutions using log settler mortality (where mortality is per 1000 with replacement).

All regressions use our Excolonies Sample which includes all former colonies of European Powers for which Acemoglu, Johnson and Robinson (2001) report data. For more detailed data definitions and sources see Appendix Table 1. 
Appendix Table A1

Variable Definitions and Sources

\begin{tabular}{|c|c|c|}
\hline Variable & Description & Source \\
\hline Log GDP per capita (PPP) in 1995 & Logarithm of GDP per capita, on Purchasing Power Parity Basis, in 1995. & $\begin{array}{l}\text { World Bank, World Development Indicators, CD-Rom, 1999. Data on Suriname is } \\
\text { from the } 2000 \text { version of this same source. }\end{array}$ \\
\hline Log GDP per capita in 1970 & Logarithm of real GDP per capita (1980 international prices) from Summers Heston dataset v.4.0. & $\begin{array}{l}\text { Barro-Lee dataset, used in Barro and Lee (1993) and available from the NBER website: } \\
\text { www.nber.org. }\end{array}$ \\
\hline Log GDP per capita in 1980 & Logarithm of real GDP per capita (1985 international prices) from Summers Heston dataset v.5.5. & Barro-Lee dataset. \\
\hline Log GDP per capita in 1990 & Logarithm of real GDP per capita (1985 international prices) from Summers Heston dataset v.5.5. & Barro-Lee dataset. \\
\hline Growth Rate of GDP per capita, 1970-98 & Annual GDP growth rate minus annual population growth rate. & World Bank, World Development Indicators, CD-Rom, 1999. \\
\hline Standard Deviation of Growth & Standard deviation of GDP per capita growth rate. & $\begin{array}{l}\text { Calculated from the Growth Rate of GDP per capita. From the World Bank, World } \\
\text { Development Indicators, CD-Rom, } 1999 .\end{array}$ \\
\hline $\begin{array}{l}\text { Log GNP per capita, 1970, 1975, 1980, 1985, 1990, } \\
1995\end{array}$ & Logarithm of GNP per capita & $\begin{array}{l}\text { World Bank, World Development Indicators, CD-Rom, 1999. Data on Suriname is } \\
\text { from the } 2000 \text { version of this same source. }\end{array}$ \\
\hline $\begin{array}{l}\text { Constraint on Executive in 1950, 1960, 1970, } 1990 \text { and } \\
\text { intervening years. }\end{array}$ & $\begin{array}{l}\text { A seven category scale, from } 1 \text { to } 7 \text {, with a higher score indicating more constraints. Score of } 1 \text { indicates unlimited } \\
\text { authority; score of } 3 \text { indicates slight to moderate limitations; score of } 5 \text { indicates substantial limitations; score of } 7 \text { indicates } \\
\text { executive parity or subordination. Scores of } 2,4 \text {, and } 6 \text { indicate intermediate values. }\end{array}$ & $\begin{array}{l}\text { Polity IV dataset, downloaded from Inter-University Consortium for Political and Social } \\
\text { Research. Variable described in Gurr } 1997 .\end{array}$ \\
\hline Average Protection against Expropriation Risk, $1985-95$ & $\begin{array}{l}\text { Risk of expropriation of private foreign investment by government, from } 0 \text { to } 10 \text {, where a higher score means less risk. We } \\
\text { calculated the mean value for the scores in all years from } 1985 \text { to } 1995 \text {. }\end{array}$ & $\begin{array}{l}\text { Dataset obtained directly from Political Risk Services, September 1999. These data } \\
\text { were previously used by Knack and Keefer (1995) and were organized in electronic } \\
\text { form by the IRIS Center (University of Maryland). The original compilers of this data } \\
\text { are Political Risk Services. }\end{array}$ \\
\hline $\begin{array}{l}\text { Constraints on Executive in } 1950,1960,1970 \text {, and } \\
1990 .\end{array}$ & $\begin{array}{l}\text { A seven category scale, from } 1 \text { to } 7 \text {, with a higher score indicating more constraints. Score of } 1 \text { indicates unlimited } \\
\text { authority; score of } 3 \text { indicates slight to moderate limitations; score of } 5 \text { indicates substantial limitations; score of } 7 \text { indicates } \\
\text { execut }\end{array}$ & $\begin{array}{l}\text { Polity III dataset, downloaded from Inter-University Consortium for Political and Social } \\
\text { Research. Variable described in Gurr } 1997 .\end{array}$ \\
\hline $\begin{array}{l}\text { Log Average Inflation } \\
\text { Government Consumption }\end{array}$ & $\begin{array}{l}\text { Log of average annual inflation in the Consumer Price Index from } 1970 \text { to } 1998 . \\
\text { Average of the ratio of real government "consumption" expenditure to real GDP from } 1970 \text { to } 1989 .\end{array}$ & $\begin{array}{l}\text { World Bank, World Development Indicators, CD-Rom, } 1999 . \\
\text { Barro-Lee dataset. }\end{array}$ \\
\hline Real Exchange Rate Overvaluation & An index of real overvaluation of the official exchange rate in 1960-97. & Easterly and Levine (2002) using the methodology of Dollar (1992). \\
\hline Variability of Real Exchange Rate Overvaluation & Standard deviation of an index of real overvaluation of the official exchange rate in 1976-85. & Dollar (1992). \\
\hline Average Years of Schooling & Average schooling years in the total population over age 25 for 1970 & Barro-Lee dataset. \\
\hline Money/GDP & Log of average Money-GDP ratio for 1970-97 (and subperiods where specified) & World Bank, World Development Indicators, CD-Rom, 1999. \\
\hline Shareholders' Rights & $\begin{array}{l}\text { An index aggregating the shareholder rights which La Porta et al label as "anti-director rights." The index is formed by } \\
\text { adding } 1 \text { when: (1) the country allows shareholders to mail their proxy vote; ; } 2 \text { shareholders are not required to deposit their } \\
\text { shares prior to the General Shareholders' Meeting; (3) cumulative voting is allowed; (4) an oppressed minorities mechanism } \\
\text { is in place, or (5) when the minimum percentage of share capital that entitles a shareholder to call for an Extraordinary } \\
\text { Shareholders' Meeting is less than or equal to } 10 \% \text { (the sample median). The index ranges from } 0 \text { to } 5 \text {. }\end{array}$ & La Porta, Lopez-de-Silanes, Shleifer and Vishny 1998. \\
\hline Creditors' Rights & $\begin{array}{l}\text { An index aggregating creditor rights. The index is formed by adding } 1 \text { when: (1) the country imposes restrictions, such as } \\
\text { creditors' consent or minimum dividends, to file for reorganization; (2) secured creditors are able to gain possession of their } \\
\text { security once the reorganization petition has been approved (no automatic stay); (3) the debtor does not retain the } \\
\text { administration of fits property pending the resolution of the reorganization; ; } 4 \text { secured creditors are ranked first th the } \\
\text { distribution of the proceeds that result from the disposition of the assets of a bankrupt firm. The index ranges from } 0 \text { to } 4 \text {. }\end{array}$ & La Porta, Lopez-de-Silanes, Shleifer and Vishny 1998. \\
\hline Standard deviation of terms of trade shocks & Standard deviation of an index of terms of trade shock, 1970-89 (and subperiods where specified) & Barro-Lee dataset. \\
\hline Export/GDP & Ratio of exports to GDP in 1970 (and other dates where specified) & Barro-Lee dataset. \\
\hline World Growth & Growth rate of World GDP & IMF (online) \\
\hline World Trade Growth & Growth rate of World Trade & IMF (online) \\
\hline Log Settler Mortality & $\begin{array}{l}\text { Log of estimated mortality for European settlers during the early period of European colonization (before 1850). Settler } \\
\text { mortality is calculated from the mortality rates of European-born soldiers, sailors and bishops when stationed in colonies. It } \\
\text { measures the effects of local diseases on people without inherited or acquired imm }\end{array}$ & Acemoglu, Johnson and Robinson (2001), based on Curtin (1989) and other sources. \\
\hline
\end{tabular}


Table A2

Descriptive Statistics

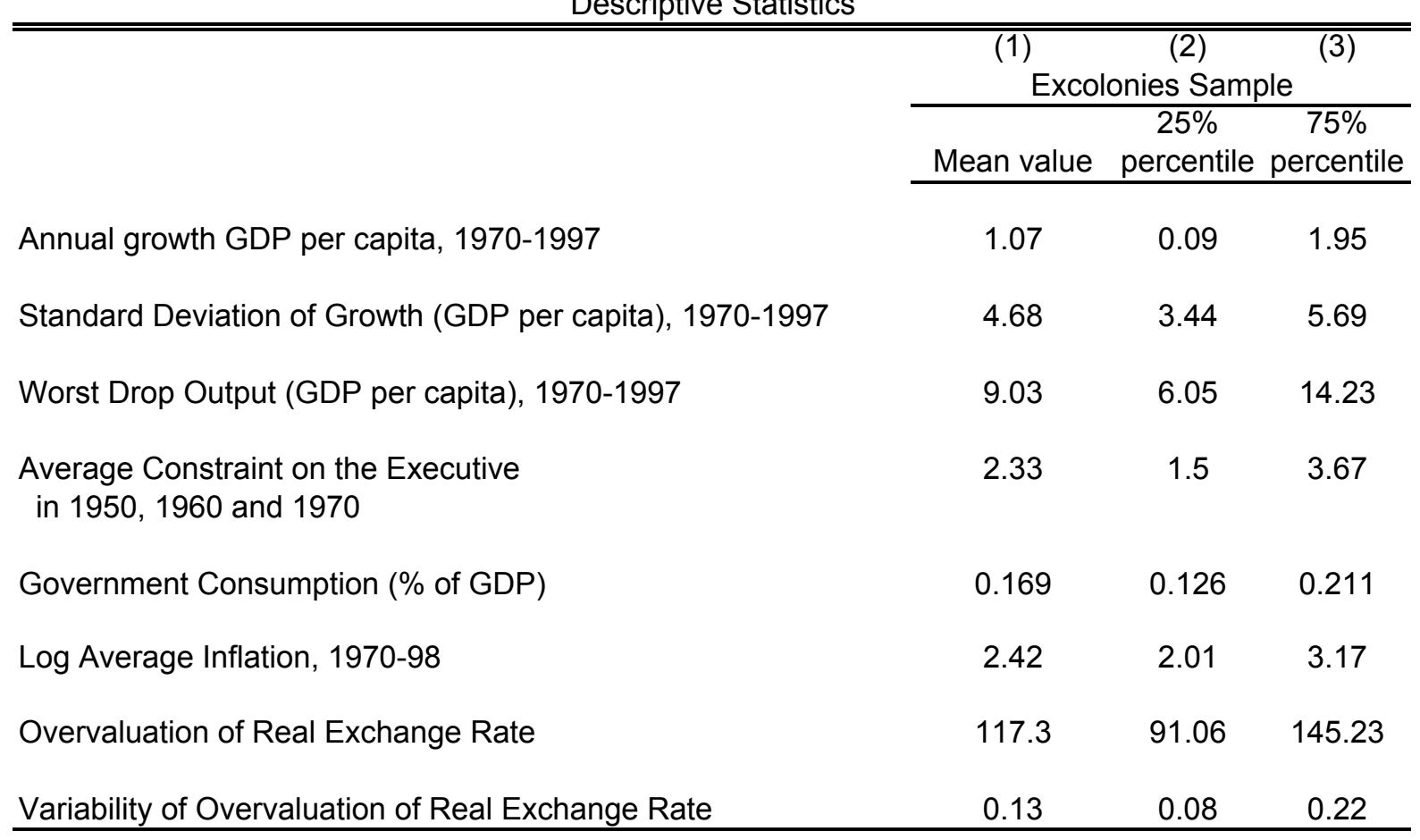

For detailed sources and definitions see Appendix Table A1. 
Table A3

Volatility, Institutions in 1970 and the Three Macroeconomic Variables

Dependent Variable is standard deviation of growth rate of real GDP per capita between 1970 and 1997

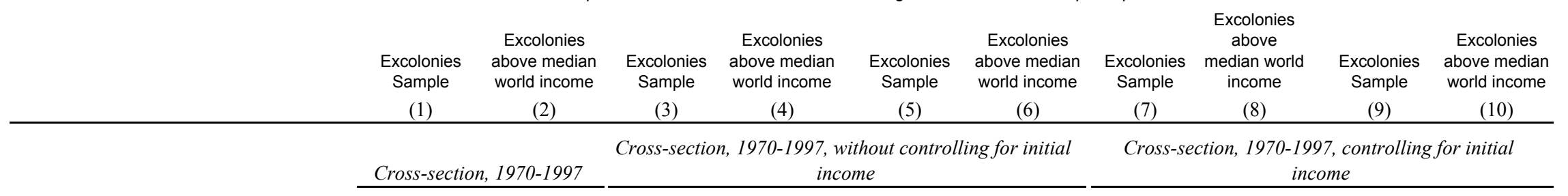

\begin{tabular}{|c|c|c|c|c|c|c|c|c|c|c|}
\hline \multirow[b]{3}{*}{ Government Consumption } & \multicolumn{2}{|c|}{ Institutions only } & \multicolumn{2}{|c|}{$\begin{array}{c}\text { Macro and Institutions; } \\
\text { instrumenting for institutions }\end{array}$} & \multicolumn{2}{|c|}{$\begin{array}{l}\text { Macro and Institutions; } \\
\text { instrumenting for both }\end{array}$} & \multicolumn{2}{|c|}{$\begin{array}{l}\text { Macro and Institutions; } \\
\text { instrumenting for institutions }\end{array}$} & \multicolumn{2}{|c|}{$\begin{array}{l}\text { Macro and Institutions; } \\
\text { instrumenting for both }\end{array}$} \\
\hline & \multicolumn{10}{|c|}{ Panel A: Macroeconomic Variable is Government Consumption } \\
\hline & & & $\begin{array}{c}1.78 \\
(4.65)\end{array}$ & $\begin{array}{c}2.74 \\
(6.88)\end{array}$ & $\begin{array}{l}-6.86 \\
(6.79)\end{array}$ & $\begin{array}{l}-9.20 \\
(12.10)\end{array}$ & $\begin{array}{c}6.50 \\
(7.33)\end{array}$ & $\begin{array}{c}12.01 \\
(13.68)\end{array}$ & $\begin{array}{l}-3.74 \\
(10.05)\end{array}$ & $\begin{array}{l}-10.34 \\
(20.93)\end{array}$ \\
\hline Log Initial GDP per capita & & & & & & & $\begin{array}{c}1.95 \\
(1.42)\end{array}$ & $\begin{array}{c}4.35 \\
(4.52)\end{array}$ & $\begin{array}{c}1.77 \\
(1.49)\end{array}$ & $\begin{array}{c}3.80 \\
(4.84)\end{array}$ \\
\hline Constraint on the Executive in 1970 & $\begin{array}{l}-0.86 \\
(0.25)\end{array}$ & $\begin{array}{l}-0.92 \\
(0.41)\end{array}$ & $\begin{array}{l}-0.83 \\
(0.28)\end{array}$ & $\begin{array}{l}-0.88 \\
(0.42)\end{array}$ & $\begin{array}{l}-0.99 \\
(0.33)\end{array}$ & $\begin{array}{l}-1.06 \\
(0.59)\end{array}$ & $\begin{array}{l}-1.77 \\
(0.99)\end{array}$ & $\begin{array}{l}-1.91 \\
(1.68)\end{array}$ & $\begin{array}{l}-1.87 \\
(1.07)\end{array}$ & $\begin{array}{l}-2.10 \\
(2.12)\end{array}$ \\
\hline \multirow[t]{2}{*}{ Number of Observations } & 61 & 24 & 61 & 24 & 60 & 24 & 61 & 24 & 60 & 24 \\
\hline & \multicolumn{10}{|c|}{ Panel B: Macroeconomic Variable is Log Average Inflation } \\
\hline Log Average Inflation & & & $\begin{array}{l}-0.08 \\
(0.21)\end{array}$ & $\begin{array}{c}0.07 \\
(0.39)\end{array}$ & $\begin{array}{l}-0.31 \\
(0.55)\end{array}$ & $\begin{array}{c}0.52 \\
(0.52)\end{array}$ & $\begin{array}{l}-0.47 \\
(0.52)\end{array}$ & $\begin{array}{l}-2.98 \\
(5.71)\end{array}$ & $\begin{array}{l}-0.37 \\
(0.94)\end{array}$ & $\begin{array}{c}0.09 \\
(2.27)\end{array}$ \\
\hline Log Initial GDP per capita & $\begin{array}{c}1.73 \\
(1.38)\end{array}$ & $\begin{array}{c}4.05 \\
(4.56)\end{array}$ & & & & & $\begin{array}{c}2.03 \\
(1.71)\end{array}$ & $\begin{array}{c}6.09 \\
(12.87)\end{array}$ & $\begin{array}{c}2.23 \\
(1.95)\end{array}$ & $\begin{array}{c}6.61 \\
(16.63)\end{array}$ \\
\hline Constraint on the Executive in 1970 & $\begin{array}{l}-1.77 \\
(0.98)\end{array}$ & $\begin{array}{l}-2.01 \\
(1.81)\end{array}$ & $\begin{array}{l}-0.86 \\
(0.26)\end{array}$ & $\begin{array}{l}-0.87 \\
(0.54)\end{array}$ & $\begin{array}{l}-1.03 \\
(0.34)\end{array}$ & $\begin{array}{l}-0.75 \\
(0.68)\end{array}$ & $\begin{array}{l}-1.94 \\
(1.19)\end{array}$ & $\begin{array}{l}-2.98 \\
(5.71)\end{array}$ & $\begin{array}{l}-2.17 \\
(1.41)\end{array}$ & $\begin{array}{l}-3.19 \\
(7.94)\end{array}$ \\
\hline \multirow[t]{2}{*}{ Number of Observations } & 61 & 24 & 61 & 24 & 49 & 20 & 61 & 24 & 48 & 19 \\
\hline & \multicolumn{10}{|c|}{ Panel C: Macroeconomic Variable is Overvaluation of Real Exchange Rate } \\
\hline Real Exchange Rate Overvaluation & & & $\begin{array}{r}0.0075 \\
(0.02)\end{array}$ & $\begin{array}{l}-0.020 \\
(0.05)\end{array}$ & $\begin{array}{l}0.009 \\
(0.04)\end{array}$ & $\begin{array}{c}0.05 \\
(0.10)\end{array}$ & $\begin{array}{l}-0.020 \\
(0.078)\end{array}$ & $\begin{array}{l}-0.280 \\
(1.236)\end{array}$ & $\begin{array}{c}0.03 \\
(0.04)\end{array}$ & $\begin{array}{c}0.02 \\
(0.53)\end{array}$ \\
\hline Log Initial GDP per capita & & & & & & & $\begin{array}{l}2.35 \\
(4.11)\end{array}$ & $\begin{array}{c}15.60 \\
(63.22)\end{array}$ & $\begin{array}{c}1.58 \\
(1.44)\end{array}$ & $\begin{array}{c}14.05 \\
(67.11)\end{array}$ \\
\hline Constraint on the Executive in 1970 & & & $\begin{array}{l}-0.68 \\
(0.41)\end{array}$ & $\begin{array}{l}-1.31 \\
(1.02)\end{array}$ & $\begin{array}{l}-0.64 \\
(0.56)\end{array}$ & $\begin{array}{l}-1.16 \\
(1.08)\end{array}$ & $\begin{array}{l}-2.44 \\
(3.93)\end{array}$ & $\begin{array}{c}-7.29 \\
(28.43)\end{array}$ & $\begin{array}{l}-0.99 \\
(1.02)\end{array}$ & $\begin{array}{c}-6.68 \\
(30.44)\end{array}$ \\
\hline Number of Observations & & & 44 & 18 & 32 & 16 & 44 & 18 & 32 & 16 \\
\hline
\end{tabular}

Standard errors are in parentheses. All Panels are cross-sectional regressions with one observation per country. In all Panels the dependent variable is the volatility of annual growth rate of GDP per capita from 1970 to 1997, from the World Bank. Log average inflation (in Panel A) is the log of average annual inflation in the Consumer Price Index from 1970 to 1997, from the World Bank. In columns 5, 6, 9 and 10, log average inflation is instrumented using its lagged value (i.e., log average inflation over 1960-69).

Government Consumption (Panel B) is the average of the ratio of real government "consumption" expenditure to real GDP from 1970 to 1989, from Barro-Lee. In columns 5, 6, 9 and 10, government consumption is instrumented using its lagged value (i.e., government consumption 1960-69 for government consumption 1970-89). Real Exchange Rate Overvaluation (Panel C) is an index of real overvaluation of the official exchange rate during 1960-98, constructed by Easterly and Levine (2002) using the methodology of Dollar (1992). In columns 5, 6, 9 and 10, the real exchange rate overvaluation measure is instrumented using its lagged value (i.e., real overvaluation 1960-69 for real overvaluation 1970-98). Log initial GDP per capita is the Summers Heston estimate for 1970, from Barro and Lee (1993).

"Constraint on the Executive in 1970" is constraint on executive in 1970 from the Polity dataset. In all panels we instrument for institutions using log settler mortality (where mortality is per 1000 with replacement). The Excolonies Sample includes all former colonies of European Powers for which Acemoglu, Johnson and Robinson (2001) report data. The alternative sample is excolonies above median world income in 1970, using the Summers-Heston estimates from Barro and Lee (1993), and without Gabon. For more detailed data definitions and sources see Appendix Table 1. 
Table A4

Worst Output Performance, Institutions in 1970 and the Three Macroeconomic Variables

\begin{tabular}{|c|c|c|c|c|c|c|c|c|c|c|}
\hline & \multicolumn{10}{|c|}{ Dependent Variable is largest annual drop in real GDP per capita between 1970 and 1997} \\
\hline & $\begin{array}{l}\text { Excolonies } \\
\text { Sample } \\
(1)\end{array}$ & $\begin{array}{c}\text { Excolonies } \\
\text { above median } \\
\text { world income } \\
\text { (2) }\end{array}$ & $\begin{array}{c}\text { Excolonies } \\
\text { Sample } \\
(3)\end{array}$ & $\begin{array}{c}\text { Excolonies } \\
\text { above median } \\
\text { world income } \\
\text { (4) }\end{array}$ & $\begin{array}{c}\text { Excolonies } \\
\text { Sample } \\
(5)\end{array}$ & $\begin{array}{c}\text { Excolonies } \\
\text { above median } \\
\text { world income } \\
\text { (6) }\end{array}$ & $\begin{array}{c}\text { Excolonies } \\
\text { Sample } \\
\text { (7) }\end{array}$ & $\begin{array}{l}\text { Excolonies } \\
\text { above } \\
\text { median world } \\
\text { income } \\
\text { (8) }\end{array}$ & $\begin{array}{c}\text { Excolonies } \\
\text { Sample } \\
(9)\end{array}$ & $\begin{array}{c}\text { Excolonies } \\
\text { above median } \\
\text { world income } \\
\text { (10) }\end{array}$ \\
\hline & \multicolumn{2}{|c|}{ Cross-section, 1970-1997 } & \multicolumn{4}{|c|}{$\begin{array}{l}\text { Cross-section, 1970-1997, without controlling for initial } \\
\text { income }\end{array}$} & \multicolumn{4}{|c|}{$\begin{array}{c}\text { Cross-section, 1970-1997, controlling for initial } \\
\text { income }\end{array}$} \\
\hline & \multicolumn{2}{|c|}{ Institutions only } & \multicolumn{2}{|c|}{$\begin{array}{l}\text { Macro and Institutions; } \\
\text { instrumenting for institutions }\end{array}$} & \multicolumn{2}{|c|}{$\begin{array}{l}\text { Macro and Institutions; } \\
\text { instrumenting for both }\end{array}$} & \multicolumn{2}{|c|}{$\begin{array}{l}\text { Macro and Institutions; } \\
\text { instrumenting for institutions }\end{array}$} & \multicolumn{2}{|c|}{$\begin{array}{l}\text { Macro and Institutions; } \\
\text { instrumenting for both }\end{array}$} \\
\hline & \multicolumn{10}{|c|}{ Panel A: Macroeconomic Variable is Government Consumption } \\
\hline Government Consumption & & & $\begin{array}{c}2.29 \\
(14.67)\end{array}$ & $\begin{array}{c}8.75 \\
(22.54)\end{array}$ & $\begin{array}{l}-21.75 \\
(23.14)\end{array}$ & $\begin{array}{l}-42.87 \\
(49.10)\end{array}$ & $\begin{array}{c}20.18 \\
(24.12)\end{array}$ & $\begin{array}{c}46.31 \\
(51.41)\end{array}$ & $\begin{array}{c}-3.09 \\
(31.97)\end{array}$ & $\begin{array}{l}-46.90 \\
(80.32)\end{array}$ \\
\hline Log Initial GDP per capita & & & & & & & $\begin{array}{c}5.96 \\
(4.68)\end{array}$ & $\begin{array}{c}15.77 \\
(16.98)\end{array}$ & $\begin{array}{c}4.90 \\
(4.74)\end{array}$ & $\begin{array}{c}13.44 \\
(18.57)\end{array}$ \\
\hline Constraint on the Executive in 1970 & $\begin{array}{l}-2.56 \\
(0.87)\end{array}$ & $\begin{array}{l}-3.06 \\
(1.61)\end{array}$ & $\begin{array}{l}-2.42 \\
(0.83)\end{array}$ & $\begin{array}{l}-2.81 \\
(1.32)\end{array}$ & $\begin{array}{l}-2.95 \\
(1.13)\end{array}$ & $\begin{array}{l}-3.69 \\
(2.41)\end{array}$ & $\begin{array}{l}-5.35 \\
(3.24)\end{array}$ & $\begin{array}{l}-6.62 \\
(6.32)\end{array}$ & $\begin{array}{l}-5.38 \\
(3.39)\end{array}$ & $\begin{array}{l}-7.38 \\
(8.14)\end{array}$ \\
\hline Number of Observations & 61 & 24 & 61 & 24 & 60 & 24 & 61 & 24 & 60 & 24 \\
\hline & \multicolumn{10}{|c|}{ Panel B: Macroeconomic Variable is Log Average Inflation } \\
\hline Log Average Inflation & & & $\begin{array}{c}0.24 \\
(0.72)\end{array}$ & $\begin{array}{c}0.49 \\
(1.47)\end{array}$ & $\begin{array}{l}-1.38 \\
(1.78)\end{array}$ & $\begin{array}{c}0.79 \\
(1.82)\end{array}$ & $\begin{array}{l}-0.90 \\
(1.67)\end{array}$ & $\begin{array}{l}-1.92 \\
(7.97)\end{array}$ & $\begin{array}{l}-1.60 \\
(3.20)\end{array}$ & $\begin{array}{l}-0.91 \\
(8.78)\end{array}$ \\
\hline Log Initial GDP per capita & $\begin{array}{c}5.28 \\
(4.54)\end{array}$ & $\begin{array}{c}14.61 \\
(17.17)\end{array}$ & & & & & $\begin{array}{c}5.86 \\
(5.50)\end{array}$ & $\begin{array}{c}20.74 \\
(45.29)\end{array}$ & $\begin{array}{c}7.57 \\
(6.64)\end{array}$ & $\begin{array}{c}25.70 \\
(64.21)\end{array}$ \\
\hline Constraint on the Executive in 1970 & $\begin{array}{l}-5.35 \\
(3.24)\end{array}$ & $\begin{array}{l}-7.00 \\
(6.82)\end{array}$ & $\begin{array}{l}-2.56 \\
(0.88)\end{array}$ & $\begin{array}{l}-2.73 \\
(2.07)\end{array}$ & $\begin{array}{l}-3.30 \\
(1.10)\end{array}$ & $\begin{array}{l}-2.90 \\
(2.39)\end{array}$ & $\begin{array}{l}-5.67 \\
(3.82)\end{array}$ & $\begin{array}{l}-9.92 \\
(20.10)\end{array}$ & $\begin{array}{l}-7.26 \\
(4.81)\end{array}$ & $\begin{array}{l}-12.45 \\
(30.66)\end{array}$ \\
\hline Number of Observations & 61 & 24 & 61 & 24 & 49 & 20 & 61 & 24 & 48 & 19 \\
\hline & \multicolumn{10}{|c|}{ Panel C: Macroeconomic Variable is Overvaluation of Real Exchange Rate } \\
\hline Real Exchange Rate Overvaluation & & & $\begin{array}{l}-0.028 \\
(0.06)\end{array}$ & $\begin{array}{l}-0.064 \\
(0.16)\end{array}$ & $\begin{array}{l}0.017 \\
(0.12)\end{array}$ & $\begin{array}{c}0.21 \\
(0.31)\end{array}$ & $\begin{array}{l}-0.17 \\
(0.39)\end{array}$ & $\begin{array}{l}-0.897 \\
(3.910)\end{array}$ & $\begin{array}{c}0.09 \\
(0.13)\end{array}$ & $\begin{array}{c}0.10 \\
(1.66)\end{array}$ \\
\hline Log Initial GDP per capita & & & & & & & $\begin{array}{c}12.08 \\
(20.40)\end{array}$ & $\begin{array}{c}49.77 \\
(200.22)\end{array}$ & $\begin{array}{c}6.50 \\
(4.95)\end{array}$ & $\begin{array}{c}45.43 \\
(212.81)\end{array}$ \\
\hline Constraint on the Executive in 1970 & & & $\begin{array}{l}-3.03 \\
(1.72)\end{array}$ & $\begin{array}{l}-3.98 \\
(3.12)\end{array}$ & $\begin{array}{l}-2.04 \\
(1.82)\end{array}$ & $\begin{array}{l}-3.55 \\
(3.26)\end{array}$ & $\begin{array}{l}-12.07 \\
(19.52)\end{array}$ & $\begin{array}{l}-23.06 \\
(90.04)\end{array}$ & $\begin{array}{l}-3.46 \\
(3.48)\end{array}$ & $\begin{array}{l}-21.38 \\
(96.54)\end{array}$ \\
\hline Number of Observations & & & 44 & 18 & 32 & 16 & 44 & 18 & 32 & 16 \\
\hline
\end{tabular}

Standard errors are in parentheses. All Panels are cross-sectional regressions with one observation per country. In all Panels the dependent variable is the lowest annual growth rate of GDP per capita from 1970 to 1997 (with the sign changed so that an output fall is a positive number), from the World Bank. Log average inflation (in Panel A) is the log of average annual inflation in the Consumer Price Index from 1970 to 1997, from the World Bank. In columns 5, 6, 9 and 10, log average inflation is instrumented using its lagged value (i.e., log average inflation over 1960-69).

Government Consumption (Panel B) is the average of the ratio of real government "consumption" expenditure to real GDP from 1970 to 1989, from Barro-Lee. In columns 5, 6, 9 and 10, government consumption is instrumented using its lagged value (i.e., government consumption 1960-69 for government consumption 1970-89). Real Exchange Rate Overvaluation (Panel C) is an index of real overvaluation of the official exchange rate during 1960-98, constructed by Easterly and Levine (2002) using the methodology of Dollar (1992). In columns 5, 6, 9 and 10, the real exchange rate overvaluation measure is instrumented using its lagged value (i.e., real overvaluation 1960-69 for real overvaluation 1970-98). Log initial GDP per capita is the Summers Heston estimate for 1970, from Barro and Lee (1993).

"Constraint on the Executive in 1970" is constraint on executive in 1970 from the Polity dataset. In all panels we instrument for institutions using log settler mortality (where mortality is per 1000 with replacement). The Excolonies Sample includes all former colonies of European Powers for which Acemoglu, Johnson and Robinson (2001) report data. The alternative sample is excolonies above median world income in 1970, using the Summers-Heston estimates from Barro and Lee (1993), and without Gabon. For more detailed data definitions and sources see Appendix Table 1 . 
Table A5

Growth, Institutions in 1970 and the Three Macroeconomic Variables

Dependent Variable is average annual growth of real GDP per capita between 1970 and 1997

\begin{tabular}{|c|c|c|c|c|c|c|c|c|c|c|}
\hline & $\begin{array}{c}\text { Excolonies } \\
\text { Sample } \\
(1) \\
\end{array}$ & $\begin{array}{c}\text { Excolonies } \\
\text { above median } \\
\text { world income } \\
(2)\end{array}$ & $\begin{array}{c}\text { Excolonies } \\
\text { Sample } \\
(3) \\
\end{array}$ & $\begin{array}{c}\text { Excolonies } \\
\text { above median } \\
\text { world income } \\
\text { (4) } \\
\end{array}$ & $\begin{array}{c}\text { Excolonies } \\
\text { Sample } \\
(5) \\
\end{array}$ & $\begin{array}{c}\text { Excolonies } \\
\text { above median } \\
\text { world income } \\
(6)\end{array}$ & $\begin{array}{c}\text { Excolonies } \\
\text { Sample } \\
(7) \\
\end{array}$ & $\begin{array}{c}\text { Excolonies } \\
\text { above } \\
\text { median world } \\
\text { income } \\
(8) \\
\end{array}$ & $\begin{array}{c}\text { Excolonies } \\
\text { Sample } \\
(9) \\
\end{array}$ & $\begin{array}{c}\text { Excolonies } \\
\text { above median } \\
\text { world income } \\
(10) \\
\end{array}$ \\
\hline & \multicolumn{2}{|c|}{ Cross-section, $1970-1997$} & \multicolumn{4}{|c|}{$\begin{array}{l}\text { Cross-section, 1970-1997, without controlling for initial } \\
\text { income }\end{array}$} & \multicolumn{4}{|c|}{$\begin{array}{l}\text { Cross-section, 1970-1997, controlling for initial } \\
\text { income }\end{array}$} \\
\hline & \multicolumn{2}{|c|}{ Institutions only } & \multicolumn{2}{|c|}{$\begin{array}{c}\text { Macro and Institutions; } \\
\text { instrumenting for institutions }\end{array}$} & \multicolumn{2}{|c|}{$\begin{array}{l}\text { Macro and Institutions; } \\
\text { instrumenting for both }\end{array}$} & \multicolumn{2}{|c|}{$\begin{array}{c}\text { Macro and Institutions; } \\
\text { instrumenting for institutions }\end{array}$} & \multicolumn{2}{|c|}{$\begin{array}{l}\text { Macro and Institutions; } \\
\text { instrumenting for both }\end{array}$} \\
\hline & \multicolumn{10}{|c|}{ Panel A: Macroeconomic Variable is Government Consumption } \\
\hline Government Consumption & & & $\begin{array}{l}-1.31 \\
(5.06)\end{array}$ & $\begin{array}{l}-2.93 \\
(7.86)\end{array}$ & $\begin{array}{c}1.45 \\
(6.86)\end{array}$ & $\begin{array}{c}7.44 \\
(13.03)\end{array}$ & $\begin{array}{l}-6.35 \\
(8.31)\end{array}$ & $\begin{array}{l}-13.27 \\
(15.19)\end{array}$ & $\begin{array}{l}-1.97 \\
(10.87)\end{array}$ & $\begin{array}{c}8.74 \\
(22.70)\end{array}$ \\
\hline Log Initial GDP per capita & & & & & & & $\begin{array}{l}-2.08 \\
(1.61)\end{array}$ & $\begin{array}{l}-4.86 \\
(5.02)\end{array}$ & $\begin{array}{l}-1.95 \\
(1.61)\end{array}$ & $\begin{array}{l}-4.31 \\
(5.25)\end{array}$ \\
\hline Constraint on the Executive in 1970 & $\begin{array}{c}0.80 \\
(0.28)\end{array}$ & $\begin{array}{c}0.63 \\
(0.47)\end{array}$ & $\begin{array}{c}0.77 \\
(0.30)\end{array}$ & $\begin{array}{c}0.59 \\
(0.48)\end{array}$ & $\begin{array}{c}0.82 \\
(0.33)\end{array}$ & $\begin{array}{c}0.74 \\
(0.64)\end{array}$ & $\begin{array}{c}1.78 \\
(1.12)\end{array}$ & $\begin{array}{c}1.75 \\
(1.87)\end{array}$ & $\begin{array}{c}1.79 \\
(1.15)\end{array}$ & $\begin{array}{c}1.93 \\
(2.30)\end{array}$ \\
\hline \multirow[t]{2}{*}{ Number of Observations } & 61 & 24 & 61 & 24 & 60 & 24 & 61 & 24 & 60 & 24 \\
\hline & \multicolumn{10}{|c|}{ Panel B: Macroeconomic Variable is Log Average Inflation } \\
\hline Log Average Inflation & & & $\begin{array}{l}-0.20 \\
(0.23)\end{array}$ & $\begin{array}{l}-0.15 \\
(0.42)\end{array}$ & $\begin{array}{c}0.37 \\
(0.60)\end{array}$ & $\begin{array}{l}-0.16 \\
(0.63)\end{array}$ & $\begin{array}{c}0.19 \\
(0.57)\end{array}$ & $\begin{array}{l}0.60 \\
(2.39)\end{array}$ & $\begin{array}{c}0.42 \\
(0.99)\end{array}$ & $\begin{array}{c}0.37 \\
(2.75)\end{array}$ \\
\hline Log Initial GDP per capita & $\begin{array}{l}-1.86 \\
(1.56)\end{array}$ & $\begin{array}{l}-4.53 \\
(5.06)\end{array}$ & & & & & $\begin{array}{l}-1.98 \\
(1.87)\end{array}$ & $\begin{array}{c}-6.46 \\
(13.58)\end{array}$ & $\begin{array}{l}-2.13 \\
(2.05)\end{array}$ & $\begin{array}{c}-7.98 \\
(20.08)\end{array}$ \\
\hline Constraint on the Executive in 1970 & $\begin{array}{c}1.78 \\
(1.11)\end{array}$ & $\begin{array}{l}1.85 \\
(2.01)\end{array}$ & $\begin{array}{c}0.79 \\
(0.28)\end{array}$ & $\begin{array}{c}0.54 \\
(0.60)\end{array}$ & $\begin{array}{c}0.89 \\
(0.37)\end{array}$ & $\begin{array}{c}0.57 \\
(0.83)\end{array}$ & $\begin{array}{c}1.85 \\
(1.30)\end{array}$ & $\begin{array}{c}2.78 \\
(6.03)\end{array}$ & $\begin{array}{c}1.98 \\
(1.48)\end{array}$ & $\begin{array}{c}3.52 \\
(9.58)\end{array}$ \\
\hline Number of Observations & 61 & 24 & 61 & 24 & 49 & 20 & 61 & 24 & 48 & 19 \\
\hline \multicolumn{11}{|c|}{ Panel C: Macroeconomic Variable is Overvaluation of Real Exchange Rate } \\
\hline Real Exchange Rate Overvaluation & & & $\begin{array}{l}0.0051 \\
(0.02)\end{array}$ & $\begin{array}{c}0.0029 \\
(0.05)\end{array}$ & $\begin{array}{l}0.017 \\
(0.05)\end{array}$ & $\begin{array}{c}0.01 \\
(1.05)\end{array}$ & $\begin{array}{c}0.053 \\
(0.130)\end{array}$ & $\begin{array}{c}0.250 \\
(1.130)\end{array}$ & $\begin{array}{l}-0.01 \\
(0.05)\end{array}$ & $\begin{array}{c}0.05 \\
(0.62)\end{array}$ \\
\hline Log Initial GDP per capita & & & & & & & $\begin{array}{l}-4.11 \\
(7.00)\end{array}$ & $\begin{array}{l}-14.52 \\
(57.67)\end{array}$ & $\begin{array}{l}-1.95 \\
(1.74)\end{array}$ & $\begin{array}{l}-17.60 \\
(79.21)\end{array}$ \\
\hline Constraint on the Executive in 1970 & & & $\begin{array}{c}0.89 \\
(0.61)\end{array}$ & $\begin{array}{c}0.68 \\
(0.94)\end{array}$ & $\begin{array}{c}0.68 \\
(0.75)\end{array}$ & $\begin{array}{c}0.79 \\
(1.10)\end{array}$ & $\begin{array}{c}3.96 \\
(6.69)\end{array}$ & $\begin{array}{c}6.24 \\
(25.93)\end{array}$ & $\begin{array}{c}1.11 \\
(1.23)\end{array}$ & $\begin{array}{c}7.70 \\
(35.93)\end{array}$ \\
\hline Number of Observations & & & 44 & 18 & 32 & 16 & 44 & 18 & 32 & 16 \\
\hline
\end{tabular}

Standard errors are in parentheses. All Panels are cross-sectional regressions with one observation per country. In all Panels the dependent variable is the average annual growth rate of GDP per capita from 1970 to 1997, from the World Bank. Log average inflation (in Panel A) is the log of average annual inflation in the Consumer Price Index from 1970 to 1997, from the World Bank. In columns 5, 6, 9 and 10, log average inflation is instrumented using its lagged value (i.e., log average inflation over 1960-69).

Government Consumption (Panel B) is the average of the ratio of real government "consumption" expenditure to real GDP from 1970 to 1989 , from Barro-Lee. In columns 5, 6, 9 and 10, government consumption is instrumented using its lagged value (i.e., government consumption 1960-69 for government consumption 1970-89). Real Exchange Rate Overvaluation (Panel C) is an index of real overvaluation of the official exchange rate during 1960-98, constructed by Easterly and Levine (2002) using the methodology of Dollar (1992). In columns 5, 6, 9 and 10, the real exchange rate overvaluation measure is instrumented using its lagged value (i.e., real overvaluation 1960-69 for real overvaluation 1970-98). Log initial GDP per capita is the Summers Heston estimate for 1970, from Barro and Lee (1993).

"Constraint on the Executive in 1970" is constraint on executive in 1970 from the Polity dataset. In all panels we instrument for institutions using log settler mortality (where mortality is per 1000 with replacement). The Excolonies Sample includes all former colonies of European Powers for which Acemoglu, Johnson and Robinson (2001) report data. The alternative sample is excolonies above median world income in 1970, using the Summers-Heston estimates from Barro and Lee (1993), and without Gabon. For more detailed data definitions and sources see Appendix Table 1. 


\section{Figure 1A}

\section{Standard deviation of growth rate, 1970-97, against $\log$ settler mortality}

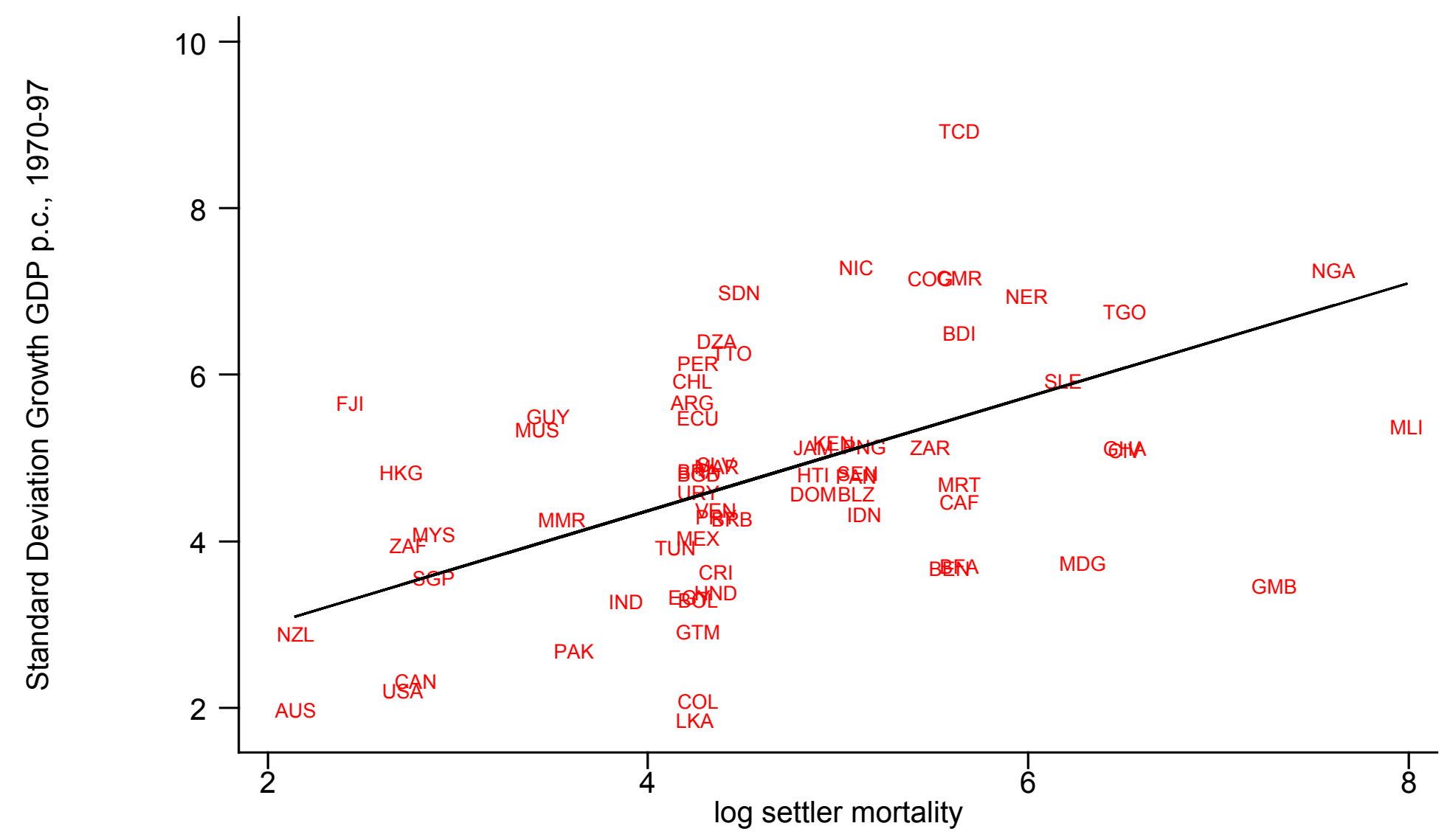




\section{Figure 1B}

\section{Worst output drop, 1970-97, against log settler mortality}

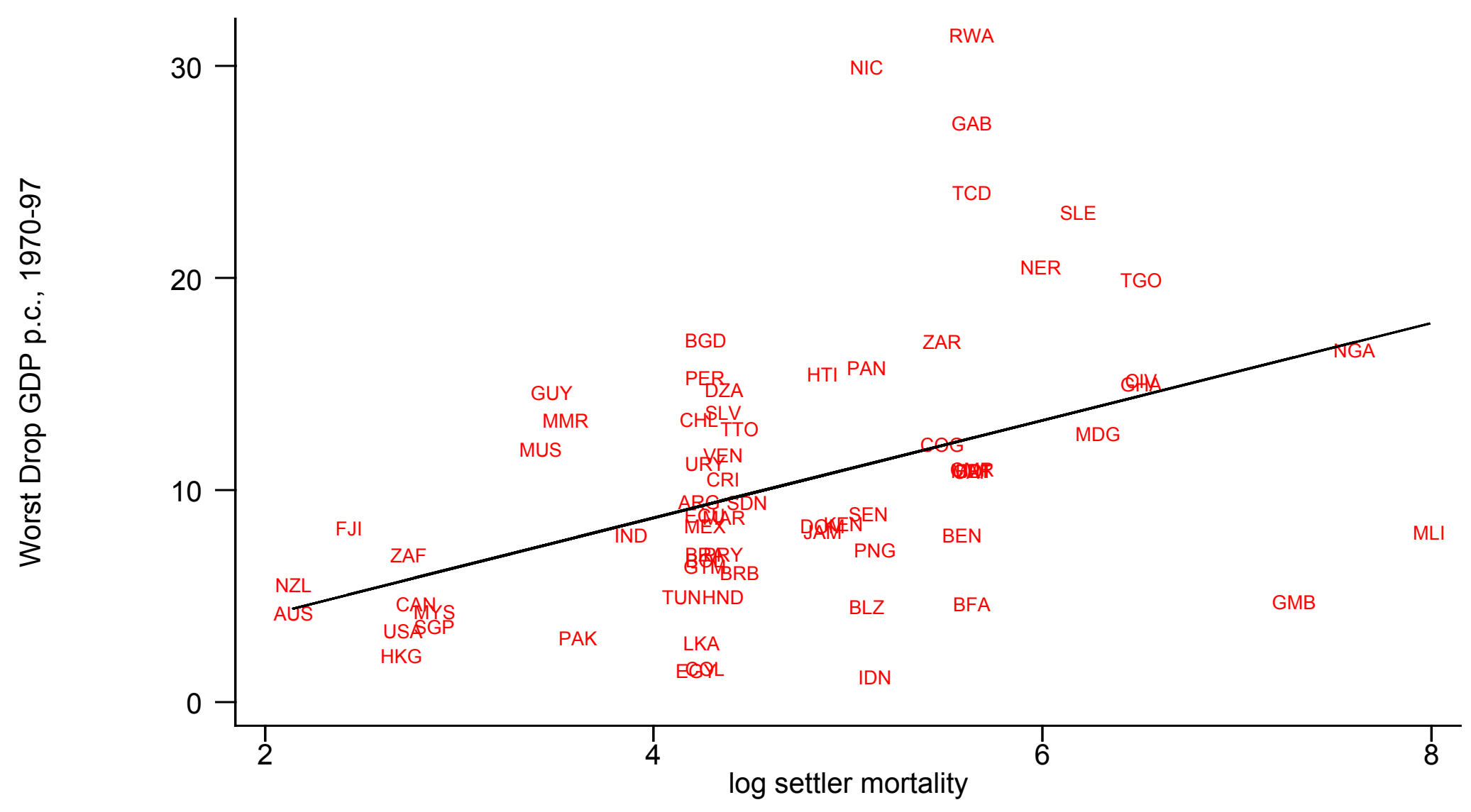




\section{Figure 1C}

\section{GDP per capita growth rate, 1970-97, against log settler mortality}

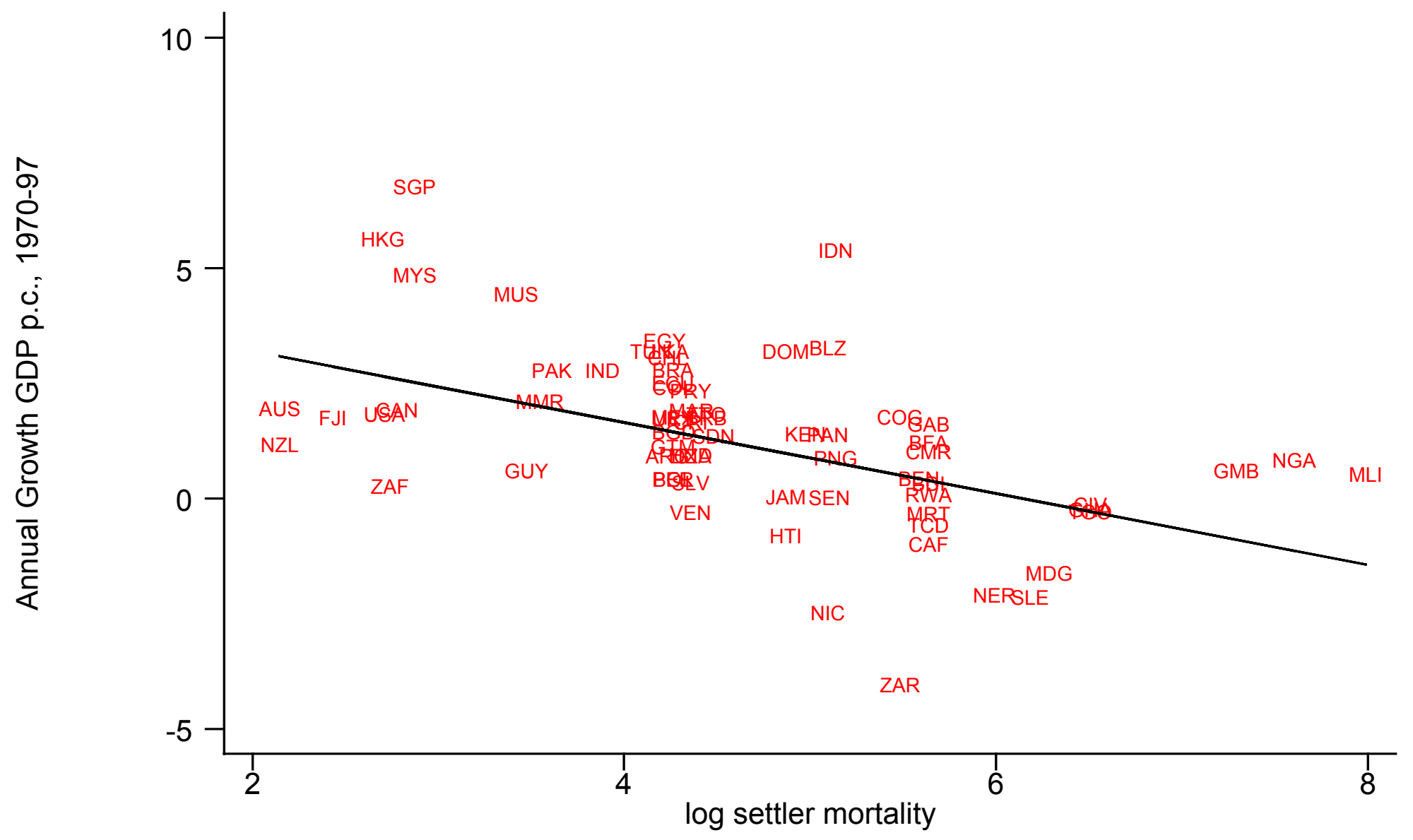




\section{Figure 2 Volatility and Three Macro Variables}
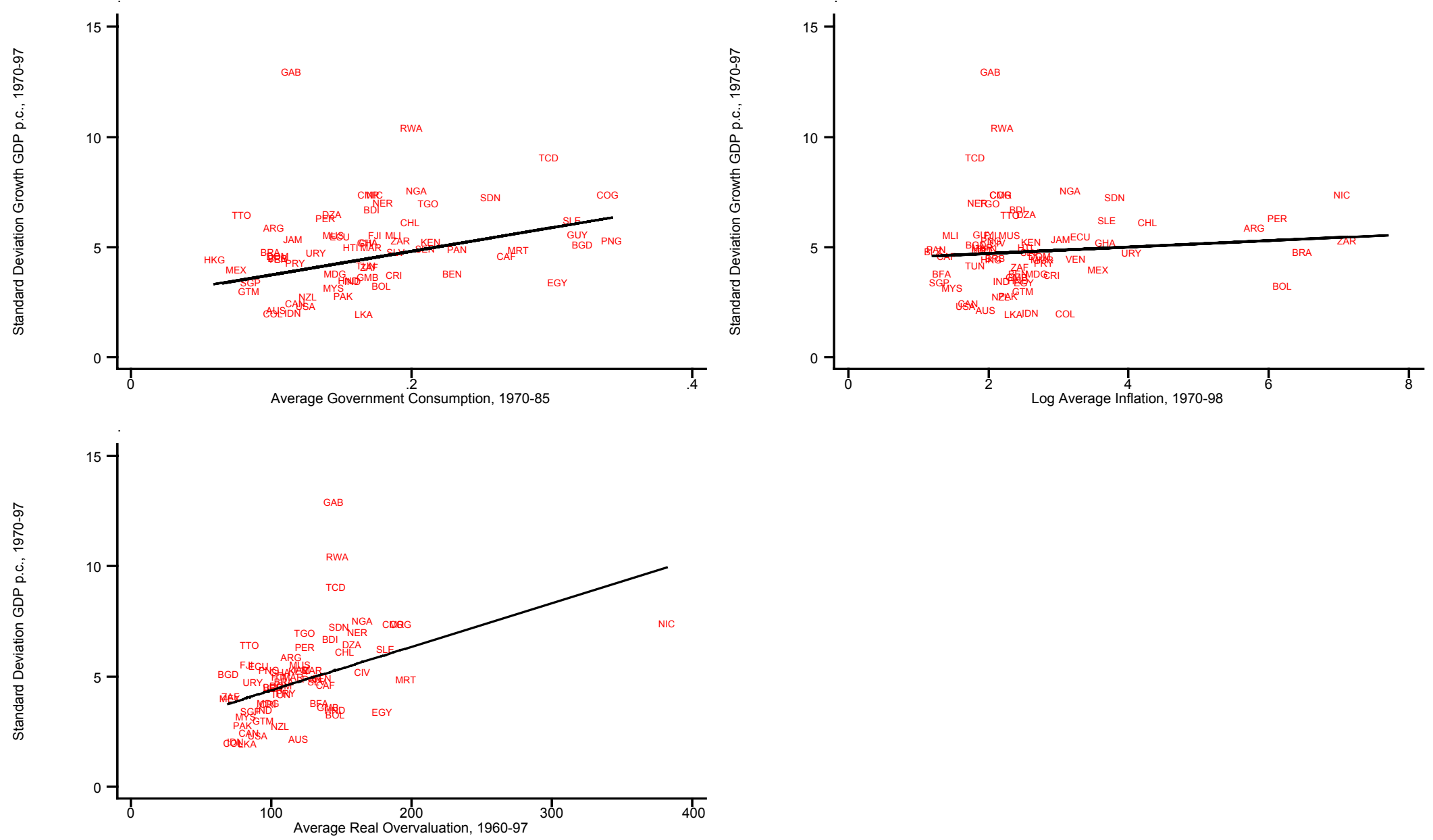


\section{Figure 3}

Worst Output Drop and Three Macro Variables
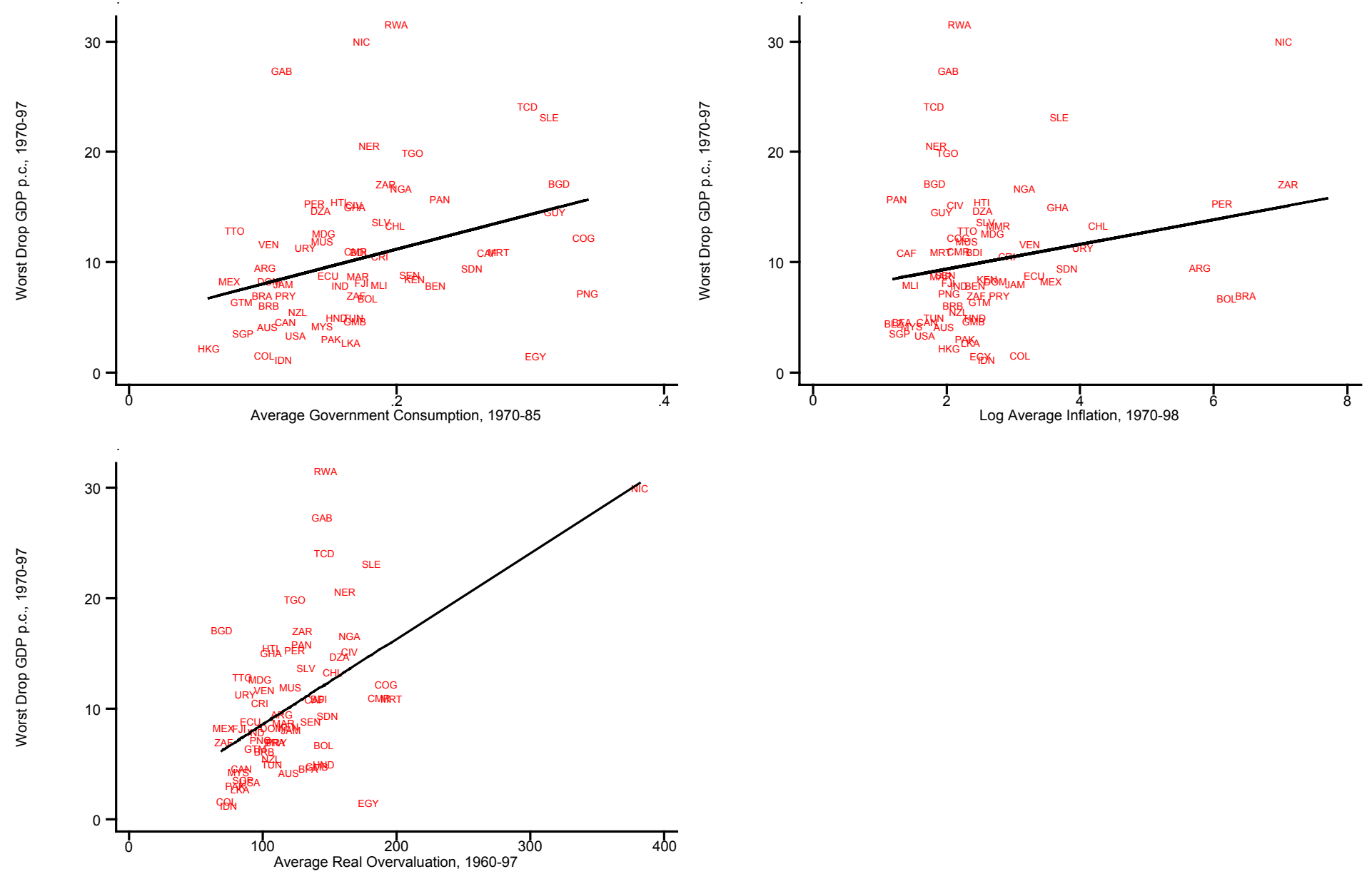


\section{Figure 4}

\section{Growth and Three Macro Variables}
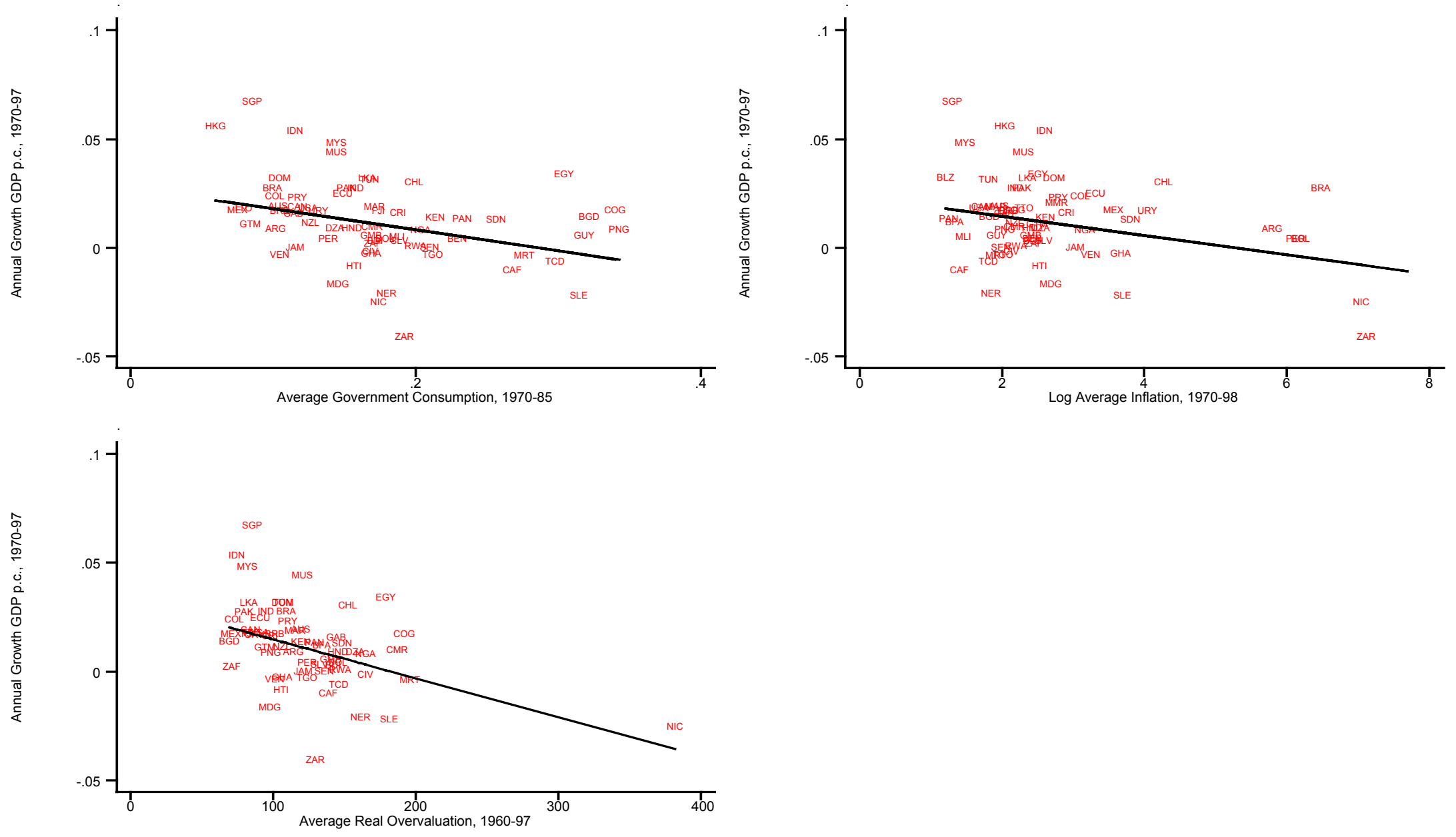


\section{Figure 5}

Average constraint on executive (1950, 1960, 1970) vs. $\log$ settler mortality

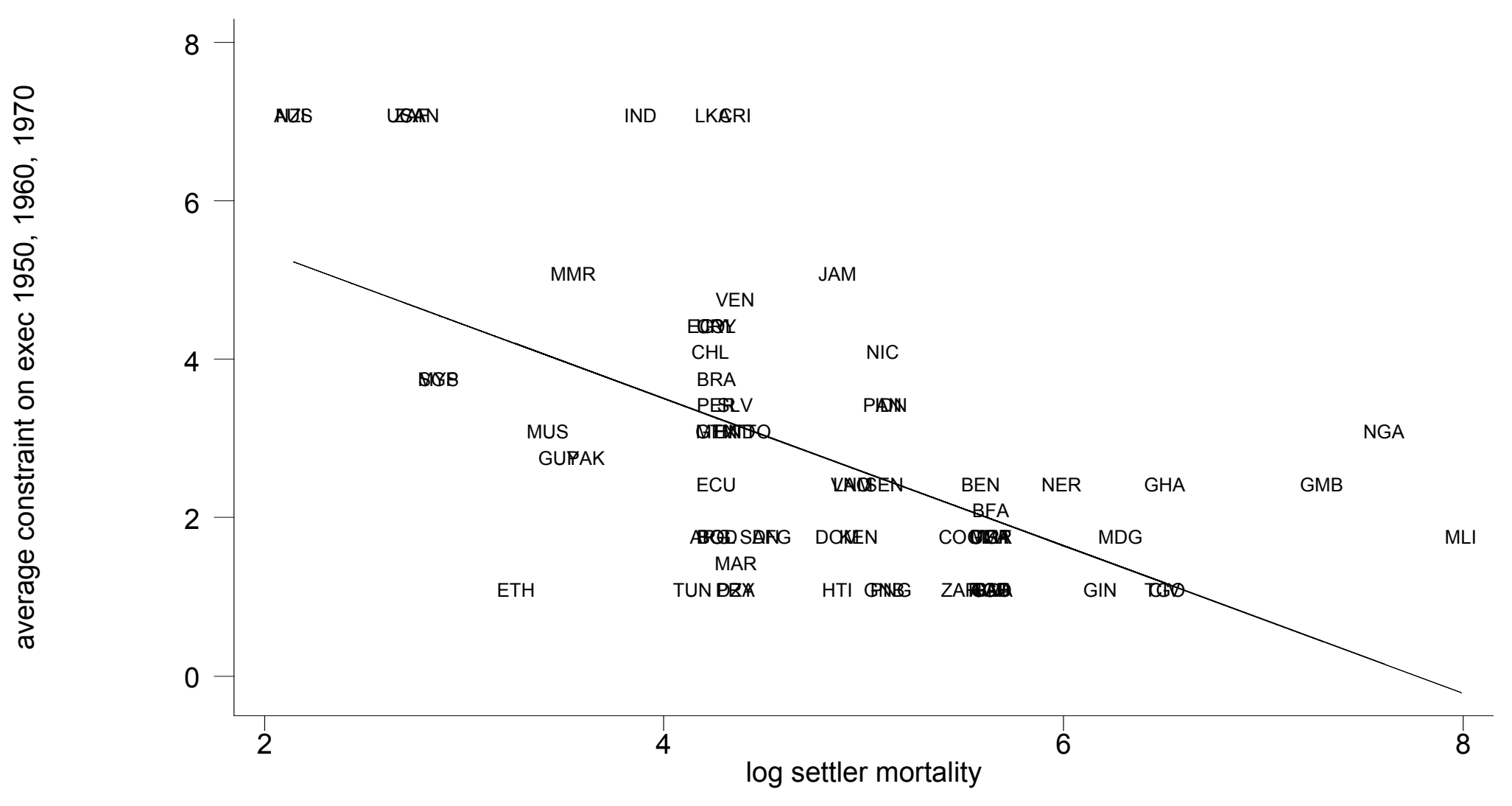

